Ks. Józef Wołczański

Kraków

\title{
Korespondencja abp. Józefa Teodorowicza z prof. Stefanem Dąbrowskim $\mathrm{z}$ lat 1921-1938
}

\section{Wprowadzenie}

Osoba prof. Stefana Dąbrowskiego (1877-1947) w okresie międzywojennym zapisała się na trwałe $\mathrm{w}$ polskiej historii w kilku obszarach życia publicznego: medycyny, polityki, szkolnictwa wyższego oraz Kościoła katolickiego. Urodził się 31 I 1877 r. w inteligenckiej rodzinie warszawskiej. Po ukończeniu gimnazjum odbył studia na Wydziale Lekarskim Uniwersytetu Warszawskiego (1895-1900). Zaangażował się wówczas w działalność ruchu patriotyczno-młodzieżowego. W latach 1900-1902 kontynuował studia na Wydziale Medycznym Sorbony w Paryżu. Po powrocie do kraju związał się od roku 1903 z Wydziałem Lekarskim Uniwersytetu Lwowskiego, rozpoczynając karierę uniwersytecką od stanowiska demonstratora w Zakładzie Farmakologii i Farmakognozji, poprzez asystenturę w Zakładzie Chemii Lekarskiej, habilitację i docenturę. W latach 1908-1911 ponownie pogłębiał studia w Paryżu. W listopadzie 1911 r. został mianowany profesorem nadzwyczajnym fizjologii i nauki żywienia zwierząt domowych i mleczarstwa Akademii Rolniczej w Dublanach k. Lwowa. Od roku 1913 do 1918 pełnił obowiązki profesora chemii i fizjologii żywienia Akademii Weterynaryjnej we Lwowie. W latach 1919-1920 jako profesor zwyczajny chemii ogólnej i nauki żywienia zwierząt nadal pracował w Akademii Weterynaryjnej we Lwowie ${ }^{1}$.

W środowisku lwowskim prof. Dąbrowski współpracował z Ligą Narodową, a później ze Zjednoczeniem Narodowym, utrzymując bliskie relacje m.in. z abp. Józefem Teodorowiczem i bp. Adamem Stefanem Sapiehą. Uczestniczył też w obronie Lwowa podczas wojny ukraińsko-polskiej 1918-1919. Od kwietnia 1920 do jesieni 1921 pełnił funkcję wiceministra spraw zagranicznych. Piastował mandat poselski w latach 1922-1935 z ramienia Związku Ludowo-Narodowego, natomiast w latach 1928-1935 był wiceprezesem Stronnictwa Narodowego ${ }^{2}$.

Po zakończeniu kariery dyplomatycznej, prof. Dąbrowski nie powrócił do Lwowa, ale w 1921 r. przyjął angaż na Uniwersytecie Poznańskim; został tam kierownikiem Zakładu Chemii Fizjologicznej na Wydziale Lekarskim. Na gruncie poznańskim kontynuował badania zapoczątkowane we Lwowie. Interesował się funkcjami nerek, prowadził analizy składników moczu i krwi opracowując nowe metody badawcze na tym polu.

\footnotetext{
${ }^{1}$ J. Malinowski, Stefan Dąbrowski (1877-1947). Biografia polityczna, Poznań 2014, s. 10-103.

2 Tamże, s. 29-140, 147-253.
} 
Ponadto miał wykłady z zakresu chemii fizjologicznej, specjalną uwagę poświęcając kwestii składników tkanki i osocza oraz chemicznym zasadom funkcji oddechowych i wydalniczych. Był autorem licznych prac naukowych oraz członkiem wielu towarzystw i organizacji medycznych tak krajowych, jak i zagranicznych. Poza pracą naukowo-badawczą angażował się w sferę administracji uczelni; w latach 1937/38 - 1938/39 pełnił obowiązki dziekanaWydziału Lekarskiego. Jednocześnie patronował stowarzyszeniom i organizacjom studenckim, m.in. Młodzieży Wszechpolskiej. Wiosną $1939 \mathrm{r}$. został wybrany rektorem uczelni na lata 1939/40 i 1940/413. Okres II wojny światowej spędził razem z rodziną w Szczawnicy, Nawojowej, Ropie k. Gorlic, Dobrej, Krakowie, Bielicach k. Sochaczewa, Wikowicach k. Rawy Mazowieckiej, skąd powrócił do Poznania wiosną $1945 \mathrm{r}$. Ministerstwo Oświaty powierzyło mu wówczas ponownie urząd rektora Uniwersytetu Poznańskiego. Wskutek rozpętanej przez czynniki państwowo-partyjne nagonki na rektora inspirowane jego światopoglądem chrześcijańskim, udał się na urlop od 1 V 1946 r. do końca bieżącego roku akademickiego 1946/47 stanowiącego zarazem finał kadencji rektorskiej. Zmarł 23 III 1947 r. w Poznaniu

Wspomniano już wyżej o bliskich relacjach łączących prof. Stefana Dąbrowskiego z Kościołem katolickim i jego hierarchami, w tym z ormiańskim arcybiskupem lwowskim Józefem Teodorowiczem. Opierały się one o jasno wyskrystalizowany system wartości chrześcijańskich i narodowych, jakie wyznawał poznański uczony, dając temu wyraz na forum publicznym. Nic więc dziwnego, iż listy kursujące pomiędzy obu wspomnianymi postaciami zawierały nie tyle zdawkowe informacje z bieżącego życia naukowego i społeczno-politycznego, ale nade wszystko pełniły rolę swoistych konsultacji, sugestii, czy wręcz dyrektyw do realizacji idei wysuwanych najczęściej przez lwowskiego hierarchę. $Z$ biegiem lat tematyka korespondencji została zdominowana przez kwestie medyczno-fizjologiczne związane z pisanymi wówczas przez abp. Teodorowicza pracami poświęconymi fenomenowi Teresy Neumann. Prof. Dąbrowski stał się wówczas dla arcybiskupa najważniejszym autorytetem krajowym w procesie właściwej interpretacji niezwykłych zjawisk, jakie miały miejsce w Konnersreuth. Trzeba przyznać, iż hierarcha w trosce o rzetelność swoich wywodów chętnie i często korzystał z fachowych rad profesora, choć niekiedy usiłował nakłonić go do poparcia własnego punktu widzenia, niekoniecznie poprawnego. Prof. Dąbrowski darzył ormiańskiego hierarchę niesłychaną estymą, ten zaś odwzajemniał mu się niekłamaną przyjaźnią.

Prezentowane niżej źródła to zapewne niewielka część bogatej korespondencji zachowana do naszych czasów. Tworzą ją 41 listów lwowskiego hierarchy i 26 poznańskiego uczonego. Pochodzą one z zasobów Archiwum Fundacji Kultury i Dziedzictwa Ormian Polskich w Warszawie, Archiwum Biblioteki Kórnickiej w Poznaniu oraz Archiwum Polskiej Akademii Nauk w Poznaniu. Za uprzejme udostępnienie materiałów, wydawca składa niniejszym pracownikom owym dwóch ostatnich instytucji szczere podziękowanie.

3 Tamże, s. 253-263.

4 Tamże, s. 265-294. 


\section{Dokument 1}

Oryg.: ABKP, sygn. 2738, teczka: Papiery Stefana Dąbrowskiego, Fragment listu abp. Józefa Teodorowicza do prof. Stefana Dąbrowskiego, [Rzym 1921 r.].

\section{Kochany ${ }^{\text {a }}$ Panie Wiceministrze $!^{5}$}

Mam nadzieję, że w Polsce będą zadowoleni z naszego rozwiązania sprawy szląskiejb. Niełatwe to było zadanie. Najtrudniej wyciągać coś z błota. Tylko pilnujcie Ogna ${ }^{6} \mathrm{i}$ jeśli on dotąd komentarza nie ogłosił, domagajcie się tego energicznie od niego. Fatalna to rzecz z brakiem wiadomości. Nic nie wiemy, czy została ogłoszoną nasza odezwa do społeczeństwa? Posłaliśmy ją w raz z Ks. Biskupem ${ }^{7}$ kurierem przez poselstwo. O Ogniu też nic nie wiemy. Przez ten fatalny brak informacji traci się bardzo wiele. Tu francuzi ${ }^{c}$ dają $[\ldots]^{\mathrm{d}}$.

\section{Dokument 2}

Oryg.: ABKP, sygn. 2738, teczka: Papiery Stefana Dąbrowskiego, List abp. Józefa Teodorowicza do prof. Stefana Dąbrowskiego, Rzym 11/I 1921 r.

\section{Kochany ${ }^{\mathrm{a}}$ Panie Wiceministrze!}

Do listu już napisanego przed kilkoma dniami dołączam jeszcze drugi. Oto dowiedziałem się poufnie, że z Warszawy robią nastrój w poselstwach przez telegramy i inne informacje, że $\mathrm{z}$ francją ${ }^{\mathrm{b}}$ jest źle, że wenętrzna jej sytuacja fatalna etc. etc. Jaki jest cel tej roboty to trudno doprawdy zrozumieć, chyba, że na tym zależy, ażeby przygotować opinię na wyjazd Piłsudskiego ${ }^{8}$ do Anglii i przedstawiali rzecz, że krytykującymi warunki będziemy my, a nie oni. Jakkolwiek jest, to uważam tę robotę za fałszywą i szkodliwą. Jak $[\ldots]^{c}$ twierdzi, francja postawi bardzo silne warunki militarne i ekonomiczne.

a Tekst pisany czarnym atramentem na jednej stronicy papieru formatu A4. Brak zakończenia.

${ }^{5}$ W latach 1920-1921 prof. Dąbrowski pełnił urząd wiceministra spraw zagranicznych.

b Zgodnie z oryginałem. Poprawnie: śląskiej.

${ }^{6}$ Ogno Serra Giovanni Battista - rzymskokatolicki duchowny włoski, zaangażowany jako delegat Stolicy Apostolskiej w plebiscyt na Śląsku 20 III 1921 r.

7 Aluzja do biskupa krakowskiego Adama Stefana Sapiehy.

c Zgodnie $\mathrm{z}$ oryginałem.

d Brak dalszego ciągu tekstu.

a Tekst pisany czarnym atramentem na jednej stronicy papieru formatu A4. Brak zakończenia.

b Zgodnie z oryginałem; tak konsekwentnie dalej.

${ }^{8}$ Zob. w niniejszej publikacji: J. Wołczański, Listy abp. Józefa Teodorowicza do abp. Józefa Bilczewskiego, dokument 132.

c Wyraz nieczytelny. 


\section{Dokument 3}

Oryg.: APANP, sygn. P III - 116, teczka 86, List abp. Józefa Teodorowicza do prof. Stefana Dąbrowskiego, Lwów 6 II 1925 r.

\section{Przezacny ${ }^{\mathrm{a}}$ Kochany Panie!}

Trudno mi doprawdy cokolwiek Panu pisać, kiedy sam się czuję ciosem Państwa tak bardzo zbolały ${ }^{9}$. Pamiętam to śliczne Dziecko, które jak widzę z telegramu Pana, także tak śliczną, tak już do nieba dojrzałą miało duszyczkę. Bóg zabiera i powołuje dusze wtedy do siebie, gdy dla tych dusz lepiej jest i z korzyścią większą odejść ze świata niż na nim pozostać. Bóg przewiduje u dziecka przyszłe koleje życia, które by je czekały, gdyby pozostało przy życiu. I odmierzając podług tego [... $]^{\mathrm{b}}$ jego pokuty, dla większego dobra zabiera je. Widać, że córka Pańska była już tak wewnętrznie i duchowo dojrzałą, że mogła już odejść stąd, szczęśliwsza dziś, niż gdyby była pozostała. Tylko dla Państwa biednych to cios tak bolesny i straszliwy, że tylko myśl chrześcijańska, tylko przekonanie o szczęściu tak wybranego dziecka, tylko szczególniejsza łaska przywiązana do takiego krzyża osobno może serca wasze, Przezacni Państwo, na strunie napiętej cierpienia do woli myśli i woli Bożej podnieść i dostroić. O to się dla Was gorąco modlę.

Zawsze państwu oddany w czci i przyjaźni

† Teodorowicz

Lwów, d[nia] 6/II [1]925

\section{Dokument 4}

Oryg.: APANP, sygn. P III - 116, teczka 86, List abp. Józefa Teodorowicza do prof. Stefana Dąbrowskiego, Lwów 1 III 1927 r.

Przezacny Kochany Panie Pośle!

Bardzo a bardzo Panu dziękuję za list, który tak głęboko wnika w rolę Kościoła, a niestety tak trafną zawiera ocenę sytuacji, że od „a" do "zet” na wszystko się piszę sam. Te same bowiem myśli przeżywam i te same niebezpieczeństwa dopatruję. Na szczęście nie ja sam tak widzę, ale są i inni biskupi, co również sobie zdają sprawę ze sytuacji. Będzie teraz konferencja biskupów w Warszawie i jak tam dojrzeje sprawa w umysłach, to mam nadzieję, że mi się uda konkretnie rzecz określić i przedstawić. Mam też nadzieję, że wtedy w Warszawie z Panem się [z]obaczę i rozmówię. Nie wchodzę w szczegóły, bo by trzeba napisać książkę. Kościół przechodzi w Polsce kryzys wewnętrzny, łatwo zrozumiały, ale mam nadzieję, że wyjdzie z niej ${ }^{\mathrm{b}}$ zwycięsko.

Dziękuję Panu raz jeszcze i najoddańsze wyrazy łączę

Lwów, d[nia] 1/III [1]927

† Teodorowicz

a Tekst pisany czarnym atramentem na jednej stronicy papieru formatu A4.

9 Aluzja do śmierci córki prof. Dąbrowskiego - Heleny (1912-1925).

b Wyraz nieczytelny.

a Tekst pisany czarnym atramentem na jedenej stronicy papieru formatu listowego.

b Zapis zgodny z oryginałem; poprawnie: $\mathrm{z}$ niego. 


\section{Dokument 5}

Oryg.: APANP, sygn. P III - 116, teczka 86, List abp. Józefa Teodorowicza do prof. Stefana Dąbrowskiego, Lwów 10 VII 1930 r.

$\dagger$

Kochany ${ }^{a}$ Panie Pośle!

Był u mnie Weinfeld ${ }^{10}$ i radziliśmy nad Strońskim ${ }^{11}$. Zarówno on, jak i ja niezależnie jeden od drugiego przyszliśmy do przekonania, że należy za wszelką cenę wyrwać Strońskiego z obecnej sytuacji. Pisząc 3 artykuły dziennie on jałowieje i jałowieć musi. Nawet taki talent jak jego wyczerpać się musi. Traktują go Pan wie jak. I przyszłości przed nim żadnej nie ma. Jedyny sposób na to, ażeby on powrócił do norm swojego talentu, ażeby zabezpieczył sobie przyszłość i ażeby się z nim liczono w klubie jest założenie przez niego tygodnika lub choćby tylko dwutygodnika. Jest na to doskonała chwila. Najpierw Stroński dał się poznać przez swe artykuły pisane w różnych dziennikach szerszemu ogółowi, potem upadł tygodnik $\mathrm{T}[\mathrm{h}]$ uguta $^{12}$, następnie jesień obecna przedstawia się bardzo interesująco. Musiałby Stroński obecnie wypocząć i na jesień przygotować pismo. Napiszę do niego o tym osobno. Ale kwestia główna, jak mu do tego dopomóc? Już w sierpniu należałoby zebrać sumę potrzebną. Ale jak i u kogo? Jeśli Pana przekona nasz pomysł, to Pan się niezawodnie tą sprawą najlepiej zajmie. Może byłoby najpraktyczniej zebrać jaki[chś] dwudziestu zamożniejszych, którzy by na pół roku zapewnili mu każdy z nich trzydziestu do pięćdziesięciu prenumeratorów. To by ich kosztowało jakich[ś] dwieście złotych miesięcznie. Stroński ażeby się utrzymać potrzebuje tysiąc prenumeratorów. Poddaję Panu ten projekt i na tym urywam wobec konferencji dzisiejszej.

Najserdeczniejsze pozdrowienia i najoddańsze wyrazy dla Pana łączę

† Teodorowicz

Lwów, d[nia] 10/VII [19]930

\section{Dokument 6}

Oryg.: APANP, sygn. P III - 116, teczka 86, List abp. Józefa Teodorowicza do prof. Stefana Dąbrowskiego, Marienbad 3 VIII 1930 r.

Marienbad $^{13}$, 3/VIII [19]930

Kochany ${ }^{\mathrm{a}}$ Panie Pośle!

a Tekst pisany czarnym atramentem na 1,5 stronicy papieru formatu A4.

10 Weinfeld Ignacy (1877-1939), dr prawa, 1901-1918 pracownik Prokuratorii Skarbu we Lwowie, w 1916 r. uzyskał habilitację z zakresu prawa i skarbowości na Uniwerytecie Lwowskim, 1916-1939 docent tamże, 19201922 podsekretarz w Ministerstwie Skarbu, autor podręcznika na temat polskiej skarbowości. A. Redzik, Wydziat Prawa, w: Academia militans. Uniwersytet Jana Kazimierza we Lwowie, red. A. Redzik, Kraków 2015, s. 529-530.

${ }^{11}$ Zob. w niniejszej publikacji: J. Wołczański, Korespondencja abp. Józefa Teodorowicza z abp. Adamem Stefanem Sapieha, dokument 74.

${ }_{12}$ Zob. w niniejszej publikacji: tenże, Korespondencja abp. Józefa Teodorowicza z bp. Henrykiem Przeździeckim, dokument 4.

${ }^{13}$ Marienbad - miasto w Czechach, od XIX w. było popularnym kurortem odwiedzanym przez europejskie sfery arystokratyczne i kościelne.

a Tekst pisany czarnym atramentem na jednej stronicy papieru formatu A4. 
Przypomina sobie Pan zapewne, jak raz pisałem Panu, że małżeństwo Państwa mimo wszelkich ludzkich nieprawdopodobieństw i wątpliwości, i zastrzeżeń wiąże się jednak widocznie planem i zamierzeniem Bożym ${ }^{14}$. Wtedy widziałem [... $]^{\mathrm{b}}$ dopiero, który wypełnić musiała Wasza zobopólna ${ }^{\mathrm{c}}$ wola i praca wobec tylu trudności. Kwestia była w tym, czy dociągniecie siebie do myśli i planów Bożych, czy prężąc się struna duszy po tej czy tamtej stronie nie zerwie się i nie pęknie. To były obawy moje nie o plan Boży, o którym nie wątpiłem, ale o egzekutorów tego planu - to jest Was.

Zrozumie Pan dlatego, jak mnie uradować musiał i uradował list Pański donoszący o tak bliskim już, a tak pewnym terminie Waszego ślubu.

Nie wątpię, że zjednoczenie w tej wyższej myśli Bożej wspartej o poczucie wielkiej zobopólnej odpowiedzialności, a wsparcie mocą tego, który nam misję wyznaczył i do niej powołał, zbudujecie rodzinę będącą jedną z ostoi i twierdz duchowego i narodowego życia, jak i narodowej myśli. Szczęść Boże! W dniu Waszego ślubu odprawię w intencji Waszej Mszę św.

Co do mieszkania, to zostało ono wskutek nowych awantur Reszytyły ${ }^{15}$ przez policję opieczętowane.

Proszę darować niedbałą formę [listu], ale piszę ten list na jednym z postojów marienbadzkich. Zabawię tu jeszcze $10 \mathrm{dni}$. Na inne kwestie nie odpowiadam już teraz, pozostawiam je do ustnego omówienia.

Obojgu Państwa przesyłam z błogosławieństwem najoddańsze wyrazy i życzenia

† Teodorowicz

\section{Dokument 7}

Oryg.: APANP, sygn. P III - 116, teczka 86, List abp. Józefa Teodorowicza do prof. Stefana Dąbrowskiego, Lwów 14 IV 1931 r.

\section{$\dagger$}

Kochany ${ }^{\mathrm{a}}$ Panie Pośle!

Tylko cierpliwości! Rzecz się robi tylko niech Pan po mojej niedzielnej bombie nie mówi, iż my milczymy. Biedni nowi gospodarze uroczystości, tj. Ojcowie, którzy mnie zaprosili! Siedzieli jak struci. Ale doprawdy widzę, że społeczeństwo już dojrzewa dla

${ }^{14}$ Prof. Dąbrowski był dwukrotnie żonaty. Pierwsza żona Malwina z d. Roszkowska - córka Gustawa i Katarzyny, zamieszkałych we Lwowie, poślubiona została w 1908 r. tamże. Miał z nią czworo dzieci: Stefana (1910-1955), Helenę (1912-1925), Jana (1914-1979) i Zofię (1922-1990). Po śmierci pierwszej żony, prof. Dąbrowski ożenił się w roku 1930 z Zofią z d. Żółtowską (1887-1975); owocem tegoż związku była córka Jadwiga (ur. 1931 r.). J. Malinowski, Stefan Dąbrowski (1877-1947), s. 45; M. Smogorzewska, Postowie i senatorowie Rzeczypospolitej Polskiej 1919-1939. Stownik biograficzny, t. 1, Warszawa 1998, s. 360; źródło: Zofia Dąbrowska Żółtowska (1877-1975) Genealogy - Geni. Com., https://www.geni.com/.../Zofia-Dąbrowska/600000003026053625. Dostęp 21 VIII 2018 r.

b Wyraz nieczytelny.

c Zgodnie z oryginałem.

15 Prawdopodobnie ukraiński duchowny greckokatolicki walczący o przejęcie klasztoru oo. Bazylianów przy ul. Miodowej w Warszawie, w którym mieszkanie miał m.in. abp. Józef Teodorowicz.

a Tekst pisany czarnym atramentem na jednej stronicy papieru formatu A4. 
przyjęcia pewnych prawd. Dostaję list [y] z podziękowaniami, po miastach i wsiach, gdzie przez radio kazania słuchano formalnie zawrzało ${ }^{16}$. Kiedy wracałem z Krakowa z Biskupem Lisowskim ${ }^{17}$, jego siostrzenica z mężem witała go na dworcu i nie wiedząc, kto głosił naukę mówiła, iż w całym Przemyślu tylko o tym się mówi, iż ktoś nareszcie powiedział prawdę. Mimo woli i mimo chęci muszę o sobie mówić, ale te wyrazy nie odnoszę wcale do siebie tylko do prawd głoszonych bardzo prostych, ale i bardzo zasadniczych, których ludzie są więcej spragnieni i bardziej do nich dojrzali, niż to się nam samym zdaje.

Tymczasem bardzo serdeczne i oddane wyrazy łączę dla Pana Profesora i Pani ${ }^{18}$

† Teodorowicz

Lwów, d[nia] 14/IV [1]931

\section{Dokument 8}

Kopia: AFKDOPW, teczka 128: Spuścizna abp. Józefa Teodorowicza, sygn. 1260/420 (12) [7], List abp. Józefa Teodorowicza do prof. Stefana Dąbrowskiego, Lwów 9 VII 1932 r.

Kochany ${ }^{\text {Panie Pośle! }}$

Zwracam się do pana w sprawie naszego wspólnego znajomego pana Lewaka ${ }^{19}$. Mógłbym wprawdzie bezpośrednio pisać do pana Jeleńskiego ${ }^{20}$, ale nie chcę tej sprawy od razu stawiać już na formalnym gruncie; dlatego przedstawiam ją Panu Profesorowi do wybadania delikatnego sytuacji. Sprawa ma się tak.

Jak Panu wiadomo, pan Lewak jest zatrudniony w Ossolineum i ma tu wybitne stanowisko. Umiał sobie wyrobić zaufanie i poważanie tak, że zarówno Lubomirski ${ }^{21}$, jak i całe kuratorium są pełni uznania dla niego i z pewnością nie chcieliby się za żadną cenę pozbyć. Jest on przy tym znakomicie obznajomiony z kwestiami szkolnymi i ma duże znajomości w Ministerstwie Oświaty w Warszawie.

Znana Panu jego sytuacja rodzinna dziś się kształtuje w ten sposób, że nie byłoby dla niego wskazane opuszczenie Lwowa i przeniesienie się gdzie indziej; jedynym miejscem dla niego odpowiednim byłaby Księgarnia św. Wojciecha ${ }^{22}$.

16 J. Teodorowicz, Państwo chrześcijańskie a państwo pogańskie. Kazanie, Lwów 1931.

17 Zob. w niniejszej publikacji: J. Wołczański, Korespondencja abp. Józefa Teodorowicza z abp. Adamem Stefanem Sapiehą, dokument 77.

${ }_{18}$ Aluzja do żony prof. Dąbrowskiego - Zofii.

a Tekst pisany maszynowo na 1,5 stronicy papieru formatu A4. Brak autografu autora.

${ }^{19}$ Lewak Antoni (1889-1940?), prawnik, pracownik lwowskich i warszawskich kancelarii prawniczych oraz redakcji czasopism, 1928-1939 dyrektor wydawnictwa Zakładu Narodowego im. Ossolińskich we Lwowie, aresztowany przez Sowietów w 1939 r. we Lwowie, został zamordowany prawdopodobnie w $1940 \mathrm{r}$. Źródło: Rok Jubileuszowy - 128. rocznica urodzin Antoniego Lewaka ...https://ossolineum.pl/index.../ rok-jubileuszowy-128-rocznica-urodzin-antoniego-lewaka. Dostęp 21 VIII 2017 r.

${ }^{20}$ Jeleński Szczepan (1881-1949), inżynier i pisarz, w latach międzywojennych pełnił funkcję dyrektora Księgarni św. Wojciecha w Poznaniu. Jeleński Szczepan, w: WSB, red. A. Gąsiorowski, J. Topolski, Warszawa-Poznań 1981, s. 296.

${ }^{21}$ Zob. w niniejszej publikacji: J. Wołczański, Listy abp. Józefa Teodorowicza do abp. Józefa Bilczewskiego, dokument 68.

${ }^{22}$ Aluzja do drukarni i wydawnictwa funkcjonującego w Poznaniu. 
Otóż prosiłbym Pana Profesora, aby był łaskaw - prosząc o ścisłą dyskrecję - wybadać pod tym względem opinię p[ana] Jeleńskiego. Odpowiedź proszę przesłać wprost p[anu] Lewakowi, albowiem ja obecnie wyjeżdżam ze Lwowa. W niedzielę jadę na cały tydzień do Wiednia, gdzie mam święcić Mechitarzystów ${ }^{23}$, a stamtąd jadę do Marienbadu, później zaś do Salzburga ${ }^{24}$ z wykładami dla Niemców.

Dawno nie miałem żadnej wiadomości od Pana Profesora. Łączę dla obojga Państwa bardzo serdeczne, prawdziwie oddane wyrazy czci.

Lwów, dnia 9 lipca 1932

J[aśnie] W[ielmożny] Pan Profesor Stefan Dąbrowski

Poznań - [ul.] Mickiewicza 30

\section{Dokument 9}

Kopia: AFKDOPW, teczka 128: Spuścizna abp. Józefa Teodorowicza, sygn. 1428/420 (12) [7], List abp. Józefa Teodorowicza do prof. Stefana Dąbrowskiego, Lwów 14 V 1933 r.

Przezacny ${ }^{\mathrm{a}}$, Kochany Panie Pośle!

Dziękuję najuprzejmiej za list Pański i cieszę się z niezmordowanego apostolstwa Pańskiego, które jak widzę coraz szersze zakreśla kręgi. Dla mnie, niestety, trochę trudno wiązać się terminem czerwcowym, zwłaszcza, że się czuję dziś przemęczonym fizycznie i będę musiał gdzieś wyjechać. Szkoda, bo mię ta praca bardzo by nęciła.

Rozmawiałem natomiast z O. Ficem ${ }^{25}$ (tak się nazywa ten dominikanin, o którym Pan pisze) i on podjąłby się bardzo chętnie takich rekolekcji; ma tylko jedną przeszkodę do usunięcia, to jest jego egzamin na profesora w Krakowie. Obiecał mi, że się porozumie z księdzem Archutowskim ${ }^{26}$ i jak mu się zdaje, przeszkoda ta może być usunięta. Może się więc Pan z nim porozumieć, adresując [list] do Lwowa do klasztoru OO. Dominikanów.

Dużo rzeczy byłoby jeszcze do omówienia, ale list się do tego nie nadaje. Łączę dla czcigodnych Państwa wyrazy bardzo oddane głębokiej czci.

Lwów, dnia 14 maja 1933

${ }^{23}$ Zob. w niniejszej publikacji: J. Wołczański, Korespondencja abp. Józefa Teodorowicza zabp. Adamem Stefanem Sapieha, dokument 34.

${ }^{24}$ Salzburg - alpejskie miasto w dzisiejszej północno-zachodniej Austrii.

a Tekst pisany maszynowo na 1,5 stronicy papieru formatu A4. Brak autografu autora.

${ }^{25}$ Fic Urban Atanazy (1901-1943), święcenia kapłańskie w 1925 r. w Zakonie oo. Dominikanów, dr teologii, w 1933 r. habilitacja z dziedziny biblistyki, 1930-1933 wykładowca w studium zakonnym we Lwowie, 1936-1939 docent Wydziału Teologicznego UJK, 1939-1943 przebywał w Krakowie, w 1943 r. zginął we Lwowie. J. Wołczański, Wydział Teologiczny Uniwersytetu Jana Kazimierza we Lwowie 1918-1939, Kraków 2002, s. 205.

${ }^{26}$ Archutowski Józef (1879-1944), święcenia kapłańskie w 1904 r. dla archidiec. warszawskiej, dr teologii, 1918-1920 prof. biblistyki KUL, 1920-1930 analogicznie na Wydziale Teologicznym UJ, 1939-1940 więzień obozu Sachsenhausen, 1943-1944 proboszcz par. pw. Nawiedzenia NMP w Warszawie, zginął podczas Powstania Warszawskiego; autor publikacji z dziedziny języków orientalnych i Starego Testamentu. F. Gryglewicz, Archutowski Józef, w: EK, t. 1, red. zbior., Lublin 1985, kol. 889-890. 
Pan Poseł Stefan Dąbrowski

Poznań - [ul.] Mickiewicza 30

\section{Dokument 10}

Kopia: AFKDOPW, teczka 136: Spuścizna abp. Józefa Teodorowicza, sygn. 1436/185 [4], List abp. Józefa Teodorowicza do prof. Stefana Dąbrowskiego, Lwów 8 XI 1933 r.

Przezacny ${ }^{\mathrm{a}}$, Kochany Panie Profesorze!

Właśnie miałem wczoraj telefon od pana Lewaka, że Pan Profesor myśli o krytyce mej książki i że czeka tylko na to, ażeby się ze mną porozumieć, co do przewodnich pryncypiów.

Otóż bardzo dziękuję Panu Profesorowi za dawno już okazaną mi gotowość krytyki; przytaczam tu główny szkic, na którego oddaniu mi zależy z pewnych poważnych względów, których tu teraz w liście poruszać nie mogę, ale opowiem je przy pierwszej sposobności Panu Profesorowi.

Idzie mianowicie o to głównie, aby wykazać, na czym mi zależało i co zarzucałem O. Siwkowi. Próbkę taką posyłam ${ }^{\mathrm{b}}$ Panu Profesorowi, którą proszę albo dosłownie przytoczyć bezimiennie oczywiście lub też odpowiednio ze swojej strony rzecz całą ubrać.

Jeszcze raz gorąco i serdecznie dziękuję za ten nowy przyjacielski uczynek Pana Profesora, a przy tym donoszę, że zdrowie moje radykalnie się polepszyło i po ludzku mówiąc idę ku zupełnemu wyzdrowieniu. Powodem mojej choroby nie było co innego, jak tylko przemęczenie umysłowe, które jeszcze zostało przypieczętowane kilkakrotnym radiowaniem ${ }^{27} \mathrm{w}$ celu wywabienia reumatyzmu. Tymczasem radiowe zabiegi miast wypędzić mój reumatyzm uderzyły na serce i je osłabiły; stąd powstało osłabienie mięśnia sercowego u mnie.

Jakżebym bardzo chciał z Panem Profesorem kiedyś się zobaczyć i o tylu, tylu rzeczach pomówić!

Tymczasem łączę dla Pana Profesora najoddańsze wyrazy szacunku i przyjaźni wraz z ukłonami dla Pani.

Lwów, dnia 8 listopada 1933

\section{Dokument 11}

Kopia: AFKDOPW, teczka 128: Spuścizna abp. Józefa Teodorowicza, sygn. 1408/185 [4], List abp. Józefa Teodorowicza do prof. Stefana Dąbrowskiego, Lwów 2 I 1934 r.

Kochanya Panie Pośle!

a Tekst pisany maszynowo na 1,5 stronicy papieru formatu A4. Brak autografu autora.

b Brak owego dokumentu.

${ }^{27}$ Zapewne autor pisze o naświetlaniu rentgenowskim chorych miejsc celem usunięcia dolegliwości.

a Tekst pisany maszynowo na 1,5 stronicy papieru formatu A4. Brak autografu autora. 
Bardzo się stęskniłem za wiadomościami o Panu Pośle, więc pojmie Pan, jak pożądany był mi list, który właśnie otrzymuję.

Dzięki Bogu, że złe przechodzi i że się Państwo tak kochacie, iż cierpienie Was jeszcze bardziej zbliża przez wzajemną ofiarę cierpliwości i oddania. Niesłychanie to szczęśliwie, że Pan Poseł może jeden jedyny utrzymuje stały kontakt $\mathrm{z}$ katolickimi sferami Francji. Co do pana Edwarda ${ }^{28}$, to nie ma takiej siły, która by była zdolna go z Huty ${ }^{29}$ wyciągnąć; na to już nie ma zupełnie rady.

Co do mnie, to $\mathrm{w}$ tym roku zachorowałem z przemęczenia na osłabienie mięśnia sercowego i mam się wprawdzie już dobrze, ale muszę bardzo uważać na siebie. Przy pierwszym zaraz konsylium powiedział mi lekarz, że tu nie pomogą żadne lekarstwa, a jedynie tylko wypoczynek. Zdaje mi się, że wyjadę teraz na parę tygodni do Krynicy. Jeszcze raz Panu bardzo serdecznie za list dziękuję i dla obojga Państwa łączę wraz z życzeniami bardzo oddane wyrazy czci.

Lwów, dnia 2 stycznia 1934

Pan Poseł Stefan Dąbrowski

\section{Dokument 12}

Oryg.: APANP, sygn. P III - 116, teczka 86, List abp. Józefa Teodorowicza do prof. Stefana Dąbrowskiego, Lwów 6 III 1934 r. Kopia: AFKDOPW, teczka 128: Spuścizna abp. Józefa Teodorowicza, sygn. $1605 / 185$ [4].

Kochany ${ }^{\mathrm{a}}$, Przezacny Panie Profesorze!

Ogromnie się zmartwiłem wiadomością o chorobie Pana Profesora. Odprawiłem mszę św. w intencji uzdrowienia Pana Profesora i mam wielką ufność w Bogu, że nam Pana Profesora zdrowym powróci. Choroba ta ciężka tylko tym bardziej zjednoczy przez krzyż obojga Państwa, a duszę Pana Profesora oczyści i do wyżyn myśli i woli Bożej w pełni dostroi. O to się modlę i Najświętszej Matce Pana Profesora szczególniej polecam.

Zresztą Pan Profesor sam musi się uważać za rodzaj zastawu nam danego na te ciężkie chwile i czasy. Nie wolno więc takiego zastawu, jaki mamy w osobie Pana Profesora

${ }^{28}$ Dubanowicz Edward (1881-1943), dr prawa i filozofii, 1913-1914 poseł do Sejmu Galicyjskiego, w 1921 r. inicjator utworzenia Narodowo-Chrześcijańskiego Stronnictwa Ludowego, członek redakcji „Rzeczpospolitej” i „Warszawianki”, członek prezydium Tymczasowej Komisji Rządzącej b. Galicji we Lwowie, podczas wojny z bolszewikami 1920 r. członek Rady Obrony Państwa, 1917-1934 kierownik Katedry Prawa Państwowego UJK we Lwowie, 1919-1923 prof. KUL, 1919-1927 poseł na Sejm RP, właściciel majątku w Hucie Szklanej k. Brodów, 1940-1941 zesłany przez władze sowieckie do Kazachstanu, 1942-1943 przebywał w Londynie gdzie zmarł; autor publikacji z dziedziny historii państwa i prawa. M. Smogorzewska, Postowie i senatorowie Rzeczypospolitej Polskiej 1919-1939. Stownik biograficzny, t. 1, oprac. M. Smogorzewska, Warszawa 1998, s. 421-423.

${ }^{29}$ Właściwie: Huta Szklana - wieś w pow. Brody, woj. Tarnopol; własność Marii Magdaleny i Edwarda Dubanowiczów.

a Tekst pisany czarnym atramentem na jednej stronicy papieru formatu A4. 
kurczyć albo go sprzeniewierzać; w takim bowiem razie czeka Pana Profesora proces, który powinien z góry odstraszyć Pana od wszelkich niepożądanych eksperymentów ze swoim zdrowiem.

Co do mnie, to chorowałem dłuższy czas także ciężko. Jestem jednak dzisiaj już na wyzdrowieniu. Jeżeli przy pomocy Bożej ja w mych latach tę sztukę potrafię, to niechże Pan Profesor nie daje się niczym zawstydzić w swoich latach i przy swoim silnym organizmie.

Pewnie Pana Profesora ucieszył list pasterski, który - jak widzę - ma swoje silne i potężne echo. Jest to przede wszystkim zasługa ks. Prymasa ${ }^{30}$.

Łączę tymczasem dla obojga Państwa najserdeczniejsze pozdrowienia i najoddańsze wyrazy, prosząc choćby na kartce o parę słów wiadomości, jak się Pan Profesor miewa.

† Teodorowicz

Lwów, dnia 6 marca 1934

\section{Dokument 13}

Kopia: AFKDOPW, teczka 128: Spuścizna abp. Józefa Teodorowicza, sygn. 1519/185 [4], List abp. Józefa Teodorowicza do prof. Stefana Dąbrowskiego, Lwów 13 XII 1934 r.

Kochany ${ }^{\mathrm{a}}$ Panie Profesorze!

Bardzo się ucieszyłem listem Pańskim, bo już się tak stęskniłem za jakąś wiadomością o Panu.

Dzięki Bogu, że zdrowie Pana po tych strasznych przejściach, jakkolwiek powoli, wraca jednak do normalnego stanu. Tak jest Pan nam bardzo potrzebny, więc dziękuję Bogu, że nam Pana zachował. Moje zdrowie również wraca do dobrego stanu. Przyznaję się Panu, że się nie spodziewałem po zeszłorocznych tarapatach polepszenia i to polepszenia takiego; jeszcze się oszczędzam, wyjeżdżam jak najmniej, ale na ogół czuję się dobrze.

Może to i dobrze dla zdrowia Pana, że nie jest Pan w samym wirze życia w Poznaniu, ale skazany zostaje Pan Profesor na przymusowe oddalenie, a jednak nie tak wielkie od Poznania.

Jakoś tylko Pani zaniedbała się w pisaniu, bo nie czytam jej artykułów; pewnie troska dokoła Pana była przyczyną tego zaabsorbowania.

Biedny Jędrzejewskib zbankrutował na swoich wydawnictwach. Byłoby bardzo dobrze, gdyby przez pośrednictwo Prymasa dać mu jakieś miejsce, może najlepiej redaktora dziennika katolickiego, który ma powstać. To człowiek wielkiej wartości, a jak mi się zdaje, jest w ciężkich warunkach finansowych.

${ }^{30}$ List pasterski Episkopatu Polski o ducha chrześcijańskiego w Polsce, Warszawa 20 II 1934 r.

a Tekst pisany maszynowo na 2,5 stronicy papieru formatu A4. Brak autografu autora.

b Osoba niezidentyfikowana. 
Świetną Pan dał charakterystykę osoby i charakteru naukowego O. S[iwka ${ }^{31}$. Ten człowiek swym racjonalizmem wiele bardzo szkody przynosi młodemu pokoleniu, które w Rzymie naucza. Umysł to mniej niż przeciętny, który swoje sukcesy zawdzięcza nie talentowi, ale zręczności ogromnej i umiejętności reklamy; nie umie się wyzbyć trutki racjonalizmu, jaki weń wstrzyknął jego profesor paryski, znany racjonalista, Janet ${ }^{32}$.

Kiedy pan Profesor się też pokaże u nas? My tu śpimy na dobre, albowiem między młodym pokoleniem niestety niekierowanym a starym, nie ma bezpośredniego czynnika, który by nadawał ton i kierownictwo. Ja się już od wszystkiego odsunąłem i tkwię tylko wyłącznie w literaturze, a ponieważ mi Pan delikatnie wymyśla za „Życie Chrystusa Pana" ${ }^{33}$ więc powiem, że mam na ukończeniu już tom następny. Będzie on jednak poświęcony wstępnym pojęciom głownie St[arego] Testamentu i prądom w żydostwie współczesnym Chrystusowi Panu. Zauważyłem bowiem, że jest ogromne zamieszanie pojęć i brak elementarnej znajomości St[arego] Testamentu; dlatego taki pamflet na St[ary] Testament jak profesora Zielińskiego ${ }^{34}$ mógł u nas odnieść taki sukces.

Cieszę się, że Prymas idzie w górę przez swoje zagraniczne wpływy, a tym samym i u nas, bo jak zawsze to, co otrzyma zagraniczny patent dopiero szanowane jest przez nas; byle tylko szanował swoje zdrowie tak dla nas cenne i potrzebne.

Stroński miał tu być i był nawet zapowiedziany jego odczyt we Lwowie i nie wiem, dlaczego nie przyjechał. Dubanowicze byli u mnie niedawno; zajęci [są] wyłącznie wychowaniem dzieci i gospodarstwem. Z emeryturą pana Edwarda zerwany został ostatni łącznik jego ze Lwowem i zdaje mi się też z wszelką pracą szerszą.

Posyłam Panu Profesorowi moją mowę, jaką miałem 8-go grudnia na obchodzie pamiątki założenia sodalicji. Może Pana będzie interesować ostatni ustęp mojej mowy, w którym jest atak chociaż bezimienny na tych czterech profesorów uniwersytetu biorących udział w kongresie bezbożników; jeden z nich jest Pańskim kolegą na uniwersytecie poznańskim.

Jeszcze raz serdecznie Panu dziękuję za list, za łaskawe względy dla mnie i pamięć, i łączę dla Państwa wyrazy oddane prawdziwej przyjaźni i głębokiego szacunku.

Lwów, dnia 13 grudnia 1934

Jaśnie] Wielmożny Pan Profesor

Stefan Dąbrowski - Puszczykowo Stare - Pozn[ań].

${ }^{31}$ Zob. w niniejszej publikacji: J. Wołczański, Korespondencja abp. Józefa Teodorowicza z abp. Adamem Stefanem Sapieha, dokument 101.

${ }_{32}$ Janet Pierre Marie Félix (1859-1947), francuski lekarz, psycholog i neurolog, od 1902 r. prof. psychologii Cellège de France w Paryżu.

${ }^{33}$ J. Teodorowicz, Jezus Chrystus, t. 2: Od Betlejem do Nazaretu, Poznań 1932.

${ }^{34}$ Zob. w niniejszej publikacji: J. Wołczański, Korespondencja abp. Józefa Teodorowicza z abp. Adamem Stefanem Sapieha, dokument 110. 


\section{Dokument 14}

Kopia: AFKDOPW, teczka 128: Spuścizna abp. Józefa Teodorowicza, sygn. 116/19 [6], List abp. Józefa Teodorowicza do prof. Stefana Dąbrowskiego, Lwów 9 I 1935 r.

Kochany ${ }^{\mathrm{a}}$ Przezacny Panie Pośle!

Prawdziwie miłą niespodzianką był dla mnie list Pański i ucieszyłem się tym, że Pan choć zbyt późno niestety, ale zaczyna myśleć naprawdę o swym zdrowiu, tak dawniej przez Pana nieszanowanym, prawie - powiedziałbym - marnowanym.

Jak już to Panu pisałem, mam się obecnie lepiej, nawet względnie dobrze. Nie umiem powiedzieć jakbym się cieszył, gdyby Pan do Lwowa zawitał, a zrobił mi Pan w liście nadzieję na to, którą biorę już za obietnicę.

Cieszę się z tego, że Pan nawróci się powoli do pióra. Czy czytał Pan p[ani] Pannenkowej ${ }^{35}$ „Więzy"? ${ }^{36}$ Jest to może jedyna rzecz, która popularnie mówi w formie powieści o obronie Lwowa. Czy by Pan w wolnej chwili nie mógł kilku słów krytyki o tej książce napisać podpisując siebie? To by ją bardzo ucieszyło, a podniosłoby i sprawę samą, która niestety idzie w zapomnienie.

Tymczasem tyle; resztę zostawiam sobie na widzenie się i rozmowę z Panem. Łączę tymczasem życzenia najlepsze noworoczne, a więc przede wszystkim zdrowia dla Państwa, zawsze oddany Panu.

Lwów, 9 stycznia 1935

\section{Dokument 15}

Kopia: AFKDOPW, teczka 128: Spuścizna abp. Józefa Teodorowicza, sygn. 886/110 [5], List abp. Józefa Teodorowicza do prof. Stefana Dąbrowskiego, Lwów 15 II 1936 r.

Kochany ${ }^{\mathrm{a}}$ Panie Profesorze!

Tak dawno nie miałem wiadomości od Pana, że się szczególnie ucieszyłem listem Pańskim, zaś praca Pańska jest mi dowodem, że Pan wcale nie myśli spoczywać na laurach.

Książkę Pana ${ }^{37}$ czyta się jednym tchem; łączy ona w sobie bardzo praktyczne wskazania i przypomnienia z teorią naukową i stanowiskiem wszędzie podkreślanym Kościoła; wyświetla ona znakomicie ten problem, który tyle zamętu wytworzył i coraz to w głowach wytwarza. Tylko Pani jakoś nic nie pisze.

a Tekst pisany maszynowo na 1,5 stronicy papieru formatu A4. Brak autografu autora.

35 Pannenkowa Irena Aniela ((1879-1969), publicystka, dziennikarka, 1910-1914 nauczycielka w prywatnych szkołach średnich we Lwowie, 1914-1917 współpracowała z Naczelnym Komitetem Narodowym, w 1915 r. mieszkała w Krakowie, 1915-1919 we Lwowie, od 1920 r. w Warszawie, współpracowniczka „Kuriera Lwowskiego”, „Rzeczpospolitej”, w czasie wojny ukraińsko-polskiej 1918-1919 członkini Komitetu Obrony Narodowej we Lwowie, w 1919 r. założycielka Narodowej Organizacji Kobiet tamże. E. Romer, Pamiętnik paryski 1918-1919, t. 1, red. S. Sierpowski, Wrocław 2010, s. 294-295.

36 A.I. Pannenkowa, Więzy, Warszawa 1935.

a Tekst pisany maszynowo na 1,5 stronicy papieru formatu A4. Brak autografu autora.

37 S. Dąbrowski, Eugenika ze stanowiska katolickiego, Poznań 1936. 
Co do mnie, to mi zdrowie na tyle służy, że mogę wydawać jeszcze książki. Wysłałem już do druku w niemieckim języku książkę o Konnersreuth ${ }^{38}$, a w Poznaniu drukuje się książka moja o Starym Testamencie w związku z chrystologią ${ }^{39}$.

Z serdeczną podzięką łączę dla Przezacnych Państwa moje prawdziwie oddane wyrazy głębokiej czci.

Lwów, 15 lutego 1936

Pan Stefan Dąbrowski

\section{Dokument 16}

Oryg.: APANP, sygn. P III - 116, teczka 86, List abp. Józefa Teodorowicza do prof. Stefana Dąbrowskiego, Lwów 28 XII 1936 r. Kopia: AFKDOPW, teczka 128: Spuścizna abp. Józefa Teodorowicza, sygn. $794 / 110[5]$.

\section{Kochany ${ }^{\mathrm{a}}$, Przezacny Panie!}

Jakże to Pan się umiał ukryć się ze swoją zawodową wiedzą, o której tyle szczegółów się dowiedziałem od Profesora Kmietowicza ${ }^{40}$. Podobno imię Pana znane jest w podręcznikach niemieckich na podstawie Pańskich prac. Wykorzystuję to więc zaraz dla siebie.

Sprawa jest następująca. Niejaki Dr Deutsch ${ }^{41}$ katolik niemiecki znany z tego, że nienawidzi Konnersreuth i ustawicznie nań uderza, uderzył teraz na mnie w liście otwartym, względnie na moją książkę. List ten napisany w tonie tak impertynenckim i grubiańskim, iż arcybiskup krakowski, którego się w tej sprawie radziłem powiedział mi, że nie mogę absolutnie na podobny list odpowiadać. Wobec tego podjął się odpowiedzi znany Panu mój kanonik ks. Bogdanowicz ${ }^{42}$. Idzie jednak o to, ażeby w kwestiach lekarskich mógł się on na kogoś powołać, który jego wywody zaaprobuje. Idzie tu głownie o wywód dotyczący przemiany materii skutkiem głodu. W tej dziedzinie jest Dr Deutsch zupełnym dyletantem, który jest operatorem i lekarzem kobiecym. Opiera się on z umysłu na

${ }^{38}$ J. Teodorowicz, Konnersreuth im Lichte der Mystik und Psychologie, Salzburg-Leipzig 1936.

39 Tenże, Jezus Chrystus, t. 1: Od Jahwe do Mesjasza, Poznań 1936.

a Tekst pisany maszynowo z wyjątkiem autografu autora na dwóch stronicach papieru formatu A4. W prawym górnym rogu karty tytułowej nota czarnym atramentem zapewne ręką adresata: „30/XII [19]36”.

${ }^{40}$ Kmietowicz Franciszek Ksawery (1892-1940), dr medycyny, 1921-1934 starszy asystent na Wydziale Lekarskim UJK we Lwowie, w 1934 r. habilitacja tamże, 1934-1940 docent tamże, autor publikacji z dziedziny balneologii oraz klimatologii. S. Brzozowski, Kmietowicz Franciszek Ksawery, w: PSB, t. 13, red. zbior., Kraków 1967, s. 83.

${ }^{41}$ Deutsch Joseph - dr medycyny, dyrektor Dreifaltigkeitshospitals w Lippstadt (Westfalia - Niemcy), jeden z głównych przeciwników Teresy Neumann, autor publikacji podważających autentyczność jej stygmatów i objawień, m.in.: Konnersreuth in ärztliche Beleuchtung (1932), Ärztliche Kritik an Konnersreuth! Wunder oder Hysterie? (Lippstadt 1938).

${ }^{42}$ Zob. w niniejszej publikacji: J. Wołczański, Listy abp. Józefa Teodorowicza do abp. Józefa Bilczewskiego, dokument 141. 
niejakim doktorze Heermannie ${ }^{43}$, który jest również dyletantem i z zawodu jest lekarzem uszu i tylko przygodnie brał lekcje u doktora Hohna ${ }^{44}$ umyślnie w tym celu, by na Konnersreuth uderzyć.

Pan będzie łaskaw, o co bardzo proszę, przejrzeć odpowiedź w tej dziedzinie doktorowi Deutschowi i o ile by tekst tej odpowiedzi był bez zarzutu pod względem naukowym, prosiłbym Pana o kilka słów, które by można w odpowiedzi przytoczyć, powołując się na Pana. Mniej więcej wyobrażam sobie pismo Pana w ten sposób, iż Pan stwierdza, że przeczytał cały rozdział odpowiedzi ks. Bogdanowicza o głodzie i uważa Pan, że ze stanowiska naukowego cała ta rozprawa ks. Bogdanowicza jest bez zarzutu. O ile by Pan uważał za stosowne jeszcze coś od siebie dodać, to oczywiście będzie to tylko lepiej.

Z moją prośbą łączę podziękę za artykuł przysłany przez Panią ${ }^{45}$, który jest bardzo jasny i dosadny, i mimo zastrzeżeń redakcji zmusił ją jednak do zerwania z dwuznacznymi stawieniami kwestii; musieli jasno powiedzieć, co myślą i czego chcą.

Korzystam z tej sposobności, ażeby załączyć dla Czcigodnych i Kochanych Państwa moje najserdeczniejsze życzenia świąteczne i noworoczne wraz z oddanymi wyrazami mojej czci i szacunku

† Teodorowicz ${ }^{\mathrm{b}}$

Lwów, dnia 28 grudnia 1936

\section{Dokument 17}

Oryg.: AFKDOPW, teczka 139: Spuścizna abp. Józefa Teodorowicza, sygn. 1300/365 [5], List prof. Stefana Dąbrowskiego do abp. Józefa Teodorowicza, Puszczykowo Stare 4 I 1937 r.

Puszczykowo Stare k/Poznania, 4 stycznia 1937

Najczcigodniejszy ${ }^{\mathrm{a}}$ Ks. Arcybiskupie!

Otrzymałem pisma Jego Ekscelencji i Ks. Bogdanowicza w sprawie krytyki, którą napisał Dr Deutsch o książce Ks. Arcybiskupa. Już o tej krytyce, rzekomo fachowej, mówił mi jesienią b.r. Ks. Kardynał Prymas ${ }^{46}$ zaniepokojony, czy ostoi się książka Ks. Arcybiskupa wobec lekarskiej krytyki w tych miejscach, w których mowa jest o procesach czysto fizjologicznych.

Przede wszystkim dziękuję za zaufanie, które zechciał mi Ks. Arcybiskup okazać w rzeczach tym razem... niedotyczących polityki. Nie wiem, czy Najczcigodniejszego

${ }^{43}$ Heermann Hans (1900-1996), niemiecki lekarz, dr medycyny, specjalista w zakresie otolaryngologii, 1933-1967 naczelny lekarz jednego z oddziałów Szpitala Alfrieda Kruppa w Essen, w 1960 r. otrzymał tytuł profesora za swe osiągnięcia; autor m.in. pracy: Um Konnersreuth (1932). Źródło: Hans Heermann - Wikipedia, https://de.wikipedia.org/wiki/Hans_Heermann. Dostęp: 11 XI 2018 r.

${ }^{44}$ Osoba niezidentyfikowana.

${ }^{45}$ Aluzja do niezidentyfikowanego artykułu drugiej żony prof. Dąbrowskiego - Zofii.

b Autograf czarnym atramentem ręką abp. J. Teodorowicza.

a Tekst pisany czarnym atramentem na 2,5 stronicach papieru formatu A4.

${ }^{46}$ Prymas Polski kard. August Hlond. 
i Dostojnego mego Przyjaciela i Kierownika nie zawiodę? Ale spróbuję zmierzyć się z kol[egą] Deutschem. Nawet uczynię to chętnie. Tak się składa właśnie, że od początku roku szkolnego redaguję szereg prac moich i moich uczniów do Biuletynu Międzynarodowego Polsk[iej] Akad[emii] Umiej[ętności]. Pięć z nich już referowałem 20/XI r[oku] $\mathrm{u}$ [biegłego] na posiedzeniu Wydz[iału] lek[arskiego] Akad[emii] Umiej[ętności], bo po paru latach zebrało się tyle wykończonych studiów.

Z kolei zabieram się do pracy, którą razem z moim przyjacielem śp. S[tanisławem] Kozłowskim ${ }^{47}$ wykończyłem jeszcze w r. 1914 we Lwowie, w pracowni śp. prof. St[anisława] Bądzyńskiego ${ }^{48}$. Piszę ją po francusku, a dotyczy ona przemiany materii w czasie dwutygodniowego bezwzględnego głodu ${ }^{49}$, którą na sobie przeprowadzał jeden z moich uczniów, obecnie docent Un[iwersytetu] Pozn[ańskiego]. Może zatem nie gorzej od p[ana] kol[egi] Deutscha znam przebieg somatycznych procesów w czasie głodówki i postaram się przejrzeć jego w tym kierunku dorobek.

W każdym razie szkoła prof. Bądzyńskiego ma na głód wyrobiony pogląd. Np. śmierć z głodu nie jest bynajmniej spowodowana tym, że w ustroju już nie ma zapasów odżywczych, mimo skrajnego wychudzenia; śmierć ta jest spowodowana zakwaszeniem ustroju, gdyż ustrój pozostawiony sam sobie bez dowozu zasad [z] zewnątrz wytwarza szereg kwasów nielotnych, które demineralizują ustrój tak, iż śmierć z głodu jest śmiercią z samozatrucia kwaśnymi odpadkami przemiany materii, jest śmiercią z powodu autointoksykacji kwasowej. Czy poglądy fizjologiczne z tej dziedziny mogą w czymkolwiek wyjaśnić przypadek z Konnersreuth? - tego nie umiem powiedzieć. A priori $^{50}$ wydaje mi się, że zjawiska cudowne nie mogą znaleźć wytłumaczenia na drodze naukowej, skoro przekraczają siły i pojemność rozumu. Może jednak chodzi tu głównie o to, jak one przebiegają i czy normalna gra procesów fizjologicznych jest zachowana? Zresztą przeczytam odpowiedź Ks. kan[onika] Bogdanowicza i napiszę, co o niej sądzę.

Tymczasem kończę me uwagi, by przede wszystkim J[ego] Ekscelencji, Najczcigodniejszemu Ks. Arcybiskupowi złożyć wyrazy synowskiego oddania i życzyć zachowania sił i zdrowia tak dla dobra dusz polskich niezbędnego

Stefan Dąbrowski

47 Osoba niezidentyfikowana.

48 Bądzyński Stanisław (1862-1929), biochemik, 1906-1919 prof. chemii na Wydziale Lekarskim UJK we Lwowie, w roku akad. 1907/08 i 1916/17 dziekan fakultetu, 1919-1929 prof. Wydziału Lekarskiego Uniwersytetu Warszawskiego. W. Wojtkiewicz-Rok, Wydziat Lekarski, w: Academia militans, s. 810-811.

${ }^{49}$ S. Dąbrowski, B. Dehryng, Z. Stolzmann, Sur les limites de précision de la constante d'excrétion uréique (constante d'Ambard) dans l'examen de la fonction rénale, Cracovie 1937.

${ }^{50}$ Łac.: uprzedzając fakty, z góry. 


\section{Dokument 18}

Kopia: AFKDOPW, teczka 128: Spuścizna abp. Józefa Teodorowicza, sygn. 370/216 [6], List abp. Józefa Teodorowicza do prof. Stefana Dąbrowskiego, Lwów 8 I 1937 r.

Przezacnya Panie Profesorze!

Ogromnie się ucieszyłem listem Pańskim i cieszę się już naprzód nadzieją na pracę Pana Profesora.

Pan Profesor tak nigdy nic nie mówił o swojej wybitnej naukowej roli, że dopiero innym profesorom zawdzięczam wiadomości o Panu. W każdym razie powołując się na Pana, chciałbym też przytoczyć dzieła Pańskie, podobno znane w Niemczech i wspominane wszędzie w podręcznikach.

To ani słowa ładna przemiana! Pan próbował mnie nawrócić na politykę, czego niech Panu Bóg nie pamięta, a tymczasem kończy się tym, że ja Pana nawracam nawet pro foro externo ${ }^{51}$ do jego zawodowej znakomitej pracy. A tak o doktora Deutscha zupełnie się nie lękam. Jest to zarozumialec, arogant a przede wszystkim niefachowy człowiek. Jest on operatorem i specjalistą chorób kobiecych, który nie od dzisiaj dyszy nienawiścią do Konnersreuth, wyrażając się o nim: „ein gotteslasterlicher Betrug”52.

Deutsch jest prostym oszustem: mianowicie ja wyraźnie się zastrzegłem, że zupełnie się nie mieszam do orzeczeń lekarskich o stanach jej chorób i uzdrowień. Tylko jeden wypadek podkreśliłem jako nadzwyczajny, a mianowicie nagłe uzdrowienie głębokich ran jakie miała na nodze stwierdzonych przez lekarza ordynującego.

Tymczasem Deutsch postawił rzecz tak, jak gdybym ja pozytywnie wyrażał moje opinie lekarskie i zniekształcając w ten sposób i fałszując na wzór Siwka teksty mojej książki, z triumfem je zbija. To oszustwo oczywiście za pomocą tekstów będzie mu wykazane.

Posyłam Panu moją pracę i Pan się poorientuje w rozdziale „Die Nahrungslosigkeit”. Wolałbym, ażeby zamiast ustępu ks. Bogdanowicza jako niefachowego była praca Pańska, która istotnie zrobi furorę, zwłaszcza skoro Pan opisze swój własny eksperyment.

Prosiłbym jednak, przynajmniej tymczasowo, po zużytkowaniu o zwrot mojej książki, zanim sobie sprowadzę ją od Pusteta ${ }^{53}$. Co do źródeł fachowych lekarskich o mojej książce, to posyłam Panu artykuły w odpisie z „Etudes Carmelitaines”, w których o mojej książce pisze lekarz paryskiego instytutu; może Pan cały ustęp tej krytyki fachowego i znanego lekarza paryskiego przedstawić kardynałowi.

Na razie tyle. Łączę przy tej sposobności dla Przezacnych Państwa jeszcze raz moje życzenia, które popieram modlitwą zwłaszcza o Pańskie zdrowie, zawsze oddany.

Lwów, dnia 8 stycznia 1937

a Tekst pisany na dwóch stronicach papieru formatu A4. Brak autografu autora pisma. Niżej datacji nota ołówkiem obcą ręką: „Prof. Dąbrowski - Poznań”.

${ }^{51}$ Łac.: na rzecz działań zewnętrznych.

${ }^{52}$ Niem.: bluźniercze oszustwo.

${ }^{53}$ Skrót myślowy dotyczący Wydawnictwa Antona Pusteta w Salzburgu. 


\section{Dokument 19}

Oryg.: AFKDOPW, teczka 139: Spuścizna abp. Józefa Teodorowicza, sygn. 1313/365 [5], List prof. Stefana Dąbrowskiego do abp. Józefa Teodorowicza, Puszczykowo Stare 27 I 1937 r.

27 I 1937, Puszczykowo Stare k/Poznania

Najprzewielebniejszy ${ }^{\mathrm{a}}$ Ks. Arcybiskupie!

Najmocniej przepraszam, że dotąd nie odpisywałem, lecz jestem zajęty redakcją terminowej pracy dla Akad[emii] Umiejętności w Krakowie i dopiero w przyszłym tygodniu zabiorę się do przeczytania całego przysłanego mi materiału. Zapytuję przy tym najuprzejmiej, w jakim terminie moja spisana opinia ma być przysłana?

Ostatnie 10 dni były u nas przykre: zima bez śniegu, mróz $15^{\circ} \mathrm{C}$ połączony z gwałtownym wiatrem ze wschodu. Muszę nawet przebywać $\mathrm{w}$ domu z powodu zaziębienia, które już mija.

Podobno Ojciec św. powiedział w swej chorobie, że „jeden lekarz wystarczy, by mógł umrzeć", ale lekarza nie zmienił. Nie mogę wyjść z podziwu, że ci koledzy włoscy zalecili masaż na skrzepy świeżej daty i okłady gorące! Sam przeszedłem te rzeczy w żyłach - skrzepy zakaźne - i uważam, że tego rodzaju terapia jest prostym przestępstwem. Zresztą Pius $\mathrm{XI}^{54}$ nigdy nie chorował i nie umie chorować. Ks. Prymas mówił mi, że jedyny raz, kiedy położył się do łóżka z gorączką przeleżał szereg dni w Polsce za swej nuncjatury w czasie, czy też po plebiscycie górnośląskim. Wtedy miał wiele udręki z powodu trudności na G[órnym] Śląsku i one Go zmogły - mówił Ks. Prymas.

A ja sobie pomyślałem, czy też do tej udręki nie przyłączyła się także podróż Ks. Biskupa Sapiehy ${ }^{55}$ i J[ego] Ekscelencji Ks. Arcybiskupa J[ózefa] Teodorowicza w sprawie, aby wbrew zaleceniom ówczesnego nuncjusza duchowieństwo górnośląskie brało udział w plebiscycie? Ostatecznie i polityka może zmóc najtęższy organizm.

Łączę wyrazy najgłębszej czci i synowskiego oddania

Stefan Dąbrowski

\section{Dokument 20}

Oryg.: APANP, sygn. P III - 116, teczka 86, List abp. Józefa Teodorowicza do prof. Stefana Dąbrowskiego, Lwów 1 II 1937 r.

Przezacny ${ }^{\mathrm{a}}$, Kochany Panie Profesorze!

Dziękuję Panu Profesorowi za list ostatni; jeżeli pyta mnie Pan Profesor o termin, to oczywiście prosiłbym o jak najrychlejszy. Z odpowiedzią dłużej zwlekać nie można, bo

\footnotetext{
a Tekst pisany czarnym atramentem na 1,5 stronicy papieru formatu A4.

${ }^{54}$ Zob. w niniejszej publikacji: J. Wołczański, Listy abp. Józefa Teodorowicza do abp. Józefa Bilczewskiego, dokument 130.

${ }_{55}$ Tamże, dokument 2.

a Tekst pisany czarnym atramentem na 1,5 stronicy papieru formatu A4.
} 
już dookoła Deutscha zaczyna się kupićb radykalny odłam lekarzy; chcą bowiem pod jego sztandarem iść w bój, oczywiście przede wszystkim przeciw mej książce, ale właściwie uderzając na Konnersreuth.

Z pracą ks. Bogdanowicza zechce Pan Profesor postąpić jak będzie uważał za stosowne; sądzę, że najlepiej byłoby użyć tę pracę jako materiału do właściwego opracowania Pana Profesora. To byłby całkiem inny prestiż Pana Profesora, znanego dobrze w Niemczech, no i uczonego, który się może powołać i na swe doświadczenia właśnie w odniesieniu do głodu.

Punctum saliens ${ }^{56} \mathrm{w}$ pracy ks. Bogdanowicza są jego tabele sporządzone na podstawie tez dr. Heermanna, które sobie przyswaja Deutsch. Dr Heermann jest specjalistą chorób ucha, a chcąc się wybić zaczął na gwałt studiować u dr. Hohna wpływ głodu na organizm, o ile ten się ujawnia w chemicznych składach. Wtedy Hohn, jego przygodny nauczyciel, wystąpił przeci jego tezom opierając się na doświadczeniach i wnioskach Junkersdorfa $^{57}$ i Liesenfelda ${ }^{58}$. Otóż te prace (Junkersdorfa i Liesenfelda) przesyłam w dosłownym odpisie Panu Profesorowi.

Ks. Bogdanowicz próbuje w swej pracy sprowadzić ad absurdum ${ }^{59}$ tezy Heermanna a więc i Deutscha za pomocą tabel, które sam ułożył. Jakkolwiek jest on laikiem, to wywody jego byłyby niezwykle cenne, bo są wprost druzgocącym argumentem tezy Deutscha i Heermanna; zwracam więc na ten punkt szczególniejszą uwagę Pana Profesora.

Posyłam Panu Profesorowi obok odpisu z archiwum Pflügera ${ }^{60}$ także książkę Morgulisa „Hunger und Unterernährung” ${ }^{1}$, a z pracy Deutscha cały ustęp, który się tą kwestią u Teresy Neumann ${ }^{62}$ zajmuje. Ustępu z Deutscha nie potrzebuje Pan Profesor zwracać, a książkę i przepisaną pracę zwróci mi Pan Profesor dopiero po zużytkowaniu.

Jeszcze raz bardzo gorąco polecam tę sprawę, którą kładę na sercu Panu Profesorowi i łączę dla Państwa jak zawsze bardzo serdeczne i bardzo oddane wyrazy mojej czci

+ Teodorowicz ${ }^{\mathrm{c}}$

Lwów, dnia 1 lutego 1937

W książce zapewne dobrze znanej Panu Profesorowi [... $]^{\mathrm{d}}$ (tutejszy uniwersytet ją ma; zakład farmakologiczny) jest II Bd., str. 438 dyzertacja ${ }^{e}$ o głodzie - najnowszej literatury za to brak.

b Zapis zgodny z oryginałem; tu: skupiać się, gromadzić się.

${ }^{56}$ Lac.: punkt główny, zasadniczy.

57 Osoba niezidentyfikowana.

58 Osoba niezidentyfikowana.

59 Łac.: do niedorzeczności.

${ }^{60}$ Osoba niezidentyfikowana.

${ }^{61}$ S. Morgulis, Hunger und Unterernährung, Berlin 1924.

${ }^{62}$ Zob. w niniejszej publikacji: J. Wołczański, Korespondencja abp. Józefa Teodorowicza z abp. Adamem Stefanem Sapiehą, dokument 91.

c Autograf czarnym atramentem ręką abp. J. Teodorowicza.

d Tytuł w j. niemieckim nieczytelny.

e Forma zgodna z oryginałem; powinno być: dysertacja. 


\section{Dokument 21}

Oryg.: APANP, sygn. P III - 116, teczka 86, List abp. Józefa Teodorowicza do prof. Stefana Dąbrowskiego, Lwów 19 II 1937 r.

Kochany ${ }^{a}$ Panie Profesorze!

Lwów, dnia 19 II 1937 r.

Posyłam jeszcze jedną rzecz, o której myślałem, że już ją Pan Profesor dostał. Boję się tylko, czy się Pan Profesor zanadto nie kłopocze tą sprawą mają[c] zajęcia inne.

Mnie się wydaje, że wystarczyłoby tu krótkie naukowe uzasadnienie:

1-o, że Dr Hohn miał zupełną rację twierdząc, że taka mała zawartość uryny, jaką wykazała się u Teresy Neumann dwutygodniowa obserwacja musiałaby spowodować jej śmierć i że Teresa nic o tym nie wiedząc, a znowu najściślej pod tym względem kontrolowana nie mogła przecież przez te 14 dni dopuścić się umyślnie jakiegoś oszustwa.

2-o, że analiza Dr. Heerman[n]a nie uzupełnia zupełnie tych rezultatów wiedzy, jakie dała obserwacja Junkersdorfa i Liesenfelda, która istotnie, jak pisze Dr Hohn, wykazała, że właściwie „Hungerurin ${ }^{\prime 63}$ nie istnieje. Mogłoby to być poparte jeszcze jakimiś najnowszymi pracami.

Piszę o tym nie by dawać jakieś wskazówki Panu Profesorowi, ale by Jemu ewentualnie uprościć całe zadanie. Pan Profesor zrobi ostatecznie to, co uważa za najistotniejsze i najlepsze. Praca właściwie jest już ukończona tylko czeka jeszcze na pracę Pana Profesora.

b-Najserdeczniejsze wyrazy mej czci dla obojga Państwa

† Teodorowicz ${ }^{-b}$

\section{Dokument 22}

Oryg.: AFKDOPW, teczka 139: Spuścizna abp. Józefa Teodorowicza, sygn. 1314/365 [5], List prof. Stefana Dąbrowskiego do abp. Józefa Teodorowicza, Puszczykowo Stare 2 III 1937 r.

Puszczykowo k/Poznania, 2 marca 1937

Najprzewielebniejszy ${ }^{\mathrm{a}}$ Ks. Arcybiskupie!

Sprawa głodu Teresy z K[onnersreuth] nie jest łatwą i bodaj przede wszystkim wymaga nader obiektywnego rozbioru faktów z punktu widzenia przyrodniczego. Dlatego trzeba być doskonale udokumentowanym nie tylko na podstawie nowszej literatury z tego zakresu, lecz i przede wszystkim na podstawie własnych badań, bo nic nie może zastąpić w tym zakresie praktyki laboratoryjnej i zapoznania się z trudnościami technicznymi i metodycznymi, jakie spotykamy przy zawsze jeszcze niedoskonałych metodach badań procesów rozkładu białka ustrojowego.

\footnotetext{
Tekst pisany maszynowo z wyjątkiem ostatniego zdania na jednej stronicy papieru formatu A4.

Niem.: skąpomocz towarzyszący głodówce.

b-b Nota czarnym atramentem ręką abp. J. Teodorowicza.

a Tekst pisany czarnym atramentem na trzech stronicach papieru formatu A4.
} 
Na 22-marca zgłosiłem na posiedzenie Polskiej Akad[emii] Umiej[ętności] pracę, którą od lat mam w tece, a którą wykonałem w lwowskiej pracowni prof. Stanisława Bądzyńskiego razem z mym przyjacielem St[anisławem] Kozłowskim, także nieżyjącym. Jest to II-ie studium nad 2-tygodniowym głodem jednego z naszych słuchaczy. Pierwsze ogłoszone w 1921 r. w „Bulletin de Chimie biologique”, organie de la Sacrété de Chim[ie]-biol[ogique] de France, dotyczyło „samoczynnego wyjałowienia jelit w czasie głodu", z czego wynika, że już w 4-ym dniu głodówki jelito, zwłaszcza grube, jest prawie bez procesów gnilnych. Obecnie zgłoszona praca jest II-im studium z tego zakresu i dotyczy demineralizacji ustroju oraz stosunku zasad do kwasów wydalanych przez nerki. Trzecie studium, które zgłoszę następnie, dotyczyć będzie przetworów rozpadu białka ustrojowego pod wpływem głodu.

Polemika z D[okto]rem Deutschem zachęciła mnie, aby wydobyć te badania z teki, do której przez wiele lat nie zaglądałem, mając czas zajęty sprawami politycznymi. Zasługą Ekscelencji i Jego książki oraz Ks. prałata Bogdanowicza jest, że tą tekę otworzyłem i zdecydowałem się wyczerpać jej zawartość, ogłaszając moje studia nie tylko w wydawnictwach Polskiej Akad[emii] Umiej[ętności], ale także w „Bulletin de chimie biologique" lub innym czasopiśmie zagranicznym, które jest bardziej czytane.

Co do tego trzeciego studium „o rozpadzie białka w czasie głodówki absolutnej”, to przybyły nowe książki: prof. Terroine'a ${ }^{65}$ ze Strasburga o przemianie [... $]^{\mathrm{b}}-2$ duże tomy, które muszę przeczytać oraz angielskie studium prof. Carlson'a „The Control of Hunger and Thirst in Health and Disease"66, które sprowadzę.

Jeżeli zatem odkładam inne prace, które mam na warsztacie, to jest to zasługą Najdroższego sercu memu Ks. Arcybiskupa. Uprzedzam wszakże, iż te pracowite studia wymagają $[\ldots]^{\mathrm{c}}$ pod względem literatury.

Co do "meritum ${ }^{\prime 67}$, to się nie boję: od tylu lat nic nowego nie znaleziono, gdy cała szkoła prof. Bądzyńskiego przyczyniła się do wykrycia nowych faktów dotyczących "endogennego", więc wewnątrztkankowego rozkładu białka ustrojowego, gdy wszelki dowóz pokarmów ustaje. Dlatego też zgłoszone przeze mnie studia do Ak[ademii] Um[iejętności] zawierać będą nowe oświetlenie procesów przemiany w czasie głodu. Dopiero po tym ogłoszeniu obu studiów przychodzi czas na rozprawienie się z D[okto]rem Deutschem et consortes ${ }^{68}$. Trzeba bowiem mieć za sobą nowy, oryginalny dorobek naukowy, a nie polemizować na podstawie literatury naukowej, często już nieaktualnej lub niedociągniętej do nowych faktów.

Byłbym natomiast przeciwny, aby czy to Ekscelencja, czy to Ks. Prałat Bogdanowicz wdawali się $\mathrm{w}$ polemikę z fizjologii przemiany. Mimo najgłębszej czci, jaką mam dla Ks. Arcybiskupa i podziwu dla głębi Jego myśli oraz uznania dla talentu i pracowitości

\footnotetext{
${ }^{64}$ Właściwie: „Bulletin de la Société de chimie biologique”, Paris 1914-1971.

${ }^{65}$ Osoba niezidentyfikowana.

b Wyraz nieczytelny.

${ }^{66}$ A.J. Carlson, The Control of Hunger and Thirst in Health and Disease, Chicago 1916.

c Wyraz nieczytelny.

${ }^{67}$ Łac.: istoty rzeczy.

${ }^{68}$ Lac.: i towarzyszami.
} 
Ks. prałata Bogdanowicza, nie mogę uznać kompetencji w sprawach fizjologii przezacnych Kapłanów, którym tak jestem oddany.

Jeżeli więc ks. Arcybiskup powie, że wszystko jest gotowe i odpowiedź czeka na moje uzupełnienia, to pozwolę sobie zauważyć przepraszając za moją śmiałą rozwagę, iż ta odpowiedź nie powinna na razie się ukazać. Mamy czas, zwłaszcza, jeżeli Ks. Arcybiskup ma pewność z mej strony, że moje studia nad głodem będące na ukończeniu w ich opracowaniu piórem, bo praca laboratoryjna jest ukończona, ukażą się wkrótce. Może w tych badaniach znajdziemy fakty popierające tezy Ks. Arcybiskupa...

W każdym razie badanie przemiany materii zupełne w ciągu 14-dniowego głodu zajęły nam całą jesień i całą zimę w r[oku] 1913 na 1914. Wyciągnąć syntezę z tych analiz jest rzeczą wymagającą dużego przygotowania i doświadczenia laboratoryjnego, które o ile mnie się wydaje już posiadam w pewnym stopniu.

Taki jest mój plan. Prosiłbym o jego przyjęcie i odłożenie odpowiedzi krytykom-lekarzom na później. Jest to w interesie powagi sprawy i osób w niej zaangażowanych, o których autorytet chodzi mi najmocniej.

Łączę wyrazy głębokiej czci i poważania oraz synowskiego oddania

Stefan Dąbrowski

PS. Streszczenie, które wyślę w marcu do Ak[ademii] Um[iejętności], prześlę J[ego] Ekscelencji. Nie przypuszczałem nigdy, że będę miał tak znakomitego czytelnika prac fizjologicznych! Jestem wdzięczny losowi, który to zrządził.

\section{Dokument 23}

Oryg.: APANP, sygn. P III - 116, teczka 86, List abp. Józefa Teodorowicza do prof. Stefana Dąbrowskiego, Lwów 5 III 1937 r.

Lwów, dn[ia] 5 III 1937

Przezacny ${ }^{\mathrm{a}}$, kochany Panie Profesorze!

Bardzo dziękuję Panu Profesorowi za list ostatni i za nadzieję, że się jeszcze doczekam pociechy z Pana Profesora, oczywiście pod pewnym względem, bo przecież trzymać przez 10 lat pod korcem pracę, która nowe światło rzuca na naukę i zamiast analiz chemicznych badać „dno oka” to naprawdę już aż za dużo. I to jeszcze wtedy, gdy Pana Profesor ma znane nazwisko w kołach naukowych w Niemczech. A więc dzięki Bogu Teresa Neumann budzi Pana Profesora z tego naukowego letargu i ujrzymy pracę z pewnością znakomitą i niesłychanie aktualną. Cieszę się bardzo z tego, a nawet jestem dumny, że właśnie Pana Profesora, który wszystkich Biskupów nawraca, mnie się udało choćby częściowo na dobrą drogę sprowadzić. Tylko ta droga jest jeszcze niestety bardzo daleka i odległa.

a Tekst pisany maszynowo z wyjątkiem jednego fragmentu w tekście i autografu autora na 2,5 stronicach papieru formatu A4. 
Odpowiedź Deutschowi musi się ukazać jak najprędzej, zwłaszcza, że jest już apel Dr. Aignera $^{69}$ do radykalnych kolegów, ażeby stanęli za Dr. Deutschem, jako swoim sztandarem i to właśnie z okazji mej książki. Jakże na to poradzić? Mówiłem o tym z Panem Strońskim. On przyrzekł, że od siebie napisze do Pana Profesora, ażeby pozwolił umieścić swoje nazwisko jako redaktora tej pracy w tym znaczeniu, że Pan Profesor zebrał głosy w tej sprawie. Jeśliby się Pan Profesor na to zgodził, byłbym niezmiernie wdzięczny za to, bo ja swojego nazwiska podpisywać nie mogę i w ogóle do tej odpowiedzi danej Dr. Deutschowi mięszać się nie chcę. To, co napiszę, napiszę pod pseudonimem Verax. Arcybiskup Sapieha mnie ostrzegał, bym na tak arogancki i impertynencki atak pod żadnym warunkiem odpowiedzi nie dawał. Skoro mi to wzbrania, nie ma nikogo by firmować odpowiedź. Ks. Bogdanowicz w Niemczech nie jest znany, zresztą uważają tam, że tu musi odpowiedzieć jakaś powaga lekarska. Kiedy prof. Mager ${ }^{70}$ w Salzburgu dowiedział się o tym, że Ks. Bogdanowicz ma redagować odpowiedź zawołał: „Es ist ein Unglück, dass kein Arzt diese Schrift beantwortet!'

Treść tych rzeczy, które by Pan Profesor niejako pokrył swoją redakcją będzie pod każdym względem, nawet pod względem formalnym, zupełnie pewną w niczym nie przynoszącą ujmy Panu Profesorowi. Tak, jak się dziś rzeczy mają, złożą się na tę pracę: moja odpowiedź (Verax), odpowiedź Ks. Bogdanowicza i specjalisty chorób nerwowych Dra Vitry $^{72}$ z Luxemburgu, ${ }^{\text {b-a może i Dr. Hohna }}{ }^{-b}$.

Chodziłoby jeszcze specjalnie o kwestię artykułu Ks. Bogdanowicza w odpowiedzi Doktorowi Deutschowi, który przysłałem Panu Profesorowi. Otóż ten artykuł, ściśle mówiąc, nie jest artykułem medycznym, jakkolwiek dotyka kwestii medycznych, albowiem w I-szej części wykazuje Ks. Bogdanowicz błąd logiczny w rozumowaniu Deutscha i sprzeczności w nim zawarte nie wchodząc w meritum medycyny, a w II-iej części, również nie wchodząc w meritum medycyny, podkreśla tylko, że sposób tłumaczenia Dr. Deutscha małej ilości uryny u Teresy Neumann nie może być wzięty poważnie w rachubę. Ten artykuł czytał Dr Falkiewicz ${ }^{73}$ we Lwowie, któremu oddano go jeszcze

69 Aigner Eduard - niemiecki lekarz, neurolog, autor prac podważających wiarygodność wydarzeń w Konnersreuth, m.in. Zehn Jahre Konnersreuth, Berlin-Friedenau 1939.

70 Zob. w niniejszej publikacji: J. Wołczański, Korespondencja abp. Józefa Teodorowicza z bp. Henrykiem Przeździeckim, dokument 10.

71 Niem.: nieszczęściem jest, że żaden lekarz nie odpowiedział na to pismo.

72 Właściwie: Witry Théodore (1871-1947), dr medycyny, lekarz luksemburski, specjalista chorób nerwowych w Trewirze, później w Metzu, w 1937 r. osiadł w Luksemburgu; zajmował się zawodowo neuropsychiatrią, zjawiskiem homokseksualizmu i stygmatów, był autorem m.in. prac: Besuch bei Therese Neumann, KSGD, 1934, nr 5, s. 5 ; 1934, nr 46, s. 4 ; 1934, nr 47, s. 4 ; 1934, nr 48, s. 4; Die Resl: Medizinisches aus Konnersreuth (Saarbrücken 1934); Sur les parasites dans la stigmatisation, LM, 1936, nr 2, s. 16-28; Examens médicaux de plusieurs stigmatisées de nos temps, LM, 1936, nr 10, s. 1-38. Źródło: Théodore Witry (Dokter) - Wikipedia, https://lb.wikipedia.org/wiki/Théodore_Witry_(Dokter). Dostęp: 1 I 2017 r.

b-b Fragment ręką abp. J. Teodorowicza.

73 Falkiewicz Antoni (1901-1977), dr medycyny, 1926-1935 lekarz Uniwersyteckiej Kliniki Chorób Wewnętrznych we Lwowie, 1935-1939 prymariusz Oddziału Wewnętrznego Państwowego Szpitala Powszechnego we Lwowie, podczas II wojny światowej przebywał na Rzeszowszczyźnie i w Lublinie, gdzie uzyskał habilitację, od 1945 r. pracował we Wrocławiu: w 1946 r. otrzymał tytuł prof. nadzwyczajnego Akademii Medycznej, w 1961 r. prof. zwyczajnego, w roku akad. 1949/50 dziekan Wydziału Lekarskiego, 1954-1957 
przed wysłaniem artykułu Panu Profesorowi. Powiedział, że jest znakomicie napisany i że ze stanowiska lekarskiego jest zupełnie bez zarzutu. Jeśliby Pan Profesor był także tego zdania, to sytuacja nadzwyczajnie by się uprościła. Pan Profesor bowiem, tak jak sobie rzecz wyobrażam, dałby swoje placet $^{74}$ na wzór cenzury książek duchownych, iż artykuł Ks. Bogdanowicza nie pozostawia żadnych zastrzeżeń. Natomiast w przedmowie wspomni ${ }^{\mathrm{c}-}$ pan profesor ${ }^{-\mathrm{c}}$ o tym, że jako uzupełnienie tej pracy sam przygotowuje osobną pracę o Konnersreuth, że poprzedza ją dwoma artykułami w fachowym piśmie dotyczącymi kwestii przemiany materii w czasie głodu. Tu Pan Profesor musi ogromnie Niemcom zaimponować przypominając się ich dawnej pamięci, a przy tym szafować literaturą i dać szkic swojego przyszłego pomysłu. Wówczas praca Pana Profesora niezłączona z polemiką z Deutschem z natury rzeczy drobiazgową, tylko zyska na tym. Natomiast odpowiedź dana Deutschowi pod redakcją Pana Profesora mając taką zapowiedź zyska ogromnie. Byłby wtedy i wilk syty, i koza cała. A ponieważ żyjemy w czasie, w którym koza pisana przez „z” lub inną literą jest w modzie, wszystko zostanie załatwione w najidealniejszy sposób. Nie jest wykluczone, że Dr Hohn (specjalista od analiz), atakowany przez Dr. Deutscha (specjalisty ${ }^{d}$ od chorób kobiecych), również mu odpisze. Przychodzi mi na myśl, że może by teraz wydać tę część jako I. Tei $7^{75}$, a potem tamtą część jako II. Teil.

Oczekując decyzji Pana Profesora łączę najserdeczniejsze i najoddańsze wyrazy, a dla Pani moje ukłony

† Teodorowicz ${ }^{\mathrm{e}}$

\section{Dokument 24}

Oryg.: APANP, sygn. P III - 116, teczka 86, List abp. Józefa Teodorowicza do prof. Stefana Dąbrowskiego, Lwów 12 V 1937 r.

Przezacny ${ }^{a}$, Kochany Panie Profesorze!

Dziękuję Panu Profesorowi za telegramb i doprawdy żałuję dziś, że tyle ambarasu i kłopotu zrobiłem moją propozycją Panu Profesorowi.

Jak widzę z telegramu, a jak to już wiedziałem z poprzedniego listu Pana Profesora, jest tu zasadnicze nieporozumienie między nami. Niezawodnie musiałem ja zawinić nie dość jasnym przedstawieniem rzeczy. Pan Profesor wychodzi z założenia, jakoby

rektor uczelni, w 1971 r. emeryt; autor prac naukowych z dziedziny internistyki oraz kardiologii. Źródło: Antoni Falkiewicz - Wikipedia, wolna encyklopedia, https://pl.wikipedia.org/wiki/Antoni_Falkiewicz. Dostęp 21 VIII $2017 \mathrm{r}$.

74 Lac.: aprobatę, zgodę.

c-c Fragment ręką abp. J. Teodorowicza.

d Błąd autora; poprawnie: specjalista.

75 Niem.: część.

e Autograf ręką abp. J. Teodorowicza.

a Tekst pisany maszynowo z wyjątkiem autografu autora na dwóch stronicach papieru formatu A4.

b Brak dokumentu. 
w odpowiedzi należało przedstawić cały problem przemiany materii w odniesieniu do Konnersreuth. Tymczasem tak zupełnie nie jest: odpowiedź na zarzuty liczne Deutscha już co do samej formy nie może być rozwlekła i dlatego nie może pomieścić żadnej specjalnej pracy naukowej, na przykład tej kwestii. Przy tym wyraźnie zaznaczyłem w mej książce, że w problemy medyczne nie wchodzę. Zależało mi na tym tylko, ażeby można pomieścić list Pana Profesora jako specjalisty w tych kwestiach, który by stwierdził swoją powagą, że wywód Deutscha przejęty od lekarza uszu dr. Heermanna, przeprowadzony w praktyce prowadzi do absurdu. Pracę w tym kierunku wygotował Ks. Bogdanowicz, którego jednaj nie ma potrzeby nawet nazywać; wywód jego nie jest wcale wywodem medycznym; jest to właściwie przeprowadzenie logiczne konsekwencji [rozumowania] dr. Heermanna. O ile by wywód Ks. Bogdanowicza Panu Profesorowi nie odpowiadał, prosiłbym o odpowiednie poprawki.

Nadmieniłem nadto, że dr Falkiewicz przejrzał dokładnie tę pracę i wyrażając dla niej uznanie w całości ją zaaprobował. Chodziło mi więc przede wszystkim o tego rodzaju list Pana Profesora, w którym Pan Profesor mógł[by] doskonale zaznaczyć i wskazać nowe prace francuskie czy angielskie, a ewentualnie przygotować opinię [publiczną] na nową swoją pracę. Nic ponadto! To zaś wszystko kosztowałoby Pana Profesora jaką[ś] godzinkę czytania.

Ja naturalnie zwlekać ani chwili nie mogę z odpowiedzią; właśnie otrzymałem wiadomość, że pamflet Deutscha drukuje francuska księgarnia wydawnicza w Paryżu. A ja tu przez miesiące zwlekam z odpowiedzią w niemieckim języku! Das bessere ist des Guten Feind ${ }^{76}$.

Spieszę się bardzo i dlatego urywam list, załączając dla Czcigodnych Państwa moje zawsze oddane wyrazy czci głębokiej

† Teodorowicz

Lwów, dnia 12 maja 1937

\section{Dokument 25}

Oryg.: AFKDOPW, teczka 139: Spuścizna abp. Józefa Teodorowicza, sygn. 216/239 [7], List prof. Stefana Dąbrowskiego do abp. Józefa Teodorowicza, Puszczykowo Stare 3 VI 1937 r.

Puszczykowo Stare, dnia 3 czerwca 1937

Najczcigodniejszy ${ }^{a}$ Ks. Arcybiskupie!

Jakże mi było przykro, że nie mogłem przybyć do Lwowa i Stanisławowa na uroczystości jubileuszowe ${ }^{77}$, które tak głośnym i potężnym echem odbiły się w całej Polsce, wskazując skołatanemu społeczeństwu, kto jest właściwym jego kierownikiem duchowym?

\footnotetext{
${ }^{76}$ Niem.: lepsze jest wrogiem dobrego.

a Tekst pisany czarnym atramentem na dwóch stronicach papieru formatu A4. W lewym górnym rogu karty tytułowej firmowy nadruk: „Puszczykowo Stare k/Poznania, tel. 26”.

${ }_{77}$ W 1937 r. abp Teodorowicz celebrował jubileusz 50-lecia święceń kapłańskich. W tym samym roku odbyła się koronacja łaskami słynącego obrazu Matki Bożej w ormiańskim kościele w Stanisławowie.
} 
Jakże blade i sztuczne wydały się różne reklamowane przez prasę i urzędowe agencje osobistości, które powodowane żądzą jedynie władzy usiłują „jednoczyć” to społeczeństwo, które sami przed laty 10-ciu i w ciągu następnego okresu bądź krwawo, bądź bezkrwawo, ale może jeszcze skutecznej i niebezpieczniej rozbijali i demoralizowali. Dlatego uroczystości Stanisławowskie były prawdziwą pociechą dla tych, którzy rozumieją obłudę tego, co się dzieje na powierzchni życia polskiego i tęsknią do powrotu w tym życiu ludzi o wielkich moralnych wartościach.

Na podróż do Stanisławowa miałbym dni $3 \frac{1}{2}-4$ z powodu rozpoczynających się egzaminów. Po moich chorobach jednak muszę się oszczędzać i podróże te w tak krótkim czasie odbyte bardzo by mnie zmęczyły. Wciąż troszczyliśmy się z Zosią ${ }^{78}$, czy Ks. Arcybiskup nie sforsował się w czasie tego obchodu?

Następnie pisałem do Ks. Kan[onika] Bogdanowicza, że w pierwszych dniach lipca odbywa się we Lwowie Zjazd Lekarzy i Przyrodników, na którym będę. Z tego pobytu skorzystam, aby być tam, gdzie będzie Najczcigodniejszy Ks. Arcybiskup i rozmówię się w sprawie Teresy z K[onnersreuth]. Wszelkie korespondencje doprowadzają tylko do nieporozumień i cała ta trudna sprawa winna być załatwiona nasamprzód ustnie. Dlatego na razie nie zabieram głosu w tej sprawie, o której pisałem także do ks. kan[onika] Bogdanowicza, prosząc jeszcze raz i to najusilniej o nieangażowanie się w żadne polemiki. Ostatnie słowo zawsze należy do tych, którzy bez uprzedzeń odnoszą się do przypadków nadnaturalnych, a nie szermują pamfletami i uprzedzeniem, jak to uczynił Dr Deutsch.

Pozwalam sobie przy tej sposobności przesłać Najczcigodniejszemu Ks. Arcybiskupowi moje przemówienie na Akademii 15-lecia Mł[odzieży] Wszechpolskiej ${ }^{79}$, w którym wspominam o podniosłej myśli J[ego] Ekscelencji wypowiedzianej przed laty w Poznaniu.

Łączę wyrazy głębokiej czci i synowskiego oddania

St [efan] Dąbrowski

\section{Dokument 26}

Oryg.: AFKDOPW, teczka 139: Spuścizna abp. Józefa Teodorowicza, sygn. 1312/365 [5], List prof. Stefana Dąbrowskiego do abp. Józefa Teodorowicza, Raba Wyżna 28 VII 1937 r.

Sobota, 28 VII 1937, Raba Wyżna ${ }^{80}$, Dwór

Ekscelencjo ${ }^{a}$, Najdostojniejszy Ks. Arcybiskupie!

Gdy wczoraj wróciliśmy z Rabki ${ }^{81}$, okazało się, że Zosia miała już 38,5 stopnia gorączki bez szczególniejszych objawów. Siedząc u Ks. Arcybiskupa ${ }^{82}$ miała lekkie dreszczyki,

${ }_{78}$ Odniesienie do żony prof. Dąbrowskiego - Zofii.

79 S. Dąbrowski, Do młodzieży narodowej. Przemówienie [...] Kuratora Młodzieży Wszechpolskiej na Uniwersytecie Poznańskim, wygłoszone na Akademii w jej piętnastolecie dnia 2 maja 1937 r., MNa, 1937, nr 20, s. 307-309.

${ }^{80}$ Raba Wyżna - wieś w Polsce południowej k. Nowego Sącza nad rzeką Rabą.

a Tekst pisany czarnym atramentem na 1,5 stronicy papieru formatu A4.

${ }^{81}$ Rabka - znany kurort w Polsce południowej w Kotlicie Rabczańskiej.

${ }^{82}$ Nawiązanie do wizyty Zofii i Stefana Dąbrowskich złożonej abp. Teodorowiczowi bawiącemu wówczas w Rabce. 
o których nic nam nie mówiła i dopiero przed apteką stanęła, aby napić się jakiegoś alkoholu dla rozgrzania. Noc była nieszczególna. Ale myślę, że wielkich rzeczy z tego nie będzie.

Niezmiernie cieszę się, że mogłem parę razy być u Najprzewielebniejszego Ks. Arcybiskupa, a co więcej, że mogłem uzgodnić moje sumienie naukowe z Jego poglądami w tak trudnej sprawie, jaką jest cały proces „Konnersreuth”. Jak się z tego zadania w rzeczy samej zdołam wywiązać, to inna sprawa. Gdy ułożę i przemyślę tekst listu, to oczywiście prześlę go do „Cenzury” lwowskiej.

Bardzo mi ciążyła ta różnica zdań z Jego Ekscelencją i doprawdy nie przypuszczałem, że mogła ona zajść. Martwiłem się szczrze tą rozbieżnością i trzeba było zbiegu okoliczności, aby móc ją usunąć.

Cieszę się ze znacznej poprawy w wyglądzie Jego Ekscelencji i proszę najgoręcej ten zapas sił zaoszczędzić, unikając niepotrzebnych ich wydatków. Zbyt są one bezcenne dla Kościoła i Narodu, aby Jego Ekscelencja mógł je jedynie uważać za swoje własne.

Łączę wyrazy głębokiej czci i synowskiego oddania

Stefan Dąbrowski

PS. Zosia przyłącza swoje wyrazy najgłębszego poważania i oddania.

\section{Dokument 27}

Oryg.: APANP, sygn. P III - 116, teczka 86, List abp. Józefa Teodorowicza do prof. Stefana Dąbrowskiego, [Rabka] 31 VII 1937 r.

Przezacnya Panie Profesorze!

Dziękuję za list Pański i bardzo się cieszę nadzieją, iż się niedługo z Państwem [z]obaczę. Tu bowiem pozostaję jeszcze przez parę tygodni.

Z serdecznymi i oddanymi wyrazami dla Państwa

[Rabka], 31/VII [1]937

† Teodorowicz

\section{Dokument 28}

Oryg.: AFKDOPW, teczka 139: Spuścizna abp. Józefa Teodorowicza, sygn. 1311/365 [5], List prof. Stefana Dąbrowskiego do abp. Józefa Teodorowicza, Raba Wyżna 14 VIII 1937 r.

14 VIII 1937, Raba Wyżna, Dwór

Ekscelencjo ${ }^{a}$, Najdostojniejszy Ks. Arcybiskupie!

Będę w Rabce w poniedziałek $\mathrm{z}$ rana, aby zdać sprawę z przeczytanych materiałów niemieckich. Przypuszczam, że nie będę Ks. Arcybiskupowi przeszkadzał. Owszem,

a Tekst pisany czarnym atramentem ręką nadawcy na kartoniku wielkości biletu wizytowego lub pocztówki.

a Tekst pisany czarnym atramentem na jednej stronicy papieru formatu A4. 
gotów jestem zawsze najchętniej zastąpić braciszka w jego dla Ekscelencji usługach ${ }^{83}$, a wobec tego być troskliwym jako domownik.

W ogóle chcę wykorzystać resztę swego urlopu i w Rabce co drugi dzień przybywać na jakieś kąpiele i zabiegi hytroterapeutyczne, których brak tutaj silnie odczuwam. Będziemy mogli wobec tego z Ekscelencją ustalić pewne punkty widzenia dotyczące T[eresy] $\mathrm{N}$ [eumann] oraz ustalić taki tekst mego orzeczenia, który byłby dla stron obu do przyjęcia.

Łączę wyrazy głębokiej czci i synowskiego oddania

St [efan] Dąbrowski

\section{Dokument 29}

Oryg.: APANP, sygn. P III - 116, teczka 86, List abp. Józefa Teodorowicza do prof. Stefana Dąbrowskiego, [Rabka] 24 VIII 1937 r.

[Rabka], 24/VIII [1]937

${ }^{a}$ Arcybiskup Teodorowicz ${ }^{-a}$. Wyjeżdżam ${ }^{\mathrm{b}} \mathrm{w}$ poniedziałek. Mam nadzieję [z]obaczyć się jeszcze z Panem profesorem, posyłam Ewalda ${ }^{84}$, a proszę o dokumenty $[. . .]^{c}$. Zawsze oddany.

\section{Dokument 30}

Oryg.: AFKDOPW, teczka 139: Spuścizna abp. Józefa Teodorowicza, sygn. 1310/365 [5], List prof. Stefana Dąbrowskiego do abp. Józefa Teodorowicza, Puszczykowo Stare 12 IX 1937 r.

\section{Najczcigodniejszy Ks. Arcybiskupie,}

Puszczykowo Stare ${ }^{85}$, dnia 12 września 1937

Otrzymałem odpis i spieszę odpowiedzieć, dlaczego dotychczas milczę. Oto po powrocie do domu 2-go bm. w nocy zasłabłem na jakieś objawy ze strony serca zapewne w związku z zajęciem gardła, że prof. Jezierski ${ }^{86}$, który do mnie przyjechał, kazał siedzieć w domu i odczekać na uspokojenie się objawów, co ustąpiło dopiero od paru dni.

${ }^{83}$ Aluzja do posługi brata zakonnego przy abp. Teodorowiczu.

a-a Nadruk firmowy.

b Tekst pisany czarnym atramentem na awersie karty wizytowej. Brak miejsca wystawienia dokumentu.

${ }^{84}$ Ewald Gottfried (1888-1963), niemiecki neurolog i psychiatra, profesor medycyny na Uniwersytecie w Getyndze. Kierował zespołem medycznym prowadzącym badania Teresy Neumann w 1927 r. Ewald Gottfried, w: DBE, Bd. 3, herausg. von W. Killy, München 1996, s. 197.

c Wyraz nieczytelny.

${ }^{85}$ Puszczykowo Stare - miejscowość w Wielkopolsce k. Poznania, miejsce zamieszkania rodziny Zofii i Stefana Dąbrowskich.

a Tekst pisany czarnym atramentem na dwóch stronicach papieru formatu A4. W lewym górnym rogu karty tytułowej firmowy nadruk: „Puszczykowo Stare k/Poznania, tel. 26”.

${ }^{86}$ Jezierski Wincenty (1874-1945), dr nauk medycznych, 1903-1909 pracownik klinik w Szwajcarii i Wrocławiu, 1909-1918 kierownik oddziału wewnętrznego prywatnej lecznicy ss. Elżbietanek w Poznaniu, 
Wszakże, nie zajmując się tematem, który omawialiśmy wspólnie w Rabce, czasu nie marnowałem, bo przerobiłem bardzo ciekawe studium eksperymentalne badaczy amerykańskich ( z r[oku] 1923 w „Journal of Brolagreal Chemistry”) nad dziećmi, które dotknięte epilepsją były głodzone do 2-tygodni, a to w celu bądź zniesienia, bądź zmniejszenia ilości ataków. To studium wykonane w Johns Hopkins University ${ }^{87}$ na koszt Epilepsy Medical Research Found jeszcze bardziej umocniło mnie w poglądach, że badacze T[eresy] Neumann, nie mówiąc już o Dr. Deutschu, nie stoją na wysokości wiedzy współczesnej i nawet w tych warunkach, w jakich kontrolę głodu przeprowadzono można było osiągnąć pewne wyniki i bardziej miarodajne wnioski.

W tej chwili braciszkowie przynieśli mi list Ekscelencji z dn[ia] 9-go bm. Bardzo zań dziękuję i postaram się mimo moich zajęć napisać także odpowiedź na zapytanie autora przyszłej odpowiedzi D[okto]rowi Deutschowi. Przypominam, że autor winien kierować do mnie takie mniej więcej zapytanie:

1) „Czy Pan Profesor uważa, że badania, dokonane nad przemianą materii u Teresy N[eumann] mogą obiektywnie potwierdzić jej stan bezpokarmowy?", albo:

2) „Czy Pan Profesor znajduje, że dotychczasowe badania nad przemianą materii u Teresy N[eumann] mogą być wystarczającym kryterium stałego nieprzyjmowania przez nią pokarmów i napojów?"

Treść mej odpowiedzi byłaby, że istotnie częściowym kryterium mogą być, ale jeżeli chodzi o kryteria bezwzględne w całej rozciągłości zjawisk fizjologiczno-chemicznych, to należałoby uciec się do nowoczesnych metod (amerykańskich np.) zamiast prowadzić jadowite polemiki.

Może Ekscelencja zechce inaczej sformułować pytania? Uwagi w znanej sprawie w całej rozciągłości podzielam i zrobię z nich należyty użytek.

Łączę wyrazy głębokiej czci i synowskiego oddania

St[efan] Dąbrowski

\section{Dokument 31}

Oryg.: AFKDOPW, teczka 139: Spuścizna abp. Józefa Teodorowicza, sygn. 1309/365 [5], List prof. Stefana Dąbrowskiego do abp. Józefa Teodorowicza, Puszczykowo Stare 19 IX 1937 r.

Puszczykowo Stare, dnia 19 września 1937

Najczcigodniejszya Ks. Arcybiskupie!

w 1919 r. mianowany ordynatorem oddziału wewnętrznego Szpitala Miejskiego w Poznaniu, 1920-1939 prof. Wydziału Lekarskiego Uniwersytetu Poznańskiego, w roku akad. 1927/28 dziekan fakultetu, 19391945 lekarz w Słupcy. F. Łabendziński, Jezierski Wincenty, w: PSB, t. 11, red. zbior., Wrocław-Warszawa-Kraków 1964-1965, s. 213-214.

${ }^{87}$ Johns Hopkins University - prywatny uniwersytet amerykański w Baltimor, stan Maryland, założony w $1876 \mathrm{r}$.

a Tekst pisany czarnym atramentem na dwóch stronicach papieru formatu A4. W lewym górnym rogu karty tytułowej firmowy nadruk: „Puszczykowo Stare k/Poznania, tel. 26”. 
Pomimo nawału pracy egzaminacyjnej i związanej z przyjmowaniem nowych słuchaczy na Wydział lekarski, nie zapominam o mojej obietnicy i pracuję nad sprawą Teresy Neumann.

Przeczytałem całą odpowiedź Ks. kanonika Bogdanowicza, a także pracę doświadczalną fizjologów z Boune ${ }^{88}$ nad głodem 40-dniowym Saceo $\mathrm{II}^{89}$ i Mia ${ }^{90}$. Z odpowiedzi ks. kanonika jako z materiału skorzystałem, ale odpowiedź jego nie jest i oczywiście nie może być dość fachowa i autorytatywna, aby mogła mocno uderzyć w D[okto]ra Deutscha, o którym nabrałem najgorszego wyobrażenia. Ale i co do pracy obu fizjologów niemieckich miałbym pewne zastrzeżenia natury fachowej o tyle, że mała ilość acetonu i ciał pokrewnych u Saceo II wynika stąd, że ten głodomór zapijał się po prostu wodą mineralną i w ten sposób zobojętniał reakcję moczu aż do odczynu obojętnego, co stoi w wewnętrznym związku z obecnością jedynie śladów ciał acetonowych. „Mia”, kt[óra] piła mniej, miała wydalany mocz kwaśniejszy, a ponieważ była to dziewczyna dość tłusta, więc materiału na acetonowe związki było więcej niż u Saceo. Niemniej zdanie autorów niemieckich jest słuszne, że tak jak rozmaita jest stopa i nasilenie przemiany materii indywidualnej w stanie zdrowia, to zmienność tej stopy „á forters” jest większe w głodzie.

Na potwierdzenie tego słusznego poglądu znalazłem w literaturze amerykańskiej u P.A. Shaffera ${ }^{91}$ („Journ[al] of Biolog[ical] Chemisty”, vol. I i IV str. 4 i 5) przypadek i to $\mathrm{z}$ literatury niemieckiej cytowany („Brugsel Zeitschr[ift] [...] Path[ologie] und Ther[apie]", 1905, [str.] 4 i 9) b[ardzo] wychudzonej kobiety ze zwężeniem przełyku zupełnym, która z musu była na głodzie absolutnym, a u której tzw. „ketoris”, tj. wytwarzania związków acetonowych nie było prawie zupełnie! Ten fakt tłumaczy Shaffer tym, że chora ta więcej niż u innych głodujących spalała białka, co stwierdzono, kosztem którego powstający cukier spalał się, a w jego „ogniu” utleniały się ciała acetonowe, jak to właśnie bywa normalnie. Jest to przykład stanowczo bardziej klasyczny, niż Saceo i Mia u fizjologów z Boun.

Cały więc zarzut D[okto]ra Deutscha i polemika o aceton nie jest „argumentum cruciales $^{\prime 92}$, bo może być, a może i nie być. Tyle na razie uwag co do kwestii acetonu, o który Ks. Arcybiskup nalegać raczył w Rabce.

Łączę wyrazy czci i oddania

St [efan] Dąbrowski

\footnotetext{
${ }^{88}$ Miejscowość niezidentyfikowana.

${ }^{89}$ Osoba niezidentyfikowana.

${ }^{90}$ Osoba niezidentyfikowana.

${ }^{91}$ Osoba niezidentyfikowana.

b Wyraz nieczytelny.

92 Łac.: decydującym argumentem.
} 


\section{Dokument 32}

Oryg.: APANP, sygn. P III - 116, teczka 86, List abp. Józefa Teodorowicza do prof. Stefana Dąbrowskiego, Lwów 21 IX 1937 r.

Przezacny ${ }^{\mathrm{a}}$, Kochany Panie Profesorze,

Lwów, dnia 21 września 1937 r.

Niezmiernie jestem zobowiązany za obydwa listy, a ucieszyłem się ogromnie listem ostatnim, z którego widzę, że Pan Profesor jest już zupełnym panem przedmiotu i że go oświetli z właściwej i nowej strony. W ogóle praca Pańska będzie bombą w uczonych Niemczech. Cieszę się nią nie tylko ze względu na samą pracę i na Osobę Pana Profesora, jak i na to, że Polak da tu nauczkę dumnej niemieckiej wiedzy.

Dlatego proszę bardzo już nie żałować czasu i pracy, i mimo trudności co rychlej ją dokończyć. Myślę, że dużo już Panu Profesorowi nie brakuje, bo najważniejsza rzecz to ujęcie i rozwinięcie problematu. Proszę też popisać się znajomością najnowszej literatury na tym polu.

Co do kwestii „Überwachung" ${ }^{\text {"थ3 }}$, to jest to trudno pogodzić nową tę „Überwachung”i tę, która się już odbyła, i która żadnych wątpliwości, co do dobrych rezultatów nie pozostawiła. Dlatego przedkładam tekst Biskupa Buchbergera ${ }^{94}$, ordynariusza Teresy Neumann, który w „Leksykonie für Theologie und Kirche” z jednej strony wykazuje, że pierwszy nadzór był bez zarzutu, a z drugiej strony podaje przyczyny, dla których byłby wskazany drugi nadzór. Wyciągam stąd ważniejsze zdania: „[...] Nur für die Zeit dieser Beobachtung ist ein vernűnftiger und berechtigter Zwiefel an der Tatsache der Nahrungslosigkeit nach dem bestimmten Zeigniss der vereidigten, sehr erfahrenen und vőllig verlässigen Beobachtungsschwestern, die Th[erese] N[eumann] keinem Augenblick ellein u[nd] unbeobachtet Giessen, augeschlossen. Der bayerische Episkopat hat 1932 nach gemeinsamen Beschluss an die Familie N[eumann] den Wunsch gerichtet, dass die Fortdauer der absoluten Nahrungslosigkeit durch eine neue, längere Beobachtung in einer Klinik oder Anstalt festgelegt werde, damit allen Zweifeln die Berechtigung genommen werde" ${ }^{195}$.

A więc pierwsza „Überwachung” jest w rezultacie bez zarzutu. Druga (projektowana) zaś jest już pewniejsza, luksusowa, dla odjęcia wszelkich wątpliwości u tych, którzy pomimo dowodów jednak jeszcze wątpią.

a Tekst pisany maszynowo z wyjątkiem autografu autora na 2,5 stronicy papieru formatu A4.

${ }^{93}$ Niem.: kontroli, inwigilacji.

${ }^{94}$ Buchberger Michael (1874-1961), święcenia kapłańskie w 1900 r., od 1906 r. profesor prawa kanonicznego w Uniwersytecie Filozoficzno-Teologicznym w Ratyzbonie, 1923-1928 biskup pomocniczy archidiecezji Monachium i Fryzyngi, 1928-1961 ordynariusz diecezji Ratyzbona. Redaktor 10-tomowej encyklopedii: Lexikon für Theologie und Kirche (Freiburg im Breisgau 1930-1938). Buchberger Michael, w: DBE, Bd. 2, herausg. von W. Killy, München 1995, s. 181.

${ }_{95}$ Niem.: jedynie na czas tej obserwacji wykluczone jest rozsądne i uzasadnione wątpienie w fakt braku odżywiania się, na podstawie pewnego świadectwa zaprzysiężonych, bardzo doświadczonych i godnych zaufania obserwujących sióstr, które nawet na moment nie pozostawiły Theresy Neumann samej i nieobserwowanej. Episkopat bawarski w 1932 roku, po wspólnym postanowieniu, skierował do rodziny Neumann prośbę, aby kontynuowanie absolutnego braku odżywiania zostało ustalone poprzez nową, dłuższą obserwację w klinice bądź zakładzie, aby pozbyć się wszelkich wątpliwości. 
Dlatego bardzo prosiłbym, aby w pracy Pana Profesora była wyraźna wzmianka w duchu tym, jak Pan Profesor mówił w Rabce, że nie ma Dr. Ewaldowi żadnego powodu nie dowierzać, który pierwsze badanie uznał za takie, „które nie ma żadnej luki”.

Nie ma też Pan Profesor powodu niedowierzać enuncjacji Konstystorza regensburskiego opartej o świadectwa Komisji lekarskiej. Dlatego Pan Profesor przyjmuje, że pierwsza „Beobachtung ${ }^{\prime \prime 6}$ była wystarczająca, ale jeżeli kto[ś] chce jeszcze drugiej dla zewnętrznego ujawnienia tego zjawiska wobec świata, to w takim razie musi zadośćuczynić tym warunkom, które oszczędzą potrzebę ponownego badania i oszczędzą wszelkiej udręki osobie badanej.

Jeszcze raz Kochanemu Panu Profesorowi bardzo a bardzo dziękuję i łączę dla Państwa moje zawsze oddane wyrazy głębokiej czci

† Teodorowicz

\section{Dokument 33}

Oryg.: AFKDOPW, teczka 139: Spuścizna abp. Józefa Teodorowicza, sygn. 1308/365 [5], List prof. Stefana Dąbrowskiego do abp. Józefa Teodorowicza, Poznań 28 IX 1937 r.

Poznań, dnia 28 września 1937

Najprzewielebniejszy Ks. Arcybiskupie!

Najmocniej przepraszam za moje opóźnienie w odpowiedzi na ostatni list Ekscelencji. Lecz początek roku szkolnego związany z wstępnymi egzaminami na medycynę licznych kandydatów nastręcza wiele kłopotów i zajęć tak, że sprawa cała marnie utknęła. Mam nadzieję jednak, że wkrótce zabiorę się do pisania co pójdzie tym łatwiej, że uzgodnione zostały zasadnicze punkty, jak to szczególnie wynika z ostatniego listu J[ego] Ekscelencji. Pochwalam zawarte w nim wytyczne i mogę bez wchodzenia w kolizję $\mathrm{z}$ moim sumieniem naukowym zabrać głos w całej tej trudnej sprawie.

W moim zdrowiu, a raczej sercu, zachodzi poprawa, a przyjazd Zosi, która wreszcie wróciła od Stadnickich z Nawojowej ${ }^{97}$ jest tym szczęśliwym wypadkiem w domu, który przyspieszy powrót do sił. Sama Zosia lepiej wygląda, ale jeszcze jest zbyt szczupła.

Sensacją dnia u nas jest dymisja Adolfa Bnińskiego ${ }^{98}$ z prezesury Naczelnego Komitetu Akcji Katolickiej po „Studium katolickim”99, które odbyło się w Warszawie na tematy społeczne. Tak niebezpieczny temat rzeczywiście nie był przygotowany ani uzgodnione

${ }^{96}$ Niem.: obserwacja.

a Tekst pisany czarnym atramentem na dwóch stronicach papieru formatu A4. W lewym górnym rogu karty tytułowej firmowy nadruk: „Dziekan Wydziału Lekarskiego Uniwersytetu Poznańskiego”.

${ }_{97}$ Nawojowa - miejscowość koło Nowego Sącza; majątek hr. Edwarda Stadnickiego i jego żony Heleny Marii z Sapiehów, siostry krakowskiego bp. Adama Stefana Sapiehy.

98 Bniński Adolf Rafał Jan (1884-1942), działacz społeczno-polityczny i katolicki z Wielkopolski, 19221928 wojewoda poznański, 1934-1937 prezes Naczelnego Instytutu Akcji Katolickiej, 1935-1938 senator RP, sympatyk endecji, współzałożyciel Stronnictwea Zachowawczego, 1941-1942 więziony przez Niemców i rozstrzelany. E. Janicka, Bniński Adolf Rafat Jan, w: SKSP, red. zbior., t. 1, Warszawa 1991, s. 38-39; M. Smogorzewska, Posłowie i senatorowie, t. 1, s. 157-158.

${ }_{99}$ III Studium Katolickie odbyło się w dn. 5 - 10 IX 1937 r. w Warszawie. 
nie były poglądy prelegentów, z których znaczna część nie wyłączając księży choruje po prostu na radykalizm społeczny. „Kultura” ${ }^{100}$, którą wydaje Ks. Dyr[ektor] Bross ${ }^{101}$ jest opanowana przez prezesów i członków „Odrodzenia” ${ }^{102}$; z nich większość zatrąca marksizmem, nienawiścią do ziemiaństwa etc. Przepowiadałem dawno, że gdy przyjdzie do rozprawy na tematy społeczne, rozbieżności między katolikami będą większe niż pomiędzy stronnictwami politycznymi, które przynajmniej mają więcej realizmu i nie powołują się ciągle na Papieża i Encykliki, w dodatku niewłaściwie interpretowane.

Łączę wyrazy głębokiej czci i synowskiego oddania

St [efan] Dąbrowski

PS. Znany polityk francuski, oddany Polsce Louis Marin ${ }^{103}$ mówił jednemu z moich kolegów z Wydziału prawnego tego lata, że do radykalizacji katolicyzmu w Hiszpanii przyczyniły się fałszywe interpretacje encyklik społecznych Stolicy Apostolskiej, a więc pośrednio, jak mówił, same encykliki...

\section{Dokument 34}

Oryg.: AFKDOPW, teczka 139: Spuścizna abp. Józefa Teodorowicza, sygn. 1307/365 [5], List prof. Stefana Dąbrowskiego do abp. Józefa Teodorowicza, Poznań 9 XI 1937 r.

Poznań, dnia 9 listopada 1937

Najprzewielebniejszy ${ }^{\mathrm{a}}$ Ks. Arcybiskupie!

100 „Kultura. Tygodnik literacki, artystyczny i społeczny” - priodyk ukazujący się w latach 1936-1939 w Poznaniu, 1936-1938 wydawca i redaktor naczelny ks. Stanisław Bross.

101 Bross Stanisław (1895-1982), dr teologii oraz prawa kanonicznego, święcenia kapłańskie w 1919 r. w Gnieźnie, 1930-1938 dyrektor Naczelnego Instytutu Akcji Katolickiej, założyciel i redaktor kilku czasopism katolickich m.in. „Ruchu Katolickiego” i „Kultury”, 1939-1945 więziony przez hitlerowców w Poznaniu, Kazimierzu Biskupim i Dachau, po wojnie pełnił funkcję referenta w sekretariacie Prymasa Polski, 19491962 kanonik Kapituły Katedralnej w Gnieźnie, 1953-1956 wikariusz generalny archidiec. gnieźnieńskiej, 1956-1982 mieszkał we Wrocławiu; autor licznych publikacji o tematyce katolicko-społecznej. Kanonicy Kapituły Katedry Gnieźnieńskiej 1918-2009, red. B. Czyżewski, K. Wętkowski, Gniezno 2010, s. 161-163; F. Galewicz, Bross Stanisław, w: SKSP, t. 1, s. 56-57; M. Damazyn, Nie-ordynariusz gnieźnieński Stanisław Bross, RTHK, 2017, nr 4, s. 133-156.

102 „Odrodzenie” - Stowarzyszenie Katolickiej Młodzieży Akademickiej; organizacja młodzieżowa istniejąca $\mathrm{w}$ Polsce $\mathrm{w}$ okresie międzywojennym w ośrodkach uniwersyteckich, celem miało być formowanie polskiej inteligencji w duchu religii katolickiej. Wybitni członkowie m.in.: A. Chaciński, ks. Aleksander Fedorowicz, ks. Władysław Korniłowicz, Karol Górski, Stefan Swieżawski, Jerzy Turowicz, ks. Stefan Wyszyński. Wydawano kilka czasopism: „Prąd”, „Odrodzenie”, „Dyszel w głowie”, Nurty” i in. Po II wojnie światowej działalność uległa zawieszeniu, dopiero od 1957 r. organizowano w Częstochowie coroczne zjazdy seniorów „Odrodzenia”. P. Nitecki, „Odrodzenie”. Stowarzyszenie Katolickiej Młodzieży Akademickiej, w: EK, t. 14, red. zbior., Lublin 2010, kol. 345-346.

${ }^{103}$ Marin Louis (1871-1960), polityk i podróżnik francuski, współzałożyciel w 1903 r. Federacji Republikańskiej, w 1934 r. minister zdrowia i wychowania fizycznego, 1934-1936 i w 1940 r. minister stanu; założył periodyk „La Nation”, podczas II wojny światowej zaangażowany w ruch oporu, w 1945-1946 członek Zgromadzenia Ustawodawczego. Źródło: Louis Marin (politician), Wikipedia, https://en.wikipedia.org/wiki/ Louis_Marin. Dostęp: 1 I 2017 r.

a Tekst pisany czarnym atramentem na 1,5 stronicy papieru formatu A4. W lewym górnym rogu karty tytułowej firmowy nadruk; „Dziekan Wydziału Lekarskiego Uniwersytetu Poznańskiego”. 
Istotnie, że cierpliwość J[ego] Ekscelencji wystawiona jest na poważną próbę, gdyż rękopis w sprawie Konnersreuth powinien być od dawna gotów. Jednakże moje liczne, zbyt liczne zajęcia tak odrywały mnie od pracy, iż przez 2 pierwsze miesiące nie miałem naprawdę czasu ani też dosyć sił, aby podołać wszystkiemu. Dopiero teraz tempo zajęć dziekańskich nie jest tak gorączkowe i pozwoli mi spokojniej patrzeć w najbliższą przyszłość. Więc postawmy sprawę tak: rękopis przyślę Ekscelencji w listopadzie, nie oznaczając terminu kiedy. Ale proszę mi wierzyć, że zrobię wszystko, aby rzecz tę przyspieszyć.

Czytałem na okładce w „La Vie Intellectuelle”104, dwutygodnika Dominikanów, który abonuję, po raz pierwszy ogłoszenie francuskie rozprawy $\mathrm{D}$ [okto]ra Deutscha z poleceniem od redakcji. Czy nie byłoby najwłaściwiej odpisać Deutschowi na tę broszurę w języku francuskim?

Ten tekst, który mam przysłać, ma być w języku niemieckim. Czy jednak na rozprawę francuską Deutscha, która nie jest drukowana jako rękopis, lecz faktycznie jest w handlu, nie należało odpowiedzieć w tej samej drodze i w tym samym języku?

Poddając tę myśl rozwadze Jego Ekscelencji, proszę przyjąć wyrazy najgłębszej czci i oddania

Stefan Dąbrowski

\section{Dokument 35}

Oryg.: AFKDOPW, teczka 139: Spuścizna abp. Józefa Teodorowicza, sygn. 1306/365 [5], List prof. Stefana Dąbrowskiego do abp. Józefa Teodorowicza, Puszczykowo Stare 3 XII 1937 r.

Najprzewielebniejszy ${ }^{\mathrm{a}}$ Ks. Arcybiskupie!

Puszczykowo Stare, dnia 3 grudnia 1937

Jestem najgłębiej zmartwiony, że nie mam gotowego jeszcze tekstu artykułu o Teresie Neumann, o której czytałem, że jest już bliżej Poznania, bo była w Karlsbadzie. Ciekaw jestem, czy czasami nie groziło jej niebezpieczeństwo ze strony Gestapo...

Dnie 26 i 27 listopada, które przeznaczyłem wyłącznie na pracę dla Ks. Arcybiskupa zajęły mi narady w gronie b[ardzo] poważnych ludzi, jak książę Witold ${ }^{105}$, Adam ${ }^{106}$

104 „La Vie Intellectuelle” - francuskie czasopismo dominikańskie ukazujące się w latach 1928-1956, założone przez o. Marie-Vinncenta Bernadota OP na prośbę Piusa XI, przy wsparciu filozofa Jacquesa Maritaina.

a Tekst pisany czarnym atramentem na czterech stronicach papieru formatu A4. W lewym górnym rogu karty tytułowej firmowy nadruk: „Puszczykowo Stare k/Poznania, tel. 26”.

105 Aluzja do księcia Witolda Czartoryskiego. Zob. w niniejszej publikacji: J. Wołczański, Listy abp. Józefa Teodorowicza do abp. Józefa Bilczewskiego, dokument 75.

106 Żółtowski Adam (1881-1958), doktor filozofii, w 1910 r. habilitacja na UJ w Krakowie, po I wojnie pracownik MSZ, uczestnik III Powstania Śląskiego, 1920-1933 kierownik Katedry Filozofii Nowożytnej Uniwersytetu Poznańskiego, 1928-1930 posej na Sejm RP z listy Stronnictwa Narodowego, 1933-1939 mieszkał w majątku żony na Wileńszczyźnie, 1939-1958 przebywał w Londynie, współzałożyciel i dyrektor Polskiego Ośrodka Naukowego tamże. C. B[rzoza], Żóttowski Adam, w: Kto byt kim, s. 490. 
i Leon Żółtowscy ${ }^{107}$, Dziekan Winiarski ${ }^{108}$, ks[iążę] Seweryn Czetwertyński ${ }^{109}$ i paru innych, nie wyłączając b[yłego] prezesa $[. . .]^{\mathrm{b}} \mathrm{p}$ [ana] Joachima $[. . .]^{\mathrm{c}}$. Chodzi mianowicie o to, że na Studium katolickim w Warszawie wypłynęła nie tylko demagogia Ks. Madeya ${ }^{110}$, ale także wielu innych księży, a w dodatku nagle spadła z nieba enuncjacja Rady Społecznej przy Prymasie, zalecająca wywłaszczenie reszty większej własności przez rząd. Krok ten najzupełniej nie na czasie, bo nie w tym zło, że zostało trochę własności większej, ale w bezprawiu i samowoli oraz etatyzacji życia społecznego.

Zosia napisała śmiały artykuł w „Myśli Narodowej” ${ }^{111}$, który Ekscelencji prześle i za który od swego Wuja dostała pochwały. Nieszczęściem jest, że pod kierownictwem Dyrektora Akcji Katolickiej Ks. D[okto]ra Brossa „Kultura” uprawia jawną demagogię i że np. Ks. Dyrektor aprobował w odczycie na Studium katolickim pogląd Ks. Madeya, że „akcja katolicka winna zająć się parcelacją większej własności”, co podchwycili w „Falandze"112 $[\ldots]^{\mathrm{d}}$, gwałtownie zwalczając Zosię za jej artykuł. Całe ziemiaństwo w Wielkopolsce, ale nie tylko ziemiaństwo, jest na Radę Społeczną oburzone i zapytuje, czy Episkopat Polski aprobuje jej poglądy?

Ponieważ na ten rok Nacz[elny] Inst[ytut] Akcji Kat[olickiej] wysunął temat „Sprawa Społeczna”, więc wszyscy prześcigają się w nowych pomysłach, a prym w niedojrzałej demagogii wiodą niektórzy księża, niemrawa $[\ldots]^{\mathrm{e}}$ i „Odrodzenie”. Dość powiedzieć,

107 Żółtowski Leon (1877-1956), ziemianin z Wielkopolski, 1919-1920 naczelnik wydziału i kierownik departamentu w Ministerstwie b. Dzielnicy Pruskiej, 1922-1927 poseł na Sejm RP, związany ze Stronnictwem Chrześcijańsko-Narodowym, od 1927 r. działacz organizacji zawodowych, 1939-1940 więziony przez Niemców w VII Forcie w Poznaniu. C. B[rzoza], Żóttowski Leon, w: Kto byt kim, s. 490.

108 Winiarski Bogdan Stefan (1884-1969), doktor prawa, w 1919 r. członek polskiej delegacji na konferencję pokojową w Paryżu, 1922-1939 prof. prawa międzynarodowego Uniwersytetu Poznańskiego, działał w strukturach Ligi Narodów, 1928-1935 poseł na Sejm RP z listy Związku Ludowo-Narodwego, w 1940 r. dostał się do Anglii, 1961-1964 prezes Międzynarodowego Trybunału Sprawiedliwości w Hadze. C. B[rzoza], Winiarski Bohdan Stefan, w: Kto byt kim, s. 470.

${ }_{109}$ Czetwertyński Seweryn Franciszek (1873-1945), polski arystokrata, ukończył studia ekonomiczne, do 1918 r. przebywał w zaborze rosyjskim: m.in. poseł do Dumy Państwowej, 1919-1935 poseł do Sejmu RP z listy Związku Ludowo-Narodowego i Stronnictwa Narodowego, 1928-1931 wicemarszałek Sejmu, 19411945 więziony przez Niemców, w 1945 r. wyjechał do Anglii, gdzie zmarł. C. B[rzoza], Czetwertyński-Światopetk Seweryn Franciszek, w: Kto byt kim, s. 258.

b Dwa wyrazy nieczytelne.

c Wyraz nieczytelny.

110 Osoba niezidentyfikowana.

111 „Myśl Narodowa” - czasopismo społeczno-kulturalne wydawane w latach 1921-1939 w Warszawie, reprezentujące idee Stronnictwa Narodowego. Redaktorzy w porządku chronologicznym: Józef Wierzejski, Ignacy Oksza-Grabowski, Stanisław Włodek, Jan Rembieliński, Zygmunt Wasilewski.

112 "Falanga” - narodowo-radykalny ruch w II Rzeczypospolitej, dysponujący organami prasowymi: „Falanga”, „Ruch Młodych”, „Ruch Kulturalny”, „Ruch Gospodarczy”, „Kuźnica”. Funkcję przywódcy pełnił Bolesław Piasecki, a działaczami byli m.in.: Władysław Jamontt, Wojciech Kwasieborski, Alfred Łaszowski, Paweł Musioł, Adolf i Marian Reutt, Witold Wincenty Staniszkis, Wojciech Wasiutyński, Wojciech Zaleski.

d Wyraz nieczytelny.

e Wyraz nieczytelny. 
że Dziekan Winiarski mówił mi, iż nasi ekonomiści Taylor ${ }^{113}$, Zaleski ${ }^{114}$ etc. odrzucili artykuł do „Ruchu prawno-ekonomicznego” Ks. rektora Wóycickiego ${ }^{115}$, b[yłego] posła z C[hrześcijańskiej] D[emokracji], którego poglądy uznali za bliskie komunizmu. Na cóż się przydała więc odezwa Ks.Ks. Biskupów na Synodzie w Częstochowie ${ }^{116}$ przeciw $^{2}$ radykalizmowi?

Dziekanowi Winiarskiemu na parę tygodni przed rewolucją i wojną domową w Hiszpanii mówił w Madrycie Arcybiskup tamtejszy, że klęską Kościoła w Hiszpanii było to, że złączył się on z Gil Roblesem ${ }^{117}$, niejako hiszpańskim chadekiem, zamiast pójść z ruchem narodowym i że radykalizm duchowieństwa doprowadził kraj ten do nieszczęścia.

Coś podobnego zaczyna się u nas. Rada Społeczna przy Prymasie w składzie ludzi nie mających pojęcia o realnych stosunkach i o sprawie agrarnej, w czasie [... $]^{\mathrm{f}}$ zagrała do poparcia reformy Poniatowskiego ${ }^{118}$, odwracając uwagę od tego, że najniższe warstwy ludowe na pierwszy plan wysuwają postulaty polityczne, a nie agrarne. Ks. Biskup Kubina ${ }^{119}$,

113 Taylor Edward (1884-1964), polski ekonomista, 1919-1939 prof. Uniwersytetu Poznańskiego i Akademii Handlowej w Poznaniu, po 1945 r. prof. ekonomii politycznej w Uniwersytecie Łódzkim, twórca tzw. poznańskiej szkoły ekonomicznej, autor m.in. dzieł: Wstęp do ekonomiki (t. 1-2, 1936-1938), Teoria produkcji (1947), Historia rozwoju ekonomiki (t. 1-2, 1957-1958).

114 Zaleski Stefan (1888-1959), doktor prawa, w 1925 r. habilitacja, 1925-1938 prof. Wydziału Prawno-Ekonomicznego Uniwersytetu Poznańskiego, 1929-1931 dziekan fakultetu, 1938-1949 prof. ekonomii politycznej Wydziału Prawa Uniwersytetu Warszawskiego, 1945-1946 dziekan fakultetu, w roku akad. 1946/47 prorektor uczelni, 1953-1959 prof. Wydziału Nauk Ekonomicznych UW. Autor m.in. prac.: Wptyw maszyn na bezrobocie wg pogladów ekonomistów XIX wieku (1935), Organizacja naukowa (1939), Teoria i polityka płac (1939). Profesorowie Wydziału Prawa i Administracji Uniwersytetu Warszawskiego 1808-2008, red. G. Bałtruszajtys, Warszawa 2008, s. 181-183.

115 Wóycicki Aleksander (1878-1954), święcenia kapłańskie w 1901 r. w Warszawie, duszpasterz kilku parafii, doktor nauk politycznych i społecznych, 1909-1918 prof. Akademii Duchownej w Petersburgu, 19181924 prof. socjologii oraz ekonomii gospodarczej KUL, 1924-1939 prof. chrześcijańskiej nauki społecznej na Uniwersytecie Stefana Batorego w Wilnie, 1937-1939 rektor uczelni, 1922-1927 poseł do Sejmu RP z listy Chrześcijańskiej Demokracji, 1934-1939 członek Rady Społecznej przy Prymasie Polski, okres II wojny spędził w Warszawie, po 1945 r. prof. socjologii na Wydziale Teologicznym Uniwersytetu Warszawskiego i Seminarium Duchownego w Warszawie. Autor m.in. prac: Socjalizm a religia (Poznań 1920), Chrześcijański ruch robotniczy w Polsce (Poznań-Warszawa 1921), Demokracja chrześcijańska w Polsce (Petersburg 1918).

S. Gajewski, Wóycicki Aleksander, w: SBKSwP, t. 3, s. 193.

116 I Synod Plenarny miał miejsce w dniach 26-28 VIII 1936 r. w Częstochowie.

117 Gil-Robles y Quiñones de León José María (1898-1980), hiszpański adwokat i polityk, dr prawa, działacz katolicki, członek prawicowych formacji politycznych.

f Wyraz nieczytelny.

118 Poniatowski Józef Maria ((1897-1973?), absolwent studiów rolniczych, 1918-1920 służył w Wojsku Polskim, 1930-1935 poseł do Sejmu RP z listy BBWR, od 1936 r. dyrektor Biura Ekonomicznego Prezydium Rady Ministrów, do 1939 r. wykładowca geografii gospodarczej w Wyższej Szkole Dziennikarskiej w Warszawie, po 1945 r. przebywał w Anglii, m.in.wykładowca 1948-1950 w Polish University College w Londynie. K. Stepan, Poniatowski Józef Maria, w: Kto byt kim, s. 400.

119 Zob. w niniejszej publikacji: J. Wołczański, Korespondencja abp. Józefa Teodorowicza z abp. Adamem Stefanem Sapieha, dokument 82. 
Ks. rektor Szymański ${ }^{120}$, Ks. rektor Wóycicki, Ks. Dyrektor Kozłowski ${ }^{121}$ (Szkoła Społeczna w Poznaniu), Ks. Dr Piwowarczyk ${ }^{122}$, Ludwik Górski ${ }^{123}$ i prof. Caro ${ }^{124}$ - oto skład tej Rady.

Ks. Prymas jest chory, ale mimo to przyjął mnie. Powiedziałem Mu tylko tyle, że wydaje mi się krok Rady Społ[ecznej], jako angażujący Ks. Prymasa i cały Episkopat bez należytej kompetencji Rady w materii poruszanej, nie jest na czasie i budzi poważne wątpliwości. Trudno było mówić więcej w sprawie tak drażliwej i w dodatku Eminencji w czasie choroby. Ale nie kryję przed Ekscelencją obaw, że tego rodzaju polityka nie jest polityką, ale dolewaniem oliwy do ognia. Jesteśmy tym wszyscy poruszeni, a głównie z tego powodu, że koncepcja „funkcji społecznej” własności w interpretacji Rady Społecznej i Ks. Bisk[upa] Kubiny [... $]^{g}$ samą własność indywidualną. A wówczas gdzie granica między zasadą własności a kolektywizmem, korporacjonizmem a kołchozami?

Tak tedy te naglące sprawy zajęły mi całe dwa dni, które wśród mych rozlicznych zajęć wykroiłem sobie dla Ks. Arcybiskupa. Ale w myśl przysłowia: „a l’impossible nul n'est tenu” ${ }^{\prime 25}$, nie byłem w możności zrobić inaczej.

Łączę dla Ks. Arcybiskupa wyrazy głębokiej czci i oddania

Stefan Dąbrowski

${ }^{120}$ Szymański Antoni (1881-1942), święcenia kapłańskie w 1904 r. we Włocławku, dr filozofii, 1908-1918 wykładowca filozofii i nauk społecznych w Seminarium Duchownym we Włocławku, 1918-1939 prof. polityki społecznej KUL, w 1919 r. habilitacja, w roku akad. 1920/21 dzielan Wydziału Prawa Kanonicznego, 1931/32 dziekan Wydziału Prawa i Nauk Społeczno-Ekonomicznych, 1922-1925 prorektor KUL, 19331942 rektor uczelni, wybitny organizator studiów i mecenas modernizacji gmachów uniwersyteckich, autor publikacji z dziedziny katolickiej nauki społecznej. C. Strzeszewski, Szymański Antoni, w: SBKSwP, t. 3, s. $118-120$.

121 Osoba niezidentyfikowana.

122 Piwowarczyk Jan (1889-1959), święcenia kapłańskie w 1910 r. w Krakowie, dr teologii, duszpasterz i katecheta tamże, 1936-1939 redaktor naczelny „Głosu Narodu”, członek Chrześcijańskiej Demokracji oraz Rady Społecznej przy Prymasie Polski, kanonik gremialny Kapituły Metropolitalnej w Krakowie, 1945-1951 redaktor naczelny „Tygodnika Powszechnego”, publicysta i dziennikarz katolicki, autor m.in. prac: Sprawa włościańska a Polskie Stronnictwo Chreścijańskiej Demokracji (1926), Wspótczesne stosunki społeczne (1926), Katolicyzm a reforma rolna (1937). C. Strzeszewski, Piwowarczyk Jan, w: SBKSwP, t. 2, red. zbior., Warszawa 1994, s. 192-193.

${ }^{123}$ Górski Ludwik Kazimierz (1894-1945), dr nauk ekonomicznych, w 1926 r. habilitacja z ekonomii politycznej, 1924-1939 prof. na Wydziale Prawa i Nauk Społeczno-Ekonomicznych KUL, w roku akad. 1928/29 dziekan fakultetu, członek Rady Społecznej przy Prymasie Polski, autor m.in. prac: Tomistyczna doktryna własności (1935), Problem przeludnienia na tle struktury agrarnej (1930), Wytyczne programu wiejskiego w świetle zasad katolickich (1937). C. Strzeszewski, Górski Ludwik Kazimierz, w: EK, t. 5, red. zbior., Lublin 1989, kol. 1389.

${ }^{124}$ Caro Leopold (1864-1939), dr prawa, 1894-1914 adwokat krakowski, 1920-1939 prof. ekonomii społecznej i nauk prawniczych Politechniki Lwowskiej, 1923-1939 prof. ekonomii Uniwersytetu Jana Kazimierza we Lwowie, członek Rady Społecznej przy Prymasie Polski, autor m.in. prac: Sadownictwo w sprawach agrarnych (1908), Prawdy i prawa w naukach społecznych (1921), Problem społeczny w katolickim oświetleniu (1935). E. Hauswald, 50 lat życia ekonomicznego. Księga pamiątkowa ku czci ś.p dra Leopolda Caro, Prezesa Polskiego Towarzystwa Ekonomicznego i profesora ekonomii Politechniki Lwowskiej, Lwów 1939, s. IX-XVII; C. Strzeszewski, Caro Leopold, w: EK, t. 2, red. zbior., Lublin 1985, kol. 1341-1342.

g Wyraz nieczytelny.

${ }^{125}$ Fr.: nikt nie jest zobowiązany do rzeczy niemożliwej. 


\section{Dokument 36}

Oryg.: APANP, sygn. P III - 116, teczka 86, Telegram abp. Józefa Teodorowicza do prof. Stefana Dąbrowskiego, Lwów 6 XII 1937 r.

\section{Telegram Nr 94}

Profesor Dąbrowski, Puszczykowo

Przyjęto dnia 6/12 1937, godz. $10 \mathrm{~min}[\mathrm{ut}] 08$

z Poznania

z Lwów 6, nr 85, słów 19, dn[ia] 6/12, godz. 8 min[ut] 50

${ }^{a-M o j e ~ z o b o w i a ̨ z a n i a ~ w o b e c ~ w y d a w n i c t w ~ n i e ~ p o z w a l a j a ̨ ~ n a ~ d a l s z e ~ z w l e k a n i e, ~ p r o s z e ̨ ~}$ raczej skrócić ale wysłać zaraz ${ }^{-a}$.

b-8/XII [19]37 Arcybiskup Teodorowicz Lwów. Tekst polski gotów, po przepisaniu prześlę Ekscelencji. Czy mam zrobić przekład niemiecki. Deutsch położony na obie łopatki $[\ldots]^{-\mathrm{b}}$.

\section{Dokument 37}

Oryg.: AFKDOPW, teczka 139: Spuścizna abp. Józefa Teodorowicza, sygn. 1305/365 [5], List prof. Stefana Dąbrowskiego do abp. Józefa Teodorowicza, Puszczykowo Stare 10 XII 1937 r.

Puszczykowo Stare k/Poznania, dn[ia] 10 XII 1937 r.

Ekscelencjo ${ }^{a}$, Najdostojniejszy Księże Arcybiskupie,

W tej chwili skończyłem dyktować moją rozprawę p.t.: „Paradoksalny metabolizm w przypadku Teresy Neumann z Konnersreuth". Jutro egzemplarz zostanie wysłany Ekscelencji z łaskawą prośbą przeczytania go uważnego i porobienia odpowiednich notatek oraz poprawek. Jeżeli we Lwowie będzie robione tłumaczenie niemieckie, to prosiłbym uprzejmie o przysłanie mi go do przejrzenia, zarówno jak i korekt $\mathrm{t}^{126}$.

Równocześnie proszę Ekscelencję, aby zechciał tekst mojej rozprawki dać do przeczytania Panu Dziekanowi W[łodzimierzowi] Koskowskiemu ${ }^{127}$ i prosić go o surową ocenę.

Nadto przesyłam projekt „słowa wstępnego”, które wydaje mi się jak najbardziej odpowiednim wprowadzeniem in medias res ${ }^{128}$.

W końcu najgoręcej przepraszam za zwłokę i udręczenia, które nią sprawiłem. Pomijam chorobę we wrześniu i ogrom zajęć dziekańskich. Ale umysł mój pracuje powoli i sprawa wydawała mi się niedojrzałą. Aż dziwne, jakem się do tego zabrał: w święto

a-a Tekst pisany ołówkiem.

b-b Tekst pisany czarnym atramentem ręką S. Dąbrowskiego.

a Tekst pisany maszynowo na 1,5 stronicy papieru formatu A4. Jeden z autografów sporządzony czarnym atramentem, drugi maszynowo.

126 AFKDOPW, teczka: Spuścizna abp. Józefa Teodorowicza, bsygn., S. Dąbrowski, Paradoxer metabolismus im Falle der Therese Neumann von Konnersreuth, bmr, ss. 18, mps.

127 Zob. w niniejszej publikacji: J. Wołczański, Korespondencja abp. Józefa Teodorowicza z abp. Andrzejem Szeptyckim, dokument 34.

128 Łac.: w sedno sprawy. 
Matki Boskiej 8 września zbudziłem się nad ranem z gotową koncepcją i w jeden dzień napisałem całą rozprawę. Po prostu znalazłem klucz do tego zjawiska, nie wchodząc $\mathrm{w}$ konflikt z moim sumieniem naukowym i zamiłowaniem do materialnych faktów dobrze ustalonych.

Zanoszę do Ekscelencji jeszcze jedną prośbę: proszę nie dołączać mojej rozprawy do polemiki z Dr. Deutsch'em, nad którą zrywa sobie system nerwowy zarówno Ekscelencja, jak i jego współpracownicy. Polemika ta wydaje mi się nie ma miejscu i jest zbyt zaszczytna dla Dr. Deutscha. Moja rozprawa kładzie go na obie łopatki w najważniejszym punkcie. Dlatego proszę gorąco, żeby ta rozprawka była osobno wydrukowana jako nowy przyczynek do Konnersreuth. Nadto chciałbym rzecz tę później wydać w języku francuskim i sam zrobiłbym ten przekład.

Przy tej sposobności łączę wyrazy czci i synowskiego przywiązania dla Ekscelencji, które sprawiło głównie, że tej pracy się podjąłem i doprowadziłem ją do końca.

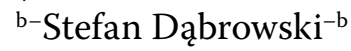
${ }^{c-}\left(\right.$ Stefan Dąbrowski) ${ }^{-c}$

\section{Dokument 38}

Oryg.: AFKDOPW, teczka 139: Spuścizna abp. Józefa Teodorowicza, sygn. 1304/365 [5], List prof. Stefana Dąbrowskiego do abp. Józefa Teodorowicza, Puszczykowo Stare 12 XII 1937 r.

Puszczykowo Stare, dnia 12 grudnia 1937

Najczcigodniejszy ${ }^{a}$ Ks. Arcybiskupie!

Załączam moją rozprawkę ${ }^{129}$ o Teresie Neumann z okresu, gdy była poddana badaniom prof. Ewalda. Żadna praca nie kosztowała mnie tyle kłopotu jak właśnie ta, którą Najczcigodniejszemu i Dostojnemu memu Przyjacielowi obiecałem wykonać a to w celu, by nie dopuścić do zakłamania przypadku niezwykłego, jakim jest sposób życia T[eresy] $\mathrm{N}$ [eumann].

Tekst pisany od jednego rzutu wymaga jeszcze oszlifowania, wykresu krzywych wag głodomorów i T[eresy] N[eumann], który wykona mój starszy chłopiec i dokładnego ustalenia cytat oraz odnośników literatury. Są to tylko poprawki, ale całość jest gotowa. Poddam ją krytyce prof[esora] psychologii Błachowskiego ${ }^{130}$ i fizjologa Zbyszewskiego

b-b Tekst sporządzony czarnym atramentem.

c-c Tekst pisany pismem maszynowym.

a Tekst pisany czarnym atramentem na 1,5 stronicy papieru formatu A4. W lewym górnym rogu karty tytułowej firmowy nadruk: „Puszczykowo Stare k/Poznania, tel. 26”.

129 AFKDOPW, teczka: Spuścizna abp. Józefa Teodorowicza, bsygn., S. Dąbrowski, Paradoxer metabolismus im Falle der Therese Neumann von Konnersreuth, bmr, ss. 18, mps.

130 Błachowski Stefan (1889-1962), dr filozofii, 1914-1919 pracownik naukowy Uniwersytetu Lwowskiego, 1919-1960 prof. i kierownik Katedry Psychologii Uniwersytetu Poznańskiego, 1934-1937 dziekan Wydziału Humanistycznego, w roku akad. 1938/39 i 1945/46 prorektor uczelni, 1946-1948 rektor, pozostawił po sobie ponad 100 prac z dziedziny psychofizjologii, psychologii religii oraz psychologii pamięci. Biogramy uczonych polskich, cz. 1: Nauki społeczne, z. 1: A-J, Wrocław 1983, s. 350. 
Leona ${ }^{131}$, mych kolegów z U[niwersytetu] P[oznańskiego], a także proszę dać do przeczytania prof. Koskowskiemu, który może zechce dać dokładniejsze cytaty swoich prac, które cytuję.

Czy mimo wszystko zadowoliłem Ks. Arcybiskupa? Tego właśnie nie wiem i oczekuję zdania Ekscelencji. Jeżeli ta rozprawka może się Ekscelencji przydać i odpowie zapatrywaniom zasadniczym w tej sprawie, będę to uważał za najlepszą i najmilszą nagrodę osobistą.

Łączę wyrazy czci i synowskiego przywiązania

Stefan Dąbrowski

PS. Nie wiem, co jest trudniejsze, czy obrona Ks. Arcybiskupa przed pamfletami D[okto]ra Deutscha, czy też Eminencji ks. Prymasa przed Radą Społeczną przy Prymasie Polskim?

\section{Dokument 39}

Kopia: AFKDOPW, teczka 128: Spuścizna abp. Józefa Teodorowicza, sygn. 1318/365 [5], Kopia listu abp. Józefa Teodorowicza do prof. Stefana Dąbrowskiego, Lwów 15 XII 1937 r.

Lwów, dnia 15 grudnia $1937 \mathrm{r}$.

Przezacny ${ }^{\mathrm{a}}$ Kochany Panie Profesorze,

Otrzymałem prześliczną i znakomitą pracę Pana Profesora, której niestety zupełnie zużyć nie mogę dla jednego zasadniczego braku. Ten brak polega na tym, że Pan Profesor zdaje się nie doceniać znaczenia i wartości obserwacji i przerzuca całą siłę dowodową co do stwierdzenia niejedzenia i niepicia jedynie tylko na eksperymenta chemiczno-fizjologiczne.

W ten sposób Pan Profesor przekreśla znaczenie dotychczasowe odbytej w r. 1937 dwutygodniowej obserwacji Teresy Neumann, a równocześnie uniemożliwia zupełnie stwierdzenie niejedzenia i niepicia przez ewentualną obserwację przyszłą, albowiem zarówno Biskupi niemieccy, jak i lekarze zaręczyli p[anu] Neumannowi ${ }^{132}$, że obserwacja przyszła ograniczy się jedynie i wyłącznie do badania przez świadków, czy Teresa nie je i nie pije, z wykluczeniem wyraźnym wszelkich zabiegów klinicznych. Jakkolwiek więc poszczególne uwagi Pana Profesora są wprost świetne, to jednak w całości praca Jego przekreśla dotychczasowy owoc badań i wyklucza możliwość badania przyszłego.

Pozwoli pan Profesor przypomnieć sobie, że już w Rabce mówiłem o tym, jak konieczną rzeczą jest uznać możliwość kontroli niejedzenia i niepicia przez prostą obserwację

${ }^{131}$ Zbyszewski Leon (1880-1943), dr medycyny, fizjolog, prof. UJK we Lwowie, później analogicznie Uniwersytetu Poznańskiego. Udział Lwowa i Kresów Potud[niowo]-Wschod[nich] w życiu nauk[owym] i kult[uralnym] Poznania $i$ Wielkopolski. Biogramy i wspomnienia, red. J. Rozmiłowski, Poznań 2007, s. 197-198.

b Forma zgodna z oryginałem; poprawnie: Polski lub polskim.

a Tekst pisany maszynowo na 2,5 stronicach papieru formatu A4. Brak autografu autora. W lewym górnym rogu karty tytułowej nota czarnym atramentem: „Prof. Stefan Dąbrowski, Puszczykowo. Projekt listu”.

${ }^{132}$ Neumann Ferdinand (1873-1959), ojciec Teresy, z zawodu krawiec. 
gdziekolwiek bądź podjętą. To jest stanowisko Ewalda - to jest nawet stanowisko Deutscha, chociaż podchodzą oni do tej tezy każdy w swoim guście. To jest też stanowisko Hohna, który właśnie wykazał, że 2-tygodniowa obserwacja według zdania powag lekarskich wystarczy, by stwierdzić, że „Nahrungslosigkeit ${ }^{\text {”33 }}$ przy nieubywaniu wagi jest dostatecznie udowodnioną. To jest także stanowisko Heermanna, który od przyszłej obserwacji żąda tylko dokładnej kontroli i czułej wagi.

Niesłychanie mi przykro, że muszę tak szczerze Panu Profesorowi napisać jakkolwiek wiem, że Mu to będzie bolesne, ale pod przygniatającym wpływem pierwszego wrażenia nie widzę w ogóle drogi wyjścia. Wszystkie cenne, bystre i świetne uwagi Pana Profesora i znakomite wprost ujęcie naukowe mogłyby pozostać, gdyby było inne założenie zasadnicze, tj. położenie głównego nacisku na kontrolę bez względu na wszelkie kliniczne zabiegi, a te dopuszczone tylko o tyle, o ile dla zaspokojenia ciekawości lekarskiej.

W Pańskiej pracy zarówno Dr Deutsch, jak i Dr Ewald - ten ostatni w swej tezie o klinice neutralnej, która jest tylko rozpaczliwą ucieczką przed faktem obserwacji - muszą znaleźć dla siebie argument.

Bardzo jestem Panu Profesorowi zobowiązany za ten trud i wkład, jaki Pan Profesor poniósł dla mnie i mej pracy. Jest to dla mnie dziś wprost katastrofą to, co się stało.

Z Ks[ięciem] Czartoryskim miałem dłuższą konferencję i niestety zgadzam się we wszystkim z Panami.

Stworzenie Rady Przybocznej przez Prymasa jest przede wszystkim usunięciem was i niesłychanie niebezpiecznym symptomem. Rządzą tą Radą Dr Caro, Ks. Szymański, Ks. Pastuszka ${ }^{134}$ - doktrynerzy bez zupełnego wyczucia obecnych rządów i kryzysów, jakie przechodzimy. Grozi [to] Kościołowi, że może się stać narzędziem nieświadomym w ręku judeo-masonów, którzy przez wysunięcie parcelacji chcą odwrócić uwagę od ekonomicznego bojkotu Żydów.

Jeszcze raz bardzo Kochanego Pana Profesora przepraszam za treść mojego listu i zapytuję, czy Pan Profesor nie mógłby zmienić trochę Swej pracy podając te same myśli $\mathrm{w}$ innej formie.

Łączę bardzo serdeczne i gorące wyrazy mej czci dla Państwa.

${ }^{133}$ Niem.: brak pożywienia.

134 Pastuszka Józef (1897-1989), święcenia kapłańskie w 1919 r. w Sandomierzu, dr teologii oraz filozofii, 1921-1930 wykładowca w Seminarium Duchownym w Sandomierzu, w 1930 r. habilitacja, 1930-1934 wykładowca Wydziału Teologii Katolickiej Uniwersytetu Warszawskiego, 1934-1969 prof. i kierownik Katedry Psychologii na Wydziale Humanistycznym KUL, 1938-1947 dziekan Wydziału Filozoficznego tamże, 19531956 usunięty z uczelni przez władze komunistyczne, po czym powrócił na poprzednie miejsce; wykładał psychologię ogólną, historię filozofii, filozofię religii i psychologię religii, był autorem wielu publikacji naukowych z tych dyscyplin. Z. Chlewiński, Pastuszka Józef, w: EFP, t. 2, red. zbior., Lublin 2011, s. 304-306; informacje własne autora. 


\section{Dokument 40}

Oryg.: AFKDOPW, teczka 139: Spuścizna abp. Józefa Teodorowicza, sygn. 1302/365 [5], List prof. Stefana Dąbrowskiego do abp. Józefa Teodorowicza, Puszczykowo Stare 18 XII 1937 r.

Puszczykowo Stare, dnia 18 grudnia 1937

Najdostojniejszya Ks. Arcybiskupie!

Pisał mi Ks[iążę] Witold ${ }^{135}$, że Ekscelencja nie jest zadowolony z mej pracy rzekomo dlatego, że „nie opieram się przede wszystkim na skonstatowaniu przez dozór zmieniających się parami zakonnic, kontrolowanych przez lekarza, iż żadnego pożywienia do siebie nie przyjmuje". Oczywiście nieważne, czy książę ściśle słowa te powtórzył, ale gdyby tak się stało, to musiałbym wyznać, że zachodzi jakieś nieporozumienie! Przecież właśnie stwierdzam wyraźnie, że nie mogę i nie mam powodu kwestionować sposobu dozoru zalecanego przez prof. Ewalda i Episkopat miejscowy. Opieram się na tym więc, że w ciągu nowego okresu T[eresa] N[eumann] nie jadła i nie piła.

Drugi wniosek mój polega na tym: skoro T[eresa] $\mathrm{N}$ [eumann] nie jadła i nie piła, to $\mathrm{w}$ takim razie jak funkcjonowała przemiana materii, czyli metabolizm w jej ustroju? Wobec fragmentaryczności analiz można wyciągnąć tylko niektóre wnioski. Jakie? Niewątpliwie siostry zakonne umiały ważyć i czyniły to dokładnie. Przebieg wagi był paradoksalny i to w okresie III fazy słabszy, do której cały ten metabolizm należałoby odnieść, skoro przed rozpoczęciem doświadczenia należy przyjąć, że T[eresa] N[eumann] nie przyjmowała pokarmów. Następnie, skoro waga ustroju, jako całości wahała się paradoksalnie, to zadałem sobie pytanie, czy nie będzie paradoksalnego przebiegu w tych poszczególnych zjawiskach przemiany materii, które prof. Ewald zbadał? Ta myśl była kluczem zagadki. Okazało się bowiem ku niemałemu memu zdziwieniu, że ta paradoksalność występuje.

Czy mogę, jako przyrodnik powiedzieć, że to jest „cud”? Myślę, że podstawy do tego wniosku są zbyt kruche, względnie niezupełne ze względu na zbyt krótki okres czasu Überwachung, dość długi wszakże, aby móc pojąć nieprzyjmowanie napojów. Czy mogłem powiedzieć ekstrapolując doświadczenie, że skoro nie je i nie pije przez 14 dni, może ciągnąć to samo przez 10 lat lub przez jeden nawet rok? Absolutnie nie mogę tego powiedzieć.

Wobec tego powiedziałem dosłownie to, co Ks. Arcybiskup napisał w liście swym z dn[ia] 21 września b.r. Cytuję ten ustęp: „Dlatego Pan Profesor przyjmuje, że pierwsza «Beobachtung» była wystarczająca, ale jeżeli kto chce jeszcze drugiej dla zewnętrznego ujawnienia tego zjawiska wobec świata, to w takim razie musi zadośćuczynić tym warunkom, które anulują potrzebę ponownego badania i oszczędzą wszelkiej udręki osobie badanej". Dziś czytam to samo niemal z enuncjacji ordynariatu Biskupiego w Ratyzbonie ${ }^{136}$. Czy może to uczynił ze strachu przed Deutschem?

\footnotetext{
a Tekst pisany czarnym atramentem na dwóch stronicach papieru formatu A4. W lewym górnym rogu karty tytułowej firmowy nadruk: „Puszczykowo Stare k/Poznania, tel. 26”.

135 Odniesienie do księcia Witolda Czartoryskiego.

136 Ratyzbona - miasto w Bawarii, m.in. siedziba diecezji rzymskokatolickiej, w skład której wchodziło Konnersreuth, rodzinna miejscowość Teresy Neumann.
} 
Proszę uprzejmie Ekscelencję o porobienie uwag swych na mym maszynopisie. Łączę wyrazy czci i oddania

St[efan] Dąbrowski

\section{Dokument 41}

Oryg.: AFKDOPW, teczka: 139, Spuścizna abp. Józefa Teodorowicza, sygn. 759/260 [7], Nota prof. Stefana Dąbrowskiego do abp. Józefa Teodorowicza, Puszczykowo Stare 18 XII 1937 r.

Puszczykowo Stare, 18 grudnia $1927^{137}$

PS. Dodaję co następuje:

Wyniki prof. Ewalda nie były ani przez niego, ani też przez jego zwolenników lub przeciwników dokładnie zanalizowane, tj. nie umiano z nich wyciągnąć wniosków.

Wnioski, które wyciągam w moim opracowaniu dowodzą, że był faktycznie głód, a w tym absolutnym głodzie zachodziły niedające się w sposób klasyczny wytłumaczyć głodowe procesy fizjologiczno-chemiczne. Zachodziły one w sposób odbiegający od normy zjawisk tego rodzaju, czyli paradoksalny. Paradoksalność ta wystąpiła co więcej nie tylko w okresie „Überwachung”, lecz również później, bez kontroli, kiedy nawet głodowe symptomy przemiany materii wystąpiły jeszcze jaskrawiej.

Wszystko to jest właśnie kanwą mego opracowania. Dlatego wydaje mi się, że Ks. Arcybiskup dla celu zwalczenia bezwględnych podejrzeń D[okto]ra Deutscha mógłby wziąć to, co posłałem.

S[tefan] D[ąbrowski]

\section{Dokument 42}

Kopia: AFKDOPW, teczka 128: Spuścizna abp. Józefa Teodorowicza, sygn. 1317/365 [5], Kopia listu abp. Józefa Teodorowicza do prof. Stefana Dąbrowskiego, Lwów 20 XII 1937 r.

Lwów, dnia 20 grudnia 1937

Przezacnya Panie Profesorze,

Bardzo dziękuję za przysłaną pracę, którą stosownie do życzenia Pana Profesora oddałem do przeglądnięcia p[anu] Koskowskiemu. Ze stanowiska naukowego robi ona nawet na laiku wrażenie pracy znakomitej. Nie przesądzam, co powie o niej p[an] Koskowski, z którym się nie widziałem i nie mówiłem. Dochodzą mnie tylko słuchy, że praca Pana Profesora podoba się jemu. Jeśli by jednak praca ta miała się okazać jako pomoc dla mej książki, to musiałoby się to stać przy pewnych wyjaśnieniach, dopełnieniach

137 Błędna data roczna; poprawnie winno być 1937.

a Tekst pisany czarnym atramentem na jednej stronicy papieru formatu A4.

a Tekst pisany maszynowo na pięciu stronicach papieru formatu A4. Brak zakończenia i autografu autora. W lewym górnym rogu karty tytułowej nota czarnym atramentem: „Prof. Stefan Dąbrowski, Puszczykowo. Projekt listu". 
i zmianach, o których uwzględnienie Pana Profesora gorąco proszę. Te zmiany w niczym nie naruszają - moim zdaniem - naukowego sumienia Pana Profesora. Jeśliby jednak Pan Profesor był innego zdania, w takim razie proszę mi pozwolić jeszcze w ostatniej chwili pójść na próbę inną.

Otóż wyjaśniam stanowisko obecne sprawy Konnersreuth. Ma być podjęta nowa obserwacja Teresy Neumann. Ona jest gotową się jej poddać choćby za wszelką cenę. Jest więc prawdopodobnym, a w każdym razie pożądanym, by do tej obserwacji przyszło. Warunek jednak, jaki Neumann (ojciec jej) stawia, a który już jest przyjęty, w zasadzie polega na wykluczeniu wszelkich badań klinicznych i ograniczeniu obserwacji li tylko do mierzenia wagi i nadzoru, który - jak się wyraził Dr Hynek ${ }^{138}$ - jest raczej w tym wypadku zadaniem detektywa. Zmarły Halban ${ }^{139}$, z którym ongi[ś] o tym mówiłem, powiedział mi: „Tak jak istnienie jednego atomu wystarczy mi, by wywieść stąd istnienie Boga, podobnie wystarcza (policyjna) obserwacja i waga dla stwierdzenia zjawiska nadprzyrodzonego".

Otóż w sprawozdaniu Pana Profesora jest wprawdzie potwierdzenie świadectwa Dr. Ewalda (to nie jest sławny Ewald, ale młody asystent kliniki w Monachium), iż obserwacja była wzorowa, ale cały nacisk kładzie Pan Profesor na kliniczne obserwacje. W ten sposób podważona jest prawda i waga pierwszej obserwacji przez niedocenienie jej zasadniczego znaczenia i jest zastąpienie jej, a nie dopełnienie przez kliniczną analizę. W ten sposób wobec krytyki poprzednich badań klinicznych jako niedostatecznych, Pan Profesor podważa to, co uznane zostało ze strony przeciwnej jako fakt niezbity, co uznał Dr Hohn i wielu innych.

$\mathrm{Z}$ pewnością Pan Profesor tego nie miał na myśli, a nawet wręcz przeciwnie. Ale chcąc wykazać Panu Profesorowi jak się rzecz w praktyce przedstawia i zresztą zgodnie $\mathrm{z}$ nauką, gdyż ona eksperyment obserwacji pierwszej zawsze za główny uznaje, stawiam kropkę nad „i”. Takie stanowisko dla braku dostatecznych określeń zadaje podwójny cios Konnersreuth. Najpierw znaczenie dawnej obserwacji zniża do zera, zaś ewentualną przyszłą obserwację już w szczegółach przygotowaną stawia pod znakiem zapytania, jako nic nieznaczącą bez analiz klinicznych. Tego rodzaju postawienie rzeczy jest sięgające daleko dalej, niż Heermanna i jego ucznia Deutscha. Heermann niczego innego nie żąda od przyszłej obserwacji, jak tylko obserwacji policyjnej i wagi. Deutsch posługuje się kwestią acetonu, jako środkiem do celu, to jest wprowadzenia w wątpliwość poprawności obserwacji pierwszej. O drugiej obserwacji wyraża się mniej więcej w tym samym duchu co Heermann, choć niewyraźnie i nieszczerze. Referat Pana Profesora tymczasem zdaje się uważać samą obserwację i wagę za niewystarczającą z zasadniczych

${ }^{138}$ Hynek Rudolf Maria (1883-1952), pseudonim Ralph Waldo Hynek, czeski lekarz funkcjonujący w Pradze, autor m.in. prac: Konnersreuth im Lichte der ärztlichen und psychologischen Wissenschaft (Prag 1932), Zur Abwehr Neuer Beitrag zur Lösung des Konnersreuther Problems ((Karlsruhe 1938).

${ }^{139}$ Halban Henryk (1870-1933), dr nauk medycznych, w 1903 r. habilitacja, 1905-1933 prof. neurologii i psychiatrii Uniwersytetu Jana Kazimierza we Lwowie, w roku akad. 1914/15, 1915/16 i 1920/21 dziekan Wydziału Lekarskiego, 1927-1933 kierownik Klniki Chorób Nerwowych i Umysłowych we Lwowie. E. Herman, Halban Henryk, w: PSB, t. 9, Kraków 1960-1961, s. 245; W. Rok-Wojtkiewicz, Wydziat Lekarski, w: Academia militans, s. 868-870. 
powodów, o ile mianowicie nie będą użyte zabiegi kliniczne. Ale i Ewald, jeśli apeluje do kliniki neutralnej, to czyni to nie dlatego jakoby uważał, że obserwacja policyjna jest niedostateczna i jakoby ją było potrzeba zastąpić analizą kliniczną. Przeciwnie. On uważa sumienność Sióstr i wagę za tak zasadniczą, że tylko dlatego apeluje do kliniki neutralnej, iż podejrzewa jakąś lukę zasadniczą w sposobie obserwacji. Pan Profesor bierze jego odniesienie się do kliniki neutralnej tymczasem w zupełnie innym znaczeniu aniżeli on to czyni. Przynajmniej tak mi się wydaje. Nie rozumiałbym inaczej co ma znaczyć potwierdzenie tezy o „klinice neutralnej”, która jest ze stanowiska nauki nie do utrzymania, bo dokąd dojdziemy, jeśli naukowe badania będziemy osądzać podług konfesji badających i ich religijnych przekonań, ale przede wszystkim nie rozumiałbym dlaczego Pan Profesor nawet klinikę neutralną uważa za niewystarczającą. Chyba jedynie tylko dlatego, że za mało rękojmi przedstawia dla badań klinicznych, którym Pan Profesor główną rolę przyznaje. Nawet dom szklany jest w obecnym przedstawieniu nie już środkiem do samej obserwacji bez względu na zabiegi chemiczne, ale jest tylko warunkiem wygodniejszym dla obserwacji klinicznych.

Niech mi Pan Profesor nie weźmie za złe mej szczerości, ale czynię to w interesie sprawy i przypisuję takie przedstawienie rzeczy, tak bardzo odbiegające od tego, cośmy mówili w Rabce, jako wywołane brakiem czasu dla sprecyzowania tez. A nikt mi tego nie udowodni, jakoby wykazanie policyjne faktu niejedzenia i niepicia przez miesiąc lub dwa miesiące przy nieobniżeniu się wagi było niewystarczające dla stwierdzenia, iż takie zjawisko przechodzi granice możności zwyczajnej nawet, gdy kliniczne czy chemiczne zabiegi żadnego w tym nie miały udziału. To przecie[ż] jest argument zdrowego sensu, który wiem, że Pan Profesor w pełni uznaje. Ta zresztą zasada w rzeczy samej była podstawą dla wszelkich podobnych badań podjętych przez Kościół. Jest to zasada jedyna, gdyż nauka nigdy nie idzie w poprzek zdrowemu zmysłowi. A więc w tym zasadniczym względzie potrzebuje praca Pana Profesora wyjaśnienia i dopowiedzenia. Zwracałem już na to uwagę w Rabce, potrącając o to w rozmowie z Panem Profesorem.

Z tym wszystkim rozumiem Pana Profesora: w Panu Profesorze odezwał się uczony, dla którego problem Konnersreuth jest pożądanym ze względu na naukę i z tego właśnie stanowiska rzecz biorąc ma Pan Profesor zupełną słuszność, jeżeli taki nacisk kładzie na kliniczne eksperymenty krytykując eksperymenty dawne, a stawiając warunki dla nowych; jednym słowem chce Pan Profesor jako naukowiec zarobić na Konnersreuth i wnieść z tej okazji do badań naukowych nowe światło. Byłoby to stanowisko zupełnie zrozumiałe, gdyby Konnersreuth nie był zarazem problemem religijnym, który nie pozwala przekraczać tych linii wytycznych, jakie przez taki problem są nakreślone. Gdy się bada niejedzenie i niepicie, wystarczy zupełnie obserwacja i waga, co również zaniepokoić musi i każdego człowieka nauki - jak to powiedziałem wyżej.

Ale nie można dla stwierdzenia problemu religijnego dołączać jako warunek sine qua non tych eksperymentów, które jedynie sama wiedzę i jej ciekawość zaspokajają. Jeżeli zaś - jak to Pan Profesor czyni - chce człowiek nauki i o eksperymentacji mającej zaspokojenie ciekawości uczonych na celu, to wolno mu o tym mówić, ale pod tym warunkiem, że się wyraźnie do tego przyzna i wyraźnie powie, że taki eksperyment w badaniu 
zjawisk nadprzyrodzonych nie jest konieczny i niezbędny, że do takiego badania wystarczy sama dobra obserwacja i badanie wagi.

Ażeby praktycznie wyrazić moją konkluzję, ująłbym to, co powiedziałem dotąd w sposób następujący. Pozostawiłbym wszystko w pracy Pana Profesora aż do słów: „ślady ketozy w moczu zanikają" (patrz str. 13). Od tego miejsca należałoby wszystko skrócić i ująć w dwóch punktach:

1) Dotychczasowe badania przeprowadzone pod obserwacją pierwszą (od 14 - 30 VII 1927 r.) dowiodły, że Teresa Neumann nie przyjmuje żadnego pokarmu ani stałego, ani płynnego, co niezawodnie przyczynić się musi do uspokojenia umysłów podejrzewających ją o oszustwa. Zjawisko przechodzące granice możności zwyczajnej stwierdzić się da samą obserwacją, nawet gdyby kliniczne czy chemiczne zabiegi żadnego w tym nie miały udziału. To jest argument zdrowego sensu, który każdy człowiek rozumny uznać musi. Ta zresztą zasada była podstawą wszelkich podobnych badań podjętych przez Kościół. Jest to zasada jedyna, bo nauka nigdy nie idzie w poprzek zdrowemu zmysłowi.

2) Dla zaspokojenia żądzy naukowej i dla ewentualnego wzbogacenia tajników wiedzy lekarskiej, można by dodatkowo przeprowadzić badania kliniczne. (Obserwacja w szklanym domku - kalorymetr respiracyjny - badanie krwi etc.). Te badania mają wszakże w tym wypadku znaczenie tylko uboczne, bo dla stwierdzenia faktu niejedzenia i niepicia zupełnie wystarcza obserwacja i waga. Mam jeszcze dodatkowe wrażenie, że Pan Profesor zbijając Deutscha równocześnie przez krytykę swą zwróconą przeciw Ewaldowi i Hohnowi, właściwie to, co jedną ręką daje, drugą odbiera.

\section{Dokument 43}

Oryg.: APANP, sygn. P III - 116, teczka 86, Kopia listu abp. Józefa Teodorowicza do prof. Stefana Dąbrowskiego, Lwów 24 XII 1937 r.

Lwów, 24 XII $1937 \mathrm{r}$.

Przezacny ${ }^{\mathrm{a}}$, Kochany Panie Profesorze,

Bardzo serdecznie dziękuję Panu Profesorowi za tak piękną - powiem - wprost znakomitą pracę, która się spotkała z pełnym uznaniem takiego znawcy tej kwestii jak p[ana] Koskowskiego. Odnosi się wrażenie czytając pracę Pańską, że właściwie nie tylko już sam płytki Deutsch, ale nawet Ewald i Hohn odbiegają niższością naukową od niveau naukowego, jakie zajął Pan Profesor. Cieszę się z tego niezmiernie ze względu na Osobę Pana Profesora, z którym mnie tak bliskie i bezpośrednie od dawna łączą stosunki, jak również na prestige ${ }^{140}$ polskiej nauki. Poza Hohnem, właściwie zdobyli się Niemcy na jedno: „Schimpfen” ${ }^{\text {”. }}$.

A teraz moje zastrzeżenia, którymi się podzieliłem z Ks[ięciem] Czartoryskim:

a Tekst pisany maszynowo fragmentu na 6,5 stronicach papieru formatu A4 z wyjątkiem zaznaczonego fragmentu.

140 Fr.: prestiż, poważanie.

141 Niem.: obelgi, zniewagi. 
1-o: Aż do strony 13, do zdania zaczynającego się od słów: „Rzecz jasna...” aż do „paradoksu fizjologicznego" przyjąłbym wszystko bez zastrzeżeń, z małą tylko uwagą dopełniającą na stronie 6-tej po zdaniu zaczynającym się od słów: „Rozpatrując” - do „świadczeń". Tu uważałbym za bardzo potrzebne wtrącić takie lub inne zdanie, które by rozgraniczyło to co jest istotne $w$ badaniu to znaczy, że Teresa Neumann istotnie nie je i nie pije, od tego co w tym badaniu stanowi zaciekawienie naukowe. Dlatego proponowałbym takie zdanie, które Pan Profesor według swego najlepszego rozumienia sam skreśli. Mnie zależy na określeniu właściwej myśli w najkrótszych słowach: „Nie są te badania wprawdzie potrzebne dla potwierdzenia prawdy tej tak ściśle przeprowadzonej kontroli, ale byłyby ze stanowiska zainteresowań nauki pożądane”.

2-o: Zdaje mi się, że bardzo słuszne uwagi o „Überwachung” na str. 4 powtarzają się od samej góry na stronie 15. Dlatego przedstawiając to Panu Profesorowi do rozpatrzenia uważałbym za stosowne uwagę na stronie 14-tej przyłączyć i umieścić na stronie 4-tej, aby uniknąć niepotrzebnego powtarzania i wzmocnić twierdzenia na stronie 4-tej.

Co do domku amerykańskiego to proponowałbym inne następujące ujęcie, o ile się Pan Profesor na to zgodzi. Mianowicie: nie chciałbym wystraszać Neumanna tym, że

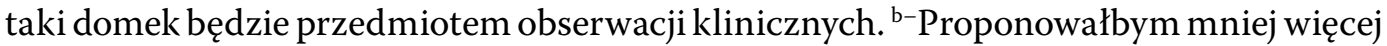
tekst następujący: ${ }^{-b}$ „Pokazało się, że z niektórych kół powstały z tego powodu zastrzeżenia co do 2-tygodniowej obserwacji, iż Teresa Neumann nie zawsze była zamknięta w pokoju, ale także przebywała na wolności chodząc do kościoła. W rzeczy samej te zastrzeżenia okazały się błahe, gdyż obserwacja ścisła Sióstr nie ustawała ani na chwilę tak podczas przebywania jej w pokoju, jak i podczas wychodzenia. ${ }^{\mathrm{c}-Z}$ tego względu uzasadniłbym potrzebę podobnej obserwacji motywami następującymi: ${ }^{-c}$ Ażeby odjąć wszelkim pozorom i zastrzeżeniom podstawę i ażeby przez to samo nie narażać Teresy Neumann na nowe próby obserwacji, proponowałbym zastosowanie systemu używanego w Ameryce (tutaj dokładny opis). ${ }^{\mathrm{d}-T o}$ by można połączyć ze stronicą 4-tą ${ }^{-\mathrm{d}}$.

A teraz przystępuję do właściwych zastrzeżeń. Zaznaczam przede wszystkim, że zupełnie zgadzam się z Panem Profesorem, iż nie może być zamiarem i celem Pana Profesora wykazywanie na podstawie jednej obserwacji, że inne obserwacje byłyby tylko jej powtórzeniem, ani też stwierdzenie cudu. Stwierdzenie cudu nie należy do wiedzy medycznej tylko do teologii, która na podstawie analizy medycznej przychodzi do wniosków takich czy innych.

Co do uwagi Pana Profesora w liście ostatnim, iż się zastosował ${ }^{\mathrm{e}-}$ Pan Profesor $^{-\mathrm{e}}$ do proponowanego przeze mnie rozdziału pomiędzy obserwacją wystarczającą dla stwierdzenia głodu, a znowu zainteresowaniem nauki, to się zgadzam na to najzupełniej i proponowana przeze mnie uwaga do str. 6-tej ma jedynie na celu jaśniejsze właśnie określenie tej właśnie myśli, która tkwi w wywodach Pana Profesora. Zastrzeżenia moje polegają na czym innym: odnoszą się one głownie do ustępu, który się zaczyna

\footnotetext{
b-b Nota ręką abp. J. Teodorowicza.

c-c Tekst skreślony ołówkiem, prawdopodobnie ręką autora listu.

d-d Nota dopisana ręką abp. J. Teodorowicza.

e-e Nota ręką abp. J. Teodorowicza.
} 
na str. 13-tej: „Wiadomo wszakże” aż do str. 14-tej: „zakładu leczniczego było wystarczające". Otóż główny ustęp wyrażający opinię Pana Profesora zaczynający się od słów: "gdy tedy bada” do „wystarczający” przypuszcza jedynie 2 ewentualności w rozwiązaniu problemu paradoksu: jedna to oszustwo, a druga - to dalsze i ściślejsze badanie.

Co do pierwszego punktu, to właściwie Pan Profesor podał już poprzednio te wnioski powołując się na Prof. Ewalda, który wyklucza oszustwo i to co Pan Profesor poprzednio powiedział, jest właściwie załatwieniem tej kwestii i dlatego wznowienie jej w formie całkiem innej uważam za osłabienie tezy poprzedniej Pana Profesora. Bo nie dlatego posądzenie o oszustwo jest czymś ujemnym iż prowadzi do dyskusji „równie zjadliwej, jak bezpłodnej" - co jest motywem podrzędnej wagi - ale tylko dlatego oszustwo jest wykluczone, gdyż zarówno obserwacja, jak i chemiczne zjawiska wykluczają możliwość oszustwa podczas 14-dniowego głodu. Dlatego byłbym w ogóle za wykreśleniem tego ustępu w tym ujęciu, w jakim Pan Profesor z osłabieniem swego stanowiska na stronie 14-tej uczynił.

W tym samym ustępie jest mowa o paradoksie metabolizmu przy nieprzyjmowaniu pokarmów i napojów. Ale ten paradoksalny metabolizm polega też i na tym, co poprzednio Pan Profesor wyraził, iż Teresa Neumann nie je i nie pije, i nie miała umniejszenia wagi.

Otóż stwierdzenie tego stanu rzeczy o ile chodzi o wnioski stąd płynące nie pozwala absolutnie na przypuszczenie, iż przez bardziej rygorystyczne badanie ten paradoks da się może wyjaśnić i dlatego tu przyznaję zupełną rację Prof. Ewaldowi, który wobec tego faktu odniósł się do filozoficznej zasady: „Aus dem Nichts wird nichts”|142. Popadł on wprawdzie w sprzeczność sam ze sobą, bo z jednej strony stwierdził, że obserwacja Sióstr była bez zarzutu, drugiej strony wyraził przypuszczenie, że jakaś luka musiała być w tej obserwacji. Apelował on nawet do takiego nonsensu, jakim jest pojęcie kliniki neutralnej, powiadam nonsensu, bo dokąd byśmy zaszli, gdybyśmy badania kliniczne uzależniali od konfesji tych, którzy je przeprowadzają. Ale to już jest rozpaczliwy czyn człowieka, który stoi wobec faktu wychodzącego poza zakres wszelkiej wiedzy doświadczalnej i eksperymentalnej i w tym znaczeniu docent Ewald (bo to nie jest ten słynny Ewald, o jakim Pan Profesor myśli), ma najzupełniejszą rację. Wobec takiego paradoksu nie można wskazywać na jego rozwiązanie przez ściślejsze badanie. Zmarły Prof. Halban, z którym ongi[ś] o tym mówiłem powiedział mi: „tak jak istnienie jednego atomu wystarczy mi, by wywieść stąd istnienie Boga, podobnie wystarcza (policyjna) obserwacja i waga dla stwierdzenia stanowiska nadprzyrodzonego".

Otóż tu w tym punkcie uważam konkluzję Pana Profesora za niemożliwą do przyjęcia. Przy tym nie ma żadnej analogii pomiędzy paradoksami (p. str. 13 „Wiadome wszakże..."), które się później w naturalny sposób wyjaśniają, a paradoksem, który określa Ewald słowy: „Aufdem Nichts...”"13 itd.

Pomijam już praktyczną stronę kwestii, wiadomą bowiem jest rzeczą, że ojciec Teresy Neumann gdyby się nawet zgodził na obserwację, to wyklucza wszelkie badania

\footnotetext{
${ }^{142}$ Niem.: z niczego nic nie będzie.
}

${ }^{143}$ Niem.: na niczym. 
kliniczne, a Biskup Regensburski w zasadzie z tym jego stanowiskiem się zgadza. Otóż takie stanowisko Pana Profesora nie tylko ze strony przyrodniczej i filozoficznej, ale także ze strony praktycznej nasuwa nieprzezwyciężone trudności.

Tymczasem warunki ułożone w teorii mniej więcej między Biskupem Regensburskim a Neumannem są wystarczającą gwarancją dla stwierdzenia niejedzenia i niepicia, który przechodzi wszelką granicę możliwych tłumaczeń. I nikt mi tego nie udowodni, jakoby wykazanie policyjne niejedzenia i niepicia przez miesiąc lub dwa miesiące przy nieobniżeniu się wagi było niewystarczające dla stwierdzenia, iż takie zjawisko przechodzi granice możności zwyczajnej, nawet gdy kliniczne czy chemiczne zabiegi żadnego w tym nie miały udziału. To przecie[ż] jest argument zdrowego sensu, który wiem, że Pan Profesor w pełni uznaje. Można wprawdzie mówić i w dalszym ciągu o uzupełnieniu badań klinicznych, ale z wyraźnym zastrzeżeniem, że one mają znaczenie tylko uboczne, a zarazem tylko mają na celu ewentualne wzbogacenie wiedzy lekarskiej. Z tego względu proponowałbym opuszczenie ustępu od strony 13-tej: „Wiadomo wszakże” aż do strony 15-tej: „znaną enuncjację Konsystorza Regensburskiego”. W to zaś miejsce proponowałbym streszczenie paradoksów, które Pan Profesor wyliczył w swym badaniu. A więc:

1) Iż Teresa Neumann przez dni 14 będąc pod najściślejszą kontrolą nie jadła i nie piła. Nie jadła więc i nie piła przez przeciąg czasu, który w drodze eksperymentalnej kładzie kres życiu ludzkiemu; górnicy zasypani zazwyczaj wytrzymują bez jedzenia i picia do 8-iu dni; burmistrz z Viterbo wstrzymując się w więzieniu od jedzenia i picia zmarł w 17-tym dniu głodówki.

2) Tak przeprowadzona kliniczna obserwacja potwierdzi obserwację detektywistyczną, tj. stwierdzającą, iż Teresa Neumann przez ten czas nie jadła i nie piła.

3) Najwyższe zaburzenia w organizmie, które występują już po kilku dniach głodówki $\mathrm{w}$ organizmie ludzkim nie istniały wcale $\mathrm{u}$ Teresy Neumann, była ona bowiem w pełni posiadania sił fizycznych, jak i intelektualnych.

4) Ilość wydzielonego przez ten czas moczu u Teresy Neumann była tak małą, iż wedle Dr. Hohna musiałaby wywołać w zwykłych warunkach śmierć.

Na tym prostym stwierdzeniu faktów zamknąłbym właściwy referat. To byłaby główna kwestia, teraz jeszcze parę uwag dodatkowych:

1) Przede wszystkim chciałem zwrócić uwagę Pana Profesora, że cała diagnoza Prof. Ewalda nie jest wcale tak obiektywną, jak by się wydawało: albowiem zarówno w tłumaczeniu przez histerię zjawisk Konnersreuth, jak i w kwestii językowej (w której Ewald rzuca podejrzenie oszustwa na prof. Wutza ${ }^{144}$ ) przedstawia się w pełni jako typowy racjonalista. $Z$ tego względu proponowałbym wyraźne zastrzeżenie ze strony Pana Profesora, iż Pan Profesor nie myśli wchodzić w stanowisko zajęte przez Ewalda wobec tych przejawów u Teresy Neumann, które nie są w związku z przemianą materii. Może z tych względów pewien superlatyw w pochwałach dla Ewalda należałoby obniżyć zwłaszcza, że Pan Profesor właściwie bardzo surowo go krytykuje.

${ }^{144}$ Wutz Franz Xaver (1882-1938), święcenia kapłańskie w 1907 r. w Eichstätt (Niemcy), dr teologii, od 1911 r. prof. Starego Testamentu w Kolegium Filozoficzno-Teologicznym w Eichstätt. J. Franke, Wutz, Franz Xaver, w: BBB, herausg. von K. Bosl, Regensburg 1983, s. 865. 
2) Pan Profesor adresuje do mnie list. Ja jednak absolutnie nie mogę figurować w tej kwestii. Wydawcą tej książki jest Dr Radło ${ }^{145}$. Prosiłbym więc Pana Profesora by odpowiadał na jego zaproszenie wystosowane do Pana Profesora w tej kwestii.

3) Rozumiem to dobrze, że Pana Profesora należy odseparować od samej dyskusji i rozprawy z Dr. Deutschem. Uczyniłem to $w$ tej formie, że w tytule samym podzieliłem tę rozprawę na dwie części: pierwszą częścią jest rozprawa z Deutschem, a całkiem osobna jest część druga (Zweiter Teil), a tą jest rozprawa Pana Profesora; w ten sposób Pan Profesor zupełnie jest poza nawiasem dyskusji polemicznej. Nie mógłbym sobie absolutnie wyobrazić pomocy z rozprawy Pana Profesora, tak wydatnej i istotnej w tej odpowiedzi, gdyby rozprawa Pana Profesora miała wyjść osobno. Musiałbym to uważać wprost za katastrofę dla mnie, gdyż książka pozbawiona tego atutu traci na znaczeniu naukowym, a znowu już jest za późno podejmować próbę z kim[ś] innym, który by Pana Profesora - chociaż nieudolnie nawet - mógł zastąpić. To zupełnie to samo, jak gdyby ktoś z pierścienia w którym jest osadzony brylant, ten brylant wyrzucił. Oczywiście z samej rozprawy pomieszczonej w książce może być zrobiona odbitka, ale jeszcze nie umiałbym sobie wyobrazić książki pozbawionej pracy Pana Profesora.

Kończę już i tak przydługi list nadmieniając, iż co do treści polemiki z Deutschem miał ją w rękach Dr med. Hynek z Pragi, znany pisarz, który się wyraża o niej mówiąc: "Die Replike an Dr. Deutsch ist einfach glänzend"146.

Przy tej sposobności przesyłam dla Państwa bardzo serdeczne i oddane życzenia świąteczne i Noworoczne wraz z wyrazami głębokiego szacunku i poważania

$\mathrm{f}-\mathrm{\dagger}$ Teodorowicz

Wobec nagłości proszę Pana Profesora o największy pośpiech w odpowiedzi i przysłanie brakującej jeszcze tabeli-f ${ }^{-f}$

\section{Dokument 44}

Oryg.: AFKDOPW, teczka 139: Spuścizna abp. Józefa Teodorowicza, sygn. 1301/365 [5], List prof. Stefana Dąbrowskiego do abp. Józefa Teodorowicza, Puszczykowo Stare 31 XII 1937 r.

Puszczykowo Stare, dnia 31 grudnia 1937

Najprzewielebniejszy ${ }^{\mathrm{a}}$ Ks. Arcybiskupie!

$\mathrm{Z}$ powodu ślubu mego syna nie mogłem dotąd zająć się skorygowaniem tekstu mej rozprawki o Teresie Neumann z uwzględnieniem życzeń Ekscelencji, obszernie wyłożonych w liście z 29 grudnia.

Gotów jestem skreślić to wszystko, co nie jest istotne, np. rozważanie nad paradoksami w nauce. Na co jednakże nie mógłbym się zgodzić? Otóż, nie mogę napisać

145 Właściwie: Radlo Peter - dr medycyny, autor m.in. pracy: Trug oder Wahrheit? Neues über Konnersreuth, Karlsruhe 1938.

${ }^{146}$ Niem.: replika dr. Deutscha jest wprost znakomita.

f-f Fragment pisany ręką abp. J. Teodorowicza.

a Tekst pisany czarnym atramentem na czterech stronicach papieru formatu A4. W lewym górnym rogu karty tytułowej firmowy nadruk; „Puszczykowo Stare k/Poznania, tel. 26”. 
w konkluzji tak, jak Ekscelencja pragnie, że, mianowicie, „T[eresa] N[eumann] nie jadła i nie piła przez przeciąg czasu, który w sferze eksperymentalnej kładzie kres życiu ludzkiemu; górnicy zasypani wytrzymują bez jedzenia i picia do 8-iu dni, burmistrz z Viterbo etc...".

Przeciwko takiemu sformułowaniu mam następujące zastrzeżenia: analogii między $\mathrm{T}$ [eresą] N[eumann] a górnikiem nie można przeprowadzać. Człowiek zasypany, nie mający wyjścia, skazany na śmierć głodową ma taki kompleks psychiczny, który przez swe działanie depresyjne osłabia wszelkie siły ustroju i jego odporność. Jeżeli górnik w takich warunkach wytrzymuje $8 \mathrm{dni}$, to myślę, że zwykły człowiek bez takiego straszliwego wstrząsu psychicznego wytrzyma 2 razy dłużej, co nawet widać na przykładzie owego burmistrza z Viterbo, który o 3 dni dłużej nie jadł i nie pił niż Teresa, a był w okropnym stanie psychicznym. Słowem - okres badania T[eresy] N[eumann] jest zbyt krótki, by móc przewidzieć, że zwykły człowiek tego by nie wytrzymał.

Drugie. „Najwyższe zaburzenia w organizmie, kt[óre] występują już po kilku dniach głodówki w organizmie ludzkim, nie istniały wcale u T[eresy] N[eumann]" - pisze Ekscelencja. Otóż, po kilku dniach głodu nie ma żadnych „najwyższych zaburzeń”, nawet po 14, a także po 30. Ustrój b[ardzo] celowo gospodaruje i tylko brak węglowodanów (=glikogenu) powoduje złe spalanie tłuszczów oraz zakwaszenie krwi i osoczy. Co jest u T[eresy] N[eumann] paradoksem, że ona odwrotnie niż wszyscy, na początku okresu badań nie spala dokładnie swych tłuszczów, skąd aceton etc., a pod koniec tego okresu właśnie je spala! Zatem badanie wydalania z niej ciał acetonowych wykazuje także zadawanie się, jak gdyby T[eresa] N[eumann] właśnie jakąś drogą wprowadzała do ustroju swego węglowodany, czemu przeczy jedynie dozór zorganizowany. Dlatego to nazywam to $^{\mathrm{b}}$ zjawisko paradoksem, wierząc $\mathrm{w}$ istnienie dozoru, a nie oszustwem jak Deutsch, który wietrzy wszędzie podstęp.

Wreszcie, T[eresa] N[eumann] przed obserwacją podobno wcale nie jadła i nie piła, więc mamy osobnika w okresie głodu i pragnienia poprzedzającego "Überwachung”. Takie przypadki nie były dotąd obserwowane. Stwierdzenie, że paradoksalne zachowanie się wagi, czyli w makrokarmie całości ustroju znajduje swe odbicie w mikrokarmie niektórych zbadanych procesów przemiany, uważam z mego punktu widzenia za rzecz najbardziej ciekawą.

Czy mogę powiedzieć, że skoro T[eresa] N[eumann] tak świetnie przebyła okres 14[dni]owej obserwacji to jest to dowodem, że w ogóle może nie jeść i nie pić? Tego nie mogę powiedzieć. Okres badania winien być stanowczo dłuższy, aby móc rzec o możliwości życia bez przyjmowania płynów, jakkolwiek 14-dniowy okres T[eresy] N[eumann] jest już wyczynem niezwykłym.

Nie mógłbym się z Ekscelencją zgodzić, iż „policyjne wykazanie” zachowania wagi wystarcza i nawet zastąpi wszelkie inne badania kliniczne i kontrolne. One są konieczne. Bo zawsze można powziąć podejrzenie, że przy ważeniu zachodzą jakieś niedokładności, na które może wpływać człowiek ważony, gdy np. zbadanie krwi na zawartość

b Wyraz powtórzony. 
mocznika jest poza możliwością oddziaływania na wynik ten [... $]^{c}$. Że ojciec T[eresy] $\mathrm{N}$ [eumann] nie chce się na to zgodzić - to oczywiście nic mnie nie wzrusza. Wolno jemu tego nie chcieć, ale wolno mnie tego żądać. Zresztą, niezależnie od mego stanowiska, KAP ${ }^{147} 19$ XII b.r. podał do wiadomości oficjalny biuletyn Ordynariatu biskupiego w Ratyzbonie. Między innymi piszą tam: „Wątpliwościom i sporom może jedynie położyć kres nowa obserwacja lekarska, ponieważ badania sprzed lat 10-ciu mogły jedynie określić ówczesny stan. Nie posiadają one znaczenia jeśli idzie o następne lata”.

Podobne stanowisko zająłem w mojej rozprawce, w której ograniczyłem się jedynie do krótkiej wnikliwej analizy raportu prof. Ewalda i wydobyłem na wierzch wnioski, których niemieccy koledzy nie zdołali ujrzeć. Dodam, że rozprawkę tę dałem do przeczytania prof. Juraszowi ${ }^{148},[\ldots]^{\mathrm{d}}$ (fizjolog), Błachowskiemu (prof. psychologii). Z wyjątkiem ostatniego, którego nie $[\ldots]^{\mathrm{e}}$ jeszcze, lekarze wraz z $[\ldots]^{\mathrm{f}}$ twierdzą, że nic innego na podstawie obserwacji Ewalda pisać niepodobna. Jurasz, kt[óry] T[eresę] N[eumann] widział, prosił o określenie pewnych miejsc i ograniczenie się do samej analizy.

W tych warunkach, idąc również za głosem wybitnych mych kolegów, nie mogę rzeczy inaczej ująć. Zrobiłem, co mogłem. Ale Ekscelencja z całym spokojem i bez żadnego żalu z mej strony może rzecz całą wrzucić do kosza. Tekst poprawię według życzeń Ekscelencji tych wszakże, które są dla mnie do przyjęcia. Również godzę się, aby moje „parere”149 było umieszczone w polemicznej rozprawie D[okto]ra Radło w części II-iej. Wobec jednak stwierdzenia biskupstwa w Ratyzbonie oraz „życzenia całego episkopatu bawarskiego, a także świętego officjum" (KAP), by Teresa N[eumann] zgodziła się na ponowną obserwację - nie mogę jako lekarz i katolik temu życzeniu się oprzeć, a tylko proponuję łagodne metody, którym należałoby T[eresę] N[eumann] poddać. Opór [... $]^{\mathrm{g}}$ Neumanna jest zrozumiały może, ale w takim razie niepodobna orzekać ostatecznie o tej całej sprawie.

Co do ujęcia sprawy przez prof. Halbana, który sformułował podany przez Ekscelencję aforyzm, to nie mógłbym się nań zgodzić. Co innego istnienie czegoś co nazywamy stanem, a co innego „policyjna” obserwacja wahań wagi. Za dużo jest stopni dowolności w obu wypadkach, aby móc wyciągnąć ten sam wniosek dla określenia nadprzyrodzonego zjawiska.

Przepraszam za zbyt długi list i proszę przyjąć wyrazy najgłębszej czci i synowskiego oddania oraz życzenia pomyślnego N[wego] Roku

St[efan] Dąbrowski

\footnotetext{
c Wyraz nieczytelny.

147 Katolicka Agencja Prasowa - instytucja kościelna funkcjonująca w II Rzeczypospolitej.

148 Jurasz Antoni (1882-1961), dr medycyny, 1919-1920 prof. tytularny na Uniwersytecie Johanna Wolfganga Goethego we Frankfurcie nad Menem, od 1920 związany z Uniwersytetem Poznańskim: kierownik Katedry Chirurgii, 1925-1927 dziekan Wydziału Lekarskiego Uniwersytetu Poznańskiego, w roku akad. 1930/31 prorektor uczelni, 1939-1940 przebywał we Francji, 1940-1947 mieszkał w Anglii, 1947-1961 pracował w USA. Jurasz Antoni, w: WSB, red. A. Gąsiorowski, J. Topolski, Warszawa-Poznań 1981, s. 303-304.

d Wyraz nieczytelny.

e Wyraz nieczytelny.

f Wyraz nieczytelny.

149 Łac.: opinia.

g Wyraz nieczytelny.
} 


\section{Dokument 45}

Oryg.: AFKDOPW, teczka 139: Spuścizna abp. Józefa Teodorowicza, sygn. 1319/365 [5], List prof. Stefana Dąbrowskiego do abp. Józefa Teodorowicza, Puszczykowo Stare 9 I 1938 r.

Najprzewielebniejszy Ks. Arcybiskupie!

Puszczykowo Stare, dnia $9^{\text {a- }}$ grudnia $^{-a} 1938$

W myśl ostatniego listu Ekscelencji przesłałem tekst mej rozprawki o T[eresie] Neumann $^{150}$. Wysyłam całość, jak tylko fotografie wykresów będą gotowe. Zatem w środę Ekscelencja całą rzecz otrzyma. Wobec ostatniego komunikatu Episkopatu Bawarskiego, którego żądanie co do nowej bardziej naukowej i dłuższej obserwacji T[eresy] N[eumann] zostało poparte przez Święte Officium, uważam, że niepodobna upierać się przy zdaniu, że 14-dniowa obserwacja jest wystarczająca i najzupełniej decydująca. W istocie jest ona zbyt krótka i niezupełna, ale nawet taka rzuca niezmiernie ciekawe światło na procesy fizjologiczne, które w zwykłym trybie rozważań nie znajdują wytłumaczenia.

Następnie ośmielam się zwrócić uwagę Ekscelencji, że lepiej by było, aby część polemiczną o treści teologicznej czy psychologicznej nie podpisywał medyk, w danym wypadku Dr Radło. Lepiej by było, gdyby tę część napisał np. Ks. Bogdanowicz albo inny kapłan. Wtedy ksiądz z profesorem byłby odpowiedniejszym zespołem niż lekarz praktyk, który pisze o mistycyźmie, a prof[esor] chemii fizjologicznej o metabolizmie. Wydaje mi się, że tego rodzaju para jest podobna do tego, co mówią pospolicie, że „nie potrzeba dwóch grzybów w barszczu". Proszę najuprzejmiej myśl tę rozważyć.

Łączę przy tej sposobności wyrazy czci i synowskiego oddania

Stefan Dąbrowski

\section{Dokument 46}

Oryg.: APANP, sygn. P III - 116, teczka 86, List abp. Józefa Teodorowicza do prof. Stefana Dąbrowskiego, Lwów 10 I 1938 r.

Kochany ${ }^{a}$ Panie Profesorze!

Lwów, dnia 10 I 1938 r.

Dziękuję Panu Profesorowi za list ostatni i mam wszelką nadzieję, że dojdziemy do wspólnego porozumienia. Jeszcze raz powtarzam moją opinię wyrażoną w liście poprzednim, że uważam pracę Pańską za świetną i argumentacje przeciw osądzeniu Deutscha za rozstrzygające, a to jest przecież najważniejsze. I właśnie dlatego pisałem Panu Profesorowi, że zgadzam się na całą pracę aż do str. 13.

a-a Wyraz przekreślony ołówkiem i poprawiony na: „stycznia”.

b Tekst pisany czarnym atramentem na 1,5 stronicy papieru formatu A4. W lewym górnym rogu podłużna pieczęć: „Puszczykowo Stare k/Poznania, tel. 26”.

150 AFKDOPW, teczka: Spuścizna abp. Józefa Teodorowicza, bsygn., S. Dąbrowski, Paradoxer metabolismus im Falle der Therese Neumann von Konnersreuth, bmr, ss. 18, mps.

a Tekst pisany maszynowo $\mathrm{z}$ wyjątkiem fragmentu zaznaczonego na 5 stronicach papieru formatu A4. 
O ile do strony 13 głównie Pan Profesor zajmował się krytyką poprzedniej obserwacji, to od str. 13 Pan Profesor przechodzi do zupełnie innego tematu, mianowicie przedstawia Pan Profesor jak by miała wyglądać obserwacja przyszła. Dlatego sądziłem, że ograniczenie się do głównego tematu przez Pana Profesora jest w tym wypadku już choćby z tego względu wskazane, ażeby pozostawić wolność w działaniu tym doktorom, którym ewentualnie obserwacja Teresy Neumann będzie zlecona. W tej bowiem kwestii są zdania lekarzy ogromnie podzielone i rozstrzelone. Jest w tym istny chaos opinii. Tak np. Pan Profesor pisze, że dwutygodniowa obserwacja nie wystarcza. Są inni lekarze, którzy tak samo sądzą jak Pan Profesor, ale są i tacy i to pośród powag naukowych, których zapatrywania są wręcz inne. Wzmiankę o tym Pan Profesor czytał z pewnością w sprawozdaniu Dr. Hohn'a.

Ale pomijam to sprawozdanie. Przed otrzymaniem listu Pana Profesora, rozmawiał o tym ze mną przyjaciel Dr. Koskowskiego Docent Kmietowicz. Otóż on twierdzi, że dwa tygodnie obserwacji jest za dużo, że wystarczy zupełnie $10 \mathrm{dni}$, a to z tego powodu, że przy niejedzeniu i niepiciu występują w normalnym stanie takie zmiany w organizmie, że wystarczą one zupełnie do powzięcia sądu, jaki jest charakter głodu.

Tu tylko podaję próbki różnych poglądów nie wchodząc w meritum rzeczy. A już przeważa zdanie - co do mnie nie spotkałem się nawet $\mathrm{z}$ innym zdaniem pośród lekarzy - że obserwacja potwierdzając niejedzenie i niepicie przy równoczesnym zachowaniu wagi jest rozstrzygającą $\mathrm{w}$ tym problemie bez udawania się do żadnych klinicznych zabiegów. Te wprawdzie mogą być użyte ale z wyraźnym zastrzeżeniem, że służą tylko interesowi i ciekawości wiedzy, ale nie są istotne tam, gdzie przez długą obserwację zostało stwierdzone niejedzenie i niepicie. Nie chcę tu wchodzić jako laik w żadne dyskusje naukowe, ale nie wątpię, że Pan Profesor zechce przystać na to rozróżnienie, które ogranicza się li tylko do jednego wiersza na tych 14 stronach. Prosiłbym, by Pan Profesor zrezygnował z drugiego tematu jakim się zajął, to jest z przedstawienia projektu dla przyszłej obserwacji. Bardzo gorąco Pana Profesora o to proszę, by chciał się do mej prośby przychylić, która pozwoli Panu Profesorowi zachować dla siebie opinie lekarskie jakiekolwiek by one były, a równocześnie nie utrudniać sytuacji. Nadzieję moją opieram na tym, iż Pan Profesor wprost się zwraca do Biskupów niemieckich, a teraz powołuje się na stanowisko Biskupa Regensburskiego.

Otóż ja sam niczego innego nie chcę, jak tylko tego, by Pan Profesor na tym stanowisku stanął, jakie zajął Biskup Regensburski, względnie Biskupi niemieccy. Już poprzednio w „Lexikon für Theologie u[nd] Kirche” Biskup Regensburski pisząc o Konnersreuth wyraźnie zaznaczył, iż wyklucza oszustwo. Obecne zaś oświadczenie Biskupa regensburskiego, które nawiasem mówiąc nastąpiło wskutek groźby rządu niemieckiego iż sam zajmie się obserwacją Teresy Neumann, jest tylko potwierdzeniem poprzedniego stanowiska. Albowiem obecnie nie dlatego Biskup chce zarządzić nową obserwację, jakoby pierwsza była niedostateczną, ale czyni to dlatego, że od pierwszej upłynęło 10 lat. Pierwsza tedy obserwacja jest uznana pośrednio za wystarczającą. Niezależnie od tego stanowiska, z ogłoszonego przez Dr. Deutscha świeżo pisma w jednym z katolickich organów wiedeńskich wynika, iż on sam nie żąda dla swej obserwacji jakichkolwiek 
klinicznych zabiegów. Ale pójdę jeszcze dalej: cały szereg czy stygmatyzowanych osób, czy innych przeprowadzonych przez Kościół, a służących za podstawę przy procesach kanonizacyjnych ograniczał się li tylko wyłącznie do obserwacji technicznej, do badań detektywistycznych.

Pan Profesor rozumie więc łatwo, iż podanie w wątpliwość jedynego środka badań jakim się posługuje Kościół i przedstawienie go jako niedostatecznego, o ile nie jest połączony $\mathrm{z}$ badaniem klinicznym, godzi wprost $\mathrm{w}$ wyniki wszelkich obserwacji kościelnych zdobytych wiekową praktyką. Zdaniem Kościoła, schodzi się zupełnie zdanie fachowe lekarza. Dałem np. pracę Pana Profesora do przeczytania dwom lekarzom, z których jeden jest znakomitym pisarzem naukowym. Oni obydwaj byli z całym uznaniem dla wartości naukowych pracy Pana Profesora, ale obydwaj orzekli - jeden o drugim nic nie wiedząc - że należy się wstrzymać na stronie 13 pracy Pańskiej i zrobić wyraźne rozróżnienie między badaniami detektywistycznymi a zabiegami klinicznymi. Ten właśnie pisarz mi powiedział: „Jeżeli pod drzwiami postawi się żołnierza z bagnetem i jeżeli ten żołnierz w zmienianej warcie dzień i noc nie da nikomu dostępu przez czas dłuższy, to mi nie potrzeba niczego by stwierdzić, że przez cały ten czas $\mathrm{X}$ nic nie jadł i nic nie pił, i nie stracił na wadze, co w normalnych warunkach jest nie do osiągnięcia”.

Dlatego jeszcze raz przedstawiam Panu Profesorowi motywy podyktowane już nie tylko samą sprawą Konnersreuth, ale szerzej pojętymi interesami Kościoła i mam pełną nadzieję, że Pan Profesor zechce je uwzględnić.

Przy tej sposobności proszę o zwrot podanych na spisie załączonym przez Sekretariat prac wraz z pracą Dr. Hohn'a.

Gdyby Pan Profesor jeszcze miał jakąś trudność w moim projekcie, to wtedy prosiłbym o to, ażeby Pan Profesor zechciał przyjechać do Lwowa pod warunkiem, że się zgodzi na zwrot opłaty biletu kolejowego i wtedy byśmy ostatecznie sprawę ułożyli.

Nie potrzebuję dodawać, jakbym się bardzo ucieszył, gdybym się mógł z Panem Profesorem zobaczyć.

${ }^{\mathrm{b}-Z}$ wyrazami oddanymi mej głębokiej czci dla Państwa

† Teodorowicz ${ }^{-b}$

Wielmożny Pan Profesor

Dr Stefan Dąbrowski

Puszczykowo k/Poznania

b-b Nota ręką abp. J. Teodorowicza. 


\section{Dokument 47}

Oryg.: APANP, sygn. P III - 116, teczka 86, List abp. Józefa Teodorowicza do prof. Stefana Dąbrowskiego, Lwów 12 I 1938 r.

Kochany ${ }^{a}$ Panie Profesorze!

Lwów, dnia 12 I 1938 r.

Bardzo dziękuję za wczorajszy list. Bardzo ucieszyłem się nim, gdyż widzę, że jest tylko jakieś nieporozumienie między nami. Panu Profesorowi widocznie się wydaje, że ja mam jakieś zastrzeżenia przeciw temu, jakoby dłuższa obserwacja nad 2 tygodnie była wskazaną i że nie dzielę stanowiska Biskupów względnie Biskupa bawarskiego co do ponownej obserwacji.

Otóż przytaczam tu w załączeniu Panu Profesorowi dwa miejsca z mojej książkib, które - ufam - usuną wszelkie pod tym względem wątpliwości.

Na czym mi zależy, to wyjaśniłem we wczorajszym liście Panu Profesorowi i mam nadzieję, że pod tym względem pogodzimy się.

Uwaga Pana Profesora co do Dr. Radły jest słuszna i już uwzględniłem po części ten szkopuł. Przesyłam Panu Profesorowi kartę tytułową pracy przeciw Deutschowic.

Pewnie Pan Profesor wie, iż jest jutro polowanie u pp. Dubanowiczów ${ }^{151}$ i właśnie dziś w południe ma być u mnie Stroński. Wczoraj był u mnie Książę Czartoryski, czyta[łe]m mu ustęp z listu Pańskiego i utwierdziłem go w tym, by śmielej niż dotąd postępować.

Łączę przy tej sposobności dla Przezacnych Państwa bardzo serdeczne wyrazy mej czci głębokiej

† Teodorowicz

\section{Dokument 48}

Oryg.: AFKDOPW, teczka 139: Spuścizna abp. Józefa Teodorowicza, sygn. 1299/365 [5], List prof. Stefana Dąbrowskiego do abp. Józefa Teodorowicza, Poznań 13 I 1938 r.

Poznań, dnia 13 I 1938 r.

Najprzewielebniejszy ${ }^{a}$ Księże Arcybiskupie.

Wczoraj otrzymałem list Ekscelencji, na który zaraz odpowiadam, by równocześnie odpowiedź tę przesłać z drugą redakcją mej rozprawki o Teresie N[eumann].

Wydaje mi się, że nieporozumienie między nami polega na tym, iż Ekscelencja przeciwstawia metody „detektywistyczne” metodom „klinicznym”. W istocie i metody kliniczne są w pewnym sensie detektywistycznymi. Najbardziej cenne w pracy prof. Ewalda

a Tekst pisany na jednej stronicy papieru formatu A4 maszynowo z wyjątkiem autografu autora.

b Brak załącznika.

Tu załącznik.

${ }^{151}$ Maria Magdalena i Edward Dubanowiczowie posiadali swój matątek Huta Szklana w pow. Brody, woj. Tarnopol.

a Tekst pisany maszynowo na 3,5 stronicach papieru formatu A4. Autograf autora pisma czarnym atramentem. 
są właśnie owe metody kliniczne, niestety zbyt skąpe i mało fachowe z punktu widzenia przemiany materii, jakkolwiek Teresa N[eumann] nie znajdywała się w klinice.

Dopiero teraz czytam książkę Ekscelencji i np. podzielam pogląd, wypowiedziany w rozdziale „Klinik oder nicht” (s. 137) przeciw badaniu T[eresy] N[eumann] w tzw. „neutralnej klinice”. Czy wszelako z tego wynika, że nie należy przemiany materii i energii badać nowoczesnymi sposobami, o których piszę? Bynajmniej. Bowiem żadna klinika nie jest przygotowana do tego rodzaju badań, które będąc bez zarzutu pod względem ścisłości, równocześnie zapewniają badanej osobie spokojny sposób życia w izolowanej od świata kamerze. Dlatego tylko, mianowicie dla braku odpowiedniej aparatury jestem przeciwny ponownemu badaniu klinicznemu.

Jeżeli lekarz i zarazem wybitny pisarz powiedział Ekscelencji, że „wystarczy pod drzwiami postawić żołnierza z bagnetem", który nikogo do badanej nie dopuści i tym samym stwierdzi, że owa ofiara ciekawości ludzkiej nie przyjmuje pokarmów i napojów i że, co więcej, to stwierdzenie jest wystarczającym dowodem pełnej abstynencji, to proszę temu nieznanemu mi koledze powiedzieć, by ten swój pogląd ogłosił pod własnym nazwiskiem w czasopiśmie naukowym. Na pewno tego nie uczyni.

Jeżeli p[an] doc. Kmietowicz twierdzi, że „dwa tygodnie obserwacji jest za dużo, że wystarczy zupełnie $10 \mathrm{dni}$, aby z całą pewnością ustalić fakt, jaki jest charakter głodu", to śmiem zapytać kol[egę] Docenta, jakimi to metodami ten właśnie specyficzny charakter abstynencji u T[eresy] N[eumann] będzie ustalony? Czy detektywistycznymi, policyjnymi, czy też z naukowymi, a w takim razie jakimi? Proszę bardzo o program.

Takie poglądy, śmiem twierdzić, są sugerowane Ekscelencji w ciszy przemiłego salonu pałacu Arcybiskupiego we Lwowie. Lecz kto z tych panów kolegów za wygłaszane poglądy poniesie osobiście odpowiedzialność naukową na forum europejskim? Jeżeli są gotowi tę odpowiedzialność wziąć, to niechaj rzecz całą opracują do druku.

Nie jest dla mnie niespodzianką, o czym Ekscelencja pisał ostatnio, że obecne orzeczenie Biskupa Regensburskiego nastąpiło wskutek groźby rządu hitlerowskiego, iż sam się zajmie obserwacją Teresy N[eumann]. Od dawna przewidywałem, że narodowo-socjalistyczna nauka zajmie się Teresą N[eumann] ku jej nieszczęściu. Dlatego rozumiem opór jej ojca. Czy nie lepiej zresztą wobec tej groźby pozostawić rzecz całą w spokoju, o Teresie N[eumann] nie pisać, zamiast podniecać ciekawość wrogów Kościoła i szerszej publiczności, której niepodobna zaspokoić za pomocą zrozumiałych i ścisłych kryteriów naukowych?

W końcu nie mogę się zgodzić na pogląd Ekscelencji, że jeżeli proponuję wszechstronnie zbadać paradoksalny metabolizm u Teresy N[eumann] w sposób nowoczesny i nie ograniczam się do metod dotąd przez Kościół używanych przy procesach kanonizacyjnych, to przez to samo "godzę wprost w wyniki wszelkich obserwacji kościelnych, zdobytych wiekową praktyką". Przecież komitet lekarski w Lourdes posługuje się wszelkimi metodami naukowymi, aby stwierdzić, że dana choroba nie mogła być uleczona sposobami zwykłymi. Czy przez to samo ów komitet godzi w Kościół i przeszkadza w stwierdzeniu cudownego uleczenia? Zdaje mi się, że wprost przeciwnie.

Aby streścić mą odpowiedź na ostatni list Ekscelencji dodaję jeszcze tylko to: nieporozumienie między nami w sprawie mojego opracowania somatycznej strony abstynencji 
Teresy N[eumann] wynikło z tego, że nie zrozumiałem dokładnie dezyderatów Ekscelencji mimo mej najlepszej woli. $Z$ powodu moich obecnych zajęć nie mogę myśleć na razie o przyjeździe do Lwowa dla rozmowy z Ekscelencją, ani też o pisaniu nowej rzeczy o Teresie N[eumann], przeto nie jestem w stanie, niestety, w tej sprawie nic już więcej zrobić. Moje opracowanie stanowi pewną organiczną całość, z której niepodobna nic już obciąć, nie psując całego toku moich wywodów.

Proszę przyjąć wyrazy najgłębszej czci i synowskiego oddania.

${ }^{\mathrm{b}-S t e f a n}$ Dąbrowski ${ }^{-\mathrm{b}}$

Jego Ekscelencja Ksiądz Arcybiskup

Dr Józef Teodorowicz

we Lwowie

\section{Dokument 49}

Oryg.: AFKDOPW, teczka 139: Spuścizna abp. Józefa Teodorowicza, sygn. 1298/365 [5], List prof. Stefana Dąbrowskiego do abp. Józefa Teodorowicza, Poznań 14 I 1938 r.

Poznań, dnia 14 stycznia 1938

Najprzewielebniejszy ${ }^{\mathrm{a}}$ Ks. Arcybiskupie!

List odebrałem i odpisuję tylko w paru słowach, które najłaskawiej proszę wziąć pod uwagę. Jeżeliby Ks. Arcybiskup przyjął mój ostateczny tekst i decydował się na jego przekład na język francuski, to prosiłbym najuprzejmiej o przysłanie mi pierwszej korekty, którą chciałbym, aby ją przeczytał prof. Jurasz. Jeżeli praca moja nie będzie odpowiadała interesom Ekscelencji, to prosiłbym o zwrot tekstów. Żądane książki i broszurę Ekscelencji, które są u mnie, w tych dniach odeszlę

Łączę wyrazy najgłębszej czci i synowskiego oddania

St[efan] Dąbrowski

\section{Dokument 50}

Kopia: AFKDOPW, teczka: 128, Spuścizna abp. Józefa Teodorowicza, sygn. 1294/365 [5], Kopia listu abp. Józefa Teodorowicza do prof. Stefana Dąbrowskiego, Lwów 25 I 1938 r.

Kochany ${ }^{a}$ Panie Profesorze,

Lwów, dnia 25 stycznia 1938 r.

b-b Tekst sporządzony czarnym atramentem.

a Tekst pisany czarnym atramentem na jednej stronicy papieru formatu A4. W lewym górnym rogu nadruk firmowy: „Dziekan Wydziału Lekarskiego Uniwersytetu Poznańskiego”.

b Forma zgodna z oryginałem.

a Tekst pisany maszynowo na pięciu stronicach papieru formatu A4. Brak autografu autora. W lewym górnym rogu karty tytułowej nota czarnym atramentem: „Do Prof. Dąbrowskiego. List próbny Nr 1 . Nie odszedł". 
Wysłałem telegram ${ }^{\mathrm{b}}$ Panu Profesorowi z podziękowaniem i oświadczeniem, że pomieszczę artykuł Pana Profesora w książce. Oparłem się na tym, że Pan Profesor po przeczytaniu mojego rozdziału „Klinik oder nicht?”152 oświadczył, iż podziela mój pogląd. To mnie uprawnia do zaniesienia prośby do Pana Profesora, ażeby sprzeczne z tym moim poglądem zdania w swym artykule, mianowicie od str. [... $]^{c}$ opuścił. I jeżeli się oświadczyłem w telegramie, że przyjmę pracę Pana Profesora, to uczyniłem to w tej nadziei, że Pan Profesor mej prośbie zadośćuczyni, uważając dziś już postawienie jasne mej prośby za logiczne następstwo stanowisko Pana Profesora. Bo chyba nie może dłużej podtrzymywać Pan Profesor tezy, iż „Ewald ma rację”, a równocześnie być w zgodzie $\mathrm{z}$ moją zasadniczą opinią.

Powie mi Kochany Pan Profesor, że „nie rozumiał dotąd mych dezyderiów mimo swej najlepszej woli”. Z pewnością tak było i dlatego bardzo żałuję, że Pan Profesor jednak wcześniej nie zapoznał się z moimi dezyderiami i nie przeczytał ustępu odnośnego mojej książki.

Być może, że wtedy Pan Profesor byłby mi powiedział, że nie może przystać na moje stanowisko i nie może pracy tej się podjąć - to zupełnie rozumiem i byłbym się oglądał za innym rodzajem wyjścia. Najfatalniej się stało, że Pan Profesor dopiero teraz przeczytał ustęp z mej książki o głodzie, ale całe zadowolenie moje obecne tkwi w tym, że Pan Profesor w zasadzie moje zapatrywania podziela i dlatego pozwala mi na wyrażenie nadziei, że Pan Profesor ostatecznie zadośćuczyni mej gorącej prośbie.

A teraz przystępuję do rzeczy zasadniczej. Nie mogę się absolutnie zgodzić na jakiekolwiek porównanie i zestawienie Komitetu z Lourdes z tą sprawą. Argument Pana Profesora - proszę mi darować - jest taki sam, jak argument Deutscha, który właśnie zwalczam w obecnej mej pracy. Zachodzi między Panem Profesorem a Deutschem tylko ta różnica, że Dr Deutsch stosuje tu argument do choroby Teresy Neumann, a Pan Profesor do jej głodu. Chyba co innego jest głód, a co innego choroba? Ponadto Kościół nie bierze żadnej odpowiedzialności za orzeczenia Komisji lekarskiej w Lourdes, natomiast bierze pełną odpowiedzialność za stwierdzenie cudownego faktu głodu w bullach kanonizacyjnych. Kościół nic nie ma przeciw temu, ażeby badać środkami nowoczesnymi stan choroby, ale z drugiej strony Kościół absolutnie przeciw temu zastrzec się musi, jakoby tylko to miało być uznane za cud, co jest stwierdzone nowoczesnymi badaniami. Nie można identyfikować jednego z drugim, nie można z tego, iż Kościół uważa za pożądane używanie środków nowoczesnych przy badaniu chorób wyciągać wniosku, iż w braku takich środków cud jest niestwierdzalny.

I proszę mi darować, ale w tym punkcie Pan Profesor się myli zasadniczo. Gdyby taka zasada coś znaczyła, to co 50 lat Kościół musiałby przekreślać swoje bulle kanonizacyjne $\mathrm{w}$ miarę jak postęp w medycynie uważałby za przestarzałe metody badań uznane poprzednio za wystarczające.

b Brak owego dokumentu.

${ }^{152}$ Niem.: klinika albo nic.

c Brak tekstu. 
Wykazałem to w mej rozprawie z Dr. Deutschem na przykładzie konkretnym uzdrowienia p[ani] Kopeckiej ${ }^{153}$. Uzdrowienie to uznane zostało przez Kongregację za cud istotny, mimo to, że jej choroba nie została stwierdzona żadnymi nowoczesnymi środkami i mimo, że lekarz ordynujący umarł, nie zostawiwszy żadnych odnośnych dokumentów.

Ale i Komisja w Lourdes nie jest bynajmniej tak hiperkrytyczna, jak się zdaje. W mojej rozprawie z Deutschem przytaczam na to przykłady, jak doktorzy tej Komisji wprost $\mathrm{z}$ ironią odnoszą się do tych, co za warunek stwierdzenia cudu uważają aplikatę nowoczesnych środków jak Roentgen etc. Dlatego jeszcze raz z naciskiem powtarzam, że nic nie mam przeciw temu, by także badać stan głodu sposobami nowoczesnymi, ale nigdy się nie można zgodzić na to, by uzależnić tylko od tych sposobów stwierdzenie nadprzyrodzonego charakteru głodu.

Kto raz stanie na takim stanowisku, kto uważa jako sine qua non ${ }^{154}$ badania kliniczne, a za niewystarczające badanie obserwacyjne, ten popada w hiperkrytycyzm i ten godzi we wszystkie te wypadki głodu, które uznał Kościół za cudowne i które były stwierdzone tylko przez obserwację bez klinicznych badań.

Nie mówię już o tym, że Pan Profesor po przeczytaniu mojego rozdziału, aczkolwiek tak spóźnionym, uważa sam, że umieszczenie ustępu końcowego godzi w moje stanowisko zarówno w książce, jak i w obecnej mej polemice z Deutschem. Ja to czułem od pierwszej chwili, ale nie chciałem przykrości czynić Panu Profesorowi jasnym wypowiedzeniem tego, iż niepodobna jest żądać ode mnie, ażeby zwalczając Deutscha i Ewalda przytaczał na dowód pracę, która wprawdzie częściowo występuje przeciw Deutschowi, ale $w$ istocie rzeczy uważa obserwację pierwszą tak jak Deutsch za zupełnie niedostateczną. Teraz już muszę Panu Profesorowi to otwarcie powiedzieć w chwili, gdy mam to przeświadczenie, że Pan Profesor uwzględniwszy przynajmniej w głównych zarysach moje stanowisko, tych konsekwencji wyciągać nie będzie. Zresztą te konsekwencje są dziś sprzeczne z tym, co Pan Profesor wyraża w swej pracy godząc się na to, że kliniczne zabiegi mają na celu zadośćuczynienie zainteresowaniom naukowym, ale nie są czymś istotnym w badaniu.

Nie w „moim miłym salonie”, ale w sali klinicznej trzej lekarze czytali rozprawę Pana Profesora, którą dałem jednemu z nich do przejrzenia ze względu na zwroty językowe niemieckie. Nie wiedziałem nic o tym, że lekarz ów zaprosi do czytania swoich kolegów; jeden $\mathrm{z}$ nich objechał wszystkie kliniki, w nich praktykował $\mathrm{i}$ jest znakomicie z problemem obeznany. Otóż wszyscy trzej stwierdzili zgodnie, iż praca Pana Profesora posiada znakomite wartości naukowe, ale stwierdzili zarazem sprzeczności w poglądach Pana Profesora (te podaję w zestawieniu na osobnej kartce) ${ }^{\mathrm{d}}$ i orzekli, iż ostatni ustęp jest mętny i obniża wartość całej pracy. Powiedział mi zarazem ów lekarz, że w ogóle w medycynie uważa się dziś nie tylko w sprawie głodu, jak i innych nieraz badaniach, badanie detektywistyczne nieraz za ważniejsze od badań klinicznych. Te są niejednokrotnie dopiero w powijakach, kiedy tymczasem badania detektywistyczne nie zawodzą nigdy, gdy są dobrze przeprowadzone.

\footnotetext{
${ }^{153}$ Osoba niezidentyfikowana.

154 Łac.: konieczne.

d Brak tegoż materiału.
} 
Nie wchodzę w to, czy ten, czy ci lekarze mieli słuszność, ale to jest dla mnie wymownym przykładem, że nie może być mowy o przeprowadzeniu obserwacji, skoro jeden lekarz przeczy temu, co drugi powie. To schodzi po prostu ad absurdum155, dlatego prosiłem Pana Profesora, by się ograniczył w swej pracy do zakresu, o jaki był proszony, t.j. by wykazać, że nie ma powodu pomawiania Teresy Neumann o oszustwo. Wszelkie wkraczanie w dziedzinę przyszłej obserwacji nie należy do tematu, wikła rzecz i może mieć pozory nielojalności przez przesądzenie kwestii wobec lekarzy, którym będzie badanie zlecone.

Muszę jeszcze przy tej sposobności sprostować pewien szczegół, który niedokładnie podałem. Profesor Kmietowicz był u mnie nie w związku z pracą Pańską, z którą zupełnie się zgadza, lecz w związku z projektem czeskiego doktora co do ponownej obserwacji Teresy Neumann.

Ponieważ miałem temu ostatniemu dać odpowiedź, a Prof. Koskowskiego nie było, więc pytałem o to p[ana] Docenta Kmietowicza, oczywiście, że on mówił o zabiegach klinicznych, ale też w przeciwieństwie do innych domagał się tylko 10 dni obserwacji. Tyle dla wyjaśnienia tego szczegółu.

Dziękując Panu Profesorowi za łaskawe względy dla mego „salonu”, mogę zapewnić Pana Profesora, że nikt z tych, co u mnie byli nie zna Benedykta XIV ${ }^{156}$ i jego rozprawy o głodzie, która była podstawą dla moich wszystkich wniosków.

Pan Profesor daje mi radę, aby o Teresie Neumann nie pisać. Wierzę, że ta rada płynie z najlepszego serca i intencji Pana Profesora i jestem o tym przekonany, ale chyba Pan Profesor zdaje sobie z tego sprawę, że po całorocznej pracy, po umowach z nakładcami, po zaawansowanym druku jest taka rada naprawdę bardzo spóźniona. Cenię ją, jak zawsze wszystko, co od Pana Profesora pochodzi, ale contra factum non est argumentum ${ }^{157}$. Ja jednak wcale nie jestem zdania by nie pisać, albowiem uważam, że problem stygmatyzacji przeżyje zarówno mnie, jak Hitlera, jak Teresę Neumann. Ja piszę dla przyszłości.

Zbyt dobrze znam Pana Profesora i nazbyt polegam na Jego życzliwości i przyjaźni dla mnie, ażebym przypuścił, by Pan Profesor mógł wziąć mi za złe me bardzo szczere i otwarte słowa.

Przeciw Katarzynie Emmerich ${ }^{158}$ podnoszono zarzut, że jest oszustką, a pomimo tego jej kanonizacyjny proces jest w toku.

Łączę dla Pana Profesora wyrazy oddane mej głębokiej czci.

P.S. Prof. Koskowskiego niestety nie mogłem widzieć z powodu jego wyjazdu do Warszawy.

155 Łac.: do absurdu.

156 Benedykt XIV/Prospero Lorenzo Lambertini (1675-1758), włoski katolicki duchowny, w 1727 r. mianowany biskupem Ankony, w 1726 r. kreowany kardynałem, w 1731 r. objął urząd arcybiskupa Bolonii, 1740-1758 papież.

157 Łac.: wbrew faktom nie ma argumentów.

158 Emmerich/Emmerick Anna Katarzyna (1774-1824), niemiecka stygmatyczka i wizjonerka, od $1802 \mathrm{r}$. należała do Zakonu ss. Augustianek, od $1813 \mathrm{r}$. wskutek wypadku i choroby pozostawała unieruchomiona znosząc cierpienia oraz doświadczając wizji m.in. męki Chrystusa. Beatyfikowana w 2004 r. przez Jana Pawła II. J. Zbiciak, Emmerick/Emmerich, Anna Katharina, w: EK, t. 4, red. zbior., Lublin 1985, kol. 954-955 


\section{Dokument 51}

Kopia: AFKDOPW, bsygn., Spuścizna abp. Józefa Teodorowicza, Kopia listu abp. Józefa Teodorowicza do prof. Stefana Dąbrowskiego, Lwów 25 I 1938 r.

Kochany ${ }^{a}$ Panie Profesorze,

Lwów, dnia 25 stycznia $1938 \mathrm{r}$.

Wysłałem telegram ${ }^{\text {b }}$ Panu Profesorowi z podziękowaniem i oświadczeniem, że pomieszczę artykuł Pana Profesora w książce. Oparłem się na tym, że Pan Profesor po przeczytaniu mojego rozdziału „Klinik oder nicht?” oświadczył, iż podziela mój pogląd. To mnie uprawnia do zaniesienia prośby do Pana Profesora, ażeby sprzeczne z tym moim poglądem zdania w swym artykule, mianowicie od str. 13 opuścił. I jeżeli się oświadczyłem w telegramie, że przyjmę pracę Pana Profesora, to uczyniłem to w tej nadziei, że Pan Profesor mej prośbie zadośćuczyni, uważając dziś już postawienie jasne mej prośby za logiczne następstwo stanowisko Pana Profesora. Bo chyba nie może dłużej podtrzymywać Pan Profesor tezy, iż „Ewald ma rację”, a równocześnie być w zgodzie z moją zasadniczą opinią?

Powiada mi Kochany Pan Profesor, że „nie rozumiał dotąd mych dezyderiów mimo swej najlepszej woli”. Z pewnością tak było i dlatego bardzo żałuję, że Pan Profesor jednak wcześniej nie zapoznał się z moimi dezyderiami i nie przeczytał ustępu odnośnego mojej książki.

Być może, że wtedy Pan Profesor byłby mi powiedział, że nie może przystać na moje stanowisko i nie może pracy tej się podjąć - to zupełnie rozumiem i byłbym się oglądał za innym rodzajem wyjścia. Najfatalniej się stało, że Pan Profesor dopiero teraz przeczytał ustęp z mej książki o głodzie, ale całe zadowolenie moje obecne tkwi w tym, że Pan Profesor w zasadzie moje zapatrywania podziela i dlatego pozwala mi na wyrażenie nadziei, że Pan Profesor ostatecznie zadośćuczyni mej gorącej prośbie. Wnoszę to ze słów Pana Profesora: „Dopiero teraz czytam książkę Ekscelencji i np. podzielam pogląd wypowiedziany w rozdziale «Klinik oder nicht?»"

A teraz przystępuję do rzeczy zasadniczej. Nie mogę się absolutnie zgodzić na jakiekolwiek porównanie i zestawienie Komitetu z Lourdes z tą sprawą. Argument Pana Profesora - proszę mi darować - jest taki sam, jak argument Deutscha, który właśnie zwalczam w obecnej mej pracy. Zachodzi między Panem Profesorem a Deutschem tylko ta różnica, że Dr Deutsch stosuje tu argument do choroby Teresy Neumann, a Pan Profesor do jej głodu. Chyba co innego jest głód, a co innego choroba? Ponadto Kościół nie bierze żadnej odpowiedzialności za orzeczenia Komisji lekarskiej w Lourdes, natomiast bierze pełną odpowiedzialność za stwierdzenie cudownego faktu głodu w bullach kanonizacyjnych. Kościół nic nie ma przeciw temu, ażeby badać środkami nowoczesnymi stan choroby, ale z drugiej strony Kościół absolutnie przeciw temu zastrzec się musi,

a Tekst pisany maszynowo na dziewięciu stronicach papieru formatu A4. Brak autografu autora. W lewym górnym rogu karty tytułowej nota czarnym atramentem: „Do Prof. Dąbrowskiego. List próbny Nr 2. Nie odszedł".

b Brak owego dokumentu. 
jakoby tylko to miało być uznane za cud, co jest stwierdzone nowoczesnymi badaniami. Nie można identyfikować jednego z drugim, nie można z tego, iż Kościół uważa za pożądane używanie środków nowoczesnych przy badaniu chorób wyciągać wniosku, iż w braku takich środków cud jest niestwierdzalny.

I proszę mi darować, ale w tym punkcie Pan Profesor się myli zasadniczo. Gdyby taka zasada coś znaczyła, to co 50 lat Kościół musiałby przekreślać swoje bulle kanonizacyjne $\mathrm{w}$ miarę jak postęp w medycynie uważałby za przestarzałe metody badań uznane poprzednio za wystarczające.

Wykazałem to w mej rozprawie z Dr. Deutschem na przykładzie konkretnym uzdrowienia p[ani] Kopeckiej. Uzdrowienie to uznane zostało przez Kongregację za cud istotny, mimo to, że jej choroba nie została stwierdzona żadnymi nowoczesnymi środkami i mimo, że lekarz ordynujący umarł, nie zostawiwszy żadnych odnośnych dokumentów.

Ale i Komisja w Lourdes nie jest bynajmniej tak hiperkrytyczna jak się zdaje. W mojej rozprawie z Deutschem przytaczam na to przykłady, jak doktorzy tej Komisji wprost z ironią odnoszą się do tych, co za warunek stwierdzenia cudu uważają aplikatę nowoczesnych środków jak Roentgen etc. Dlatego jeszcze raz z naciskiem powtarzam, że nic nie mam przeciw temu, by także badać stan głodu sposobami nowoczesnymi, ale nigdy się nie można zgodzić na to, by uzależnić tylko od tych sposobów stwierdzenie nadprzyrodzonego charakteru głodu.

Kto raz stanie na takim stanowisku, kto uważa jako sine qua non badania kliniczne, a za niewystarczające badanie obserwacyjne, ten popada w hiperkrytycyzm i ten godzi we wszystkie te wypadki głodu, które uznał Kościół za cudowne i które były stwierdzone tylko przez obserwację bez klinicznych badań.

Nie mówię już o tym, że Pan Profesor po przeczytaniu mojego rozdziału, aczkolwiek tak spóźnionym, uważa sam, że umieszczenie ustępu końcowego godzi w moje stanowisko zarówno w książce, jak i w obecnej mej polemice z Deutschem. Ja to czułem od pierwszej chwili, ale nie chciałem przykrości czynić Panu Profesorowi jasnym wypowiedzeniem tego, iż niepodobna jest żądać ode mnie, ażeby zwalczając Deutscha i Ewalda przytaczał na dowód pracę, która wprawdzie częściowo występuje przeciw Deutschowi, ale w istocie rzeczy uważa obserwację pierwszą tak jak Deutsch za zupełnie niedostateczną. Teraz już muszę Panu Profesorowi to otwarcie powiedzieć $\mathrm{w}$ chwili, gdy mam to przeświadczenie, że Pan Profesor uwzględniwszy przynajmniej w głównych zarysach moje stanowisko, tych konsekwencji wyciągać nie będzie. Zresztą te konsekwencje są dziś sprzeczne z tym, co pan Profesor wyraża w swej pracy godząc się na to, że kliniczne zabiegi mają na celu zadośćuczynienie zainteresowaniom naukowym, ale nie są czymś istotnym $\mathrm{w}$ badaniu. Tylko ta rzecz nie jest wyrażona dosyć jasno i jest ułożona wobec tez przeciwnych.

Nie w „moim miłym salonie”, ale w sali klinicznej trzej lekarze czytali rozprawę Pana Profesora, którą dałem jednemu z nich do przejrzenia ze względu na zwroty językowe niemieckie. Nie wiedziałem nic o tym, że lekarz ów zaprosi do czytania swoich kolegów; jeden z nich objechał wszystkie kliniki, w nich praktykował i jest znakomicie z problemem obeznany. Otóż wszyscy trzej stwierdzili zgodnie, iż praca Pana Profesora posiada znakomite wartości naukowe, ale stwierdzili zarazem sprzeczności w poglądach Pana 
Profesora (te podaję w zestawieniu na osobnej kartce) ${ }^{\mathrm{c}}$ i orzekli, iż ostatni ustęp jest mętny i obniża wartość całej pracy. Powiedział mi zarazem ów lekarz, że w ogóle w medycynie uważa się dziś nie tylko w sprawie głodu, jak i innych nieraz badaniach, badanie detektywistyczne nieraz za ważniejsze od badań klinicznych. Te są niejednokrotnie dopiero w powijakach, kiedy tymczasem badania detektywistyczne nie zawodzą nigdy, gdy są dobrze przeprowadzone. (Oczywiście nie zależy tu na grze słów, ale każdy wie o tym, że pod detektywizmem rozumie się jedynie obserwację - nic więcej. Dlatego pod to ogólnie przyjęte określenie nie dadzą się podciągnąć konkretne zabiegi kliniczne).

Nie wchodzę w to, czy ten, czy ci lekarze mieli słuszność, ale to jest dla mnie wymownym przykładem, że nie może być mowy o przeprowadzeniu obserwacji, skoro jeden lekarz przeczy temu, co drugi powie. To schodzi po prostu ad absurdum, dlatego prosiłem Pana Profesora, by się ograniczył w swej pracy do zakresu, o jaki był proszony, t.j. by wykazać, że nie ma powodu pomawiania Teresy Neumann o oszustwo. Wszelkie wkraczanie w dziedzinę przyszłej obserwacji nie należy do tematu, wikła rzecz i może mieć pozory nielojalności przez przesądzenie kwestii wobec lekarzy, którym będzie badanie zlecone.

Niezależnie od tego wszystkiego pozwoli mi Pan Profesor i nie weźmie za złe jednej uwagi: Pan Profesor przypisuje Ewaldowi słuszność, tymczasem w rzeczy samej Pan Profesor nie stoi zupełnie na stanowisku Ewalda, ale na wręcz przeciwnym; czyli Pan Profesor mówiąc o tym, że Ewald ma słuszność, podsuwa mu myśl własną, której on nie miał, czyli przemienia Pan Profesor sens jego słów. Pan Profesor podsuwa mu bowiem myśl, jakoby on uważał, że za mało było jeszcze zabiegów klinicznych. Tymczasem on ma zupełnie co innego na myśli. On sądzi, że w obserwacji, a nie w klinicznych zabiegach jest jakaś niewytłumaczona luka. Dlatego pan Profesor pochwalając Ewalda jest w istocie w sprzeczności z nim.

Daruje Pan Profesor, że powiem drastycznie. Ale Panu Profesorowi nie przysługuje prawo cytowania Ewalda przy zupełnie przeistoczonym sensie jego słów. Bo tak Ewald ani myślał, ani pisał.

Tak samo Pan Profesor staje przeciw całej opozycji lekarskiej wobec Konnersreuth na stanowisku jej przeciwnym, Pan Profesor przelicytował całą opozycję w radykaliźmie i powątpiewaniu. Dla opozycji bowiem [... ${ }^{\mathrm{d}}$ inspiratora Deutscha jest obserwacja punktem saliens ${ }^{159}$ kwestii, a nie zabieg kliniczny.

I każdy tej opozycji pod tym względem musi przyznać słuszność, bo jeśli kto nie je i nie pije choćby przez dwa tygodnie, a na wadze nie traci, to chociażby dwa tygodnie były za małą ilością czasu dla wytrzymałości niejedzenia, to jednak dwa tygodnie bez utraty ostatecznej wagi są zupełnie wystarczające, ażeby stwierdzić objaw niedający się w naturalny sposób wytłumaczyć. Przypuszczenie, że wytłumaczenie tego zjawiska stanie się możliwe przy lepszej aplikacie klinicznych zabiegów jest po prostu niemożliwe. Albowiem nie ma żadnej współmierności pomiędzy zabiegiem klinicznym a tego rodzaju objawami. To przeświadczenie podstawowe tkwi u wszystkich doktorów, którzy

Zob. załącznik niżej.

Brak tekstu.

159 Łac.: punkt główny, zasadniczy. 
zwalczają Konnersreuth, nie wyłączając Deutscha. I trzeba powiedzieć, że on uciekając przed konkluzją, że to jest fakt niedający się naturalnie wytłumaczyć jest przynajmniej konsekwentny z założeniem, o jakim mówiłem i dlatego przypuszcza oszustwo. I ja musze szczerze powiedzieć, że mimo całej potworności oskarżeń Deustcha, ja jednak przenoszę jego wywód nad Pański. Bo brak utraty wagi po dwóch tygodniach niejedzenia i niepicia jest zjawiskiem tak przechodzącym wszelkie warunki, iż jest ono albo faktem nadprzyrodzonym, albo fałszem i oszustwem. Zabieg kliniczny w tej sytuacji choćby nie wiem jaki niczego wyjaśnić nie potrafi. Dlatego i mnie spotyka niesłuszny zarzut Pana Profesora, jakobym metody „detektywistyczne” przeciwstawiał metodom klinicznym.

Nie ja jestem tylko na równi z całą opozycją lekarską przeciw Konnersreuth przeciwnikiem wyśrubowywania znaczenia klinicznego tam, gdzie zabieg kliniczny może mieć co najwyżej znaczenie dla zainteresowań naukowych, ale żadnego nie ma znaczenia dla tłumaczenia zjawisk, które się w sposób naturalny wytłumaczyć nie dadzą.

Zresztą to samo wyraził i Pan Profesor w tekście swojej pracy, tylko zapewne przez niedopatrzenie pozostawił Pan Profesor konkluzję z tym założeniem sprzeczną. Ta sprzeczność musi uderzyć każdego i uderza rzeczywiście.

Muszę jeszcze przy tej sposobności sprostować pewien szczegół, który niedokładnie podałem. Profesor Kmietowicz był u mnie nie w związku z pracą Pańską, z którą zupełnie się zgadza, lecz w związku z projektem czeskiego doktora co do ponownej obserwacji Teresy Neumann.

Ponieważ miałem temu ostatniemu dać odpowiedź, a Prof. Koskowskiego nie było, więc pytałem o to p[ana] Docenta Kmietowicza, oczywiście, że on mówił o zabiegach klinicznych, ale też w przeciwieństwie do innych domagał się tylko 10 dni obserwacji. Tyle dla wyjaśnienia tego szczegółu.

Dziękując Panu Profesorowi za łaskawe względy dla mego „salonu” mogę zapewnić Pana Profesora, że nikt z tych, co u mnie byli nie zna Benedykta XIV i jego rozprawy o głodzie, która była podstawą dla moich wszystkich wniosków.

Pan Profesor daje mi radę, aby o Teresie Neumann nie pisać. Wierzę, że ta rada płynie $\mathrm{z}$ najlepszego serca i intencji Pana Profesora i jestem o tym przekonany, ale chyba Pan Profesor zdaje sobie z tego sprawę, że po całorocznej pracy, po umowach z nakładcami, po zaawansowanym druku jest taka rada naprawdę bardzo spóźniona. Cenię ją, jak zawsze wszystko, co od Pana Profesora pochodzi, ale contra factum non est argumentum. Ja jednak wcale nie jestem zdania by nie pisać, albowiem uważam, że problem stygmatyzacji przeżyje zarówno mnie, jak Hitlera, jak Teresę Neumann. Ja piszę dla przyszłości.

Zbyt dobrze znam Pana Profesora i nazbyt polegam na Jego życzliwości i przyjaźni dla mnie, ażebym przypuścił, by Pan Profesor mógł wziąć mi za złe me bardzo szczere i otwarte słowa.

Przeciw Katarzynie Emmerich podnoszono zarzut, że jest oszustką, a pomimo tego jej kanonizacyjny proces jest w toku.

Łączę dla Pana Profesora wyrazy oddane mej głębokiej czci.

P.S. Prof. Koskowskiego niestety nie mogłem widzieć z powodu jego wyjazdu do Warszawy. 


\section{Sprzeczności}

1) Str. 5a: „Wykonanie takich badań nie było koniecznie potrzebne dla potwierdzenia tak ścisle przeprowadzonej kontroli".

2) $Z$ jednej strony czytelnik odnosi wrażenie, jakby autor artykułu za nic sobie miał pierwszą obserwację.

3) Str. 13: „[...] co razi wszelkie rozumowanie fizjologiczne i sprzeciwia się zwykłemu «sens commun» tak dalece, że prof. Ewald kończy swój raport żądaniem potwierdzenia tych badań w jakiejś klinice [...]. Rzecz jasna, że ma on rację".
Str. 6. „Nie wykonano niektórych prób, które mogłyby rzucić pełniejsze światło na przebieg procesów fizjologicznych".

$\mathrm{Z}$ drugiej strony pisze na str. 7: „w próbach dokonanych przez Ewalda i jego współpracowników występuje niezwykłość metabolizmu".

Str. 14: „Moim zdaniem kliniczne badania są niewystarczające". Jeżeli badania kliniczne są niewystarczające i jeżeli wymaga się do ponownych badań aparatury, której żadna klinika nie posiada, to tym samym Ewald nie ma racji.

\section{Dokument 52}

Oryg.: AFKDOPW, teczka 139: Spuścizna abp. Józefa Teodorowicza, sygn. 1291/365 [5], List prof. Stefana Dąbrowskiego do abp. Józefa Teodorowicza, Puszczykowo Stare 31 I 1938 r.

Puszczykowo Stare k. Poznania, 31/I 1938

Ekscelencjo ${ }^{\mathrm{a}}$,

Najprzewielebniejszy Ks. Arcybiskupie,

Pozwalam sobie przypomnieć Jego łaskawej pamięci moją prośbę dotyczącą tekstu niemieckiego owej mej rozprawki o Teresie Neumann ${ }^{160}$. Czy rzecz ta będzie w tekście niemieckim przesłana przed jej drukowaniem? Byłoby to może najlepiej, by nie poprawiać korekty. Będę J[ego] Ekscelencji niezmiernie zobowiązany za słówko odpowiedzi w tej materii.

Druga rzecz dotyczy Zosi. X. kanonik Bogdanowicz pisał prosząc o artykuł do „Gregoriana". Otóż, za pamięć o Zosi gorąco pragnę podziękować! Za moją namową Zosia zaczęła pisać i pisała już w tym tygodniu do „Myśli Narodowej” drugi większy artykuł o „Polityce narodowej i wskazaniach społecznych Encyklik” (z powodu uchwał I-go plenarnego Synodu Polskiego).

\footnotetext{
a Tekst pisany czarnym atramentem na 3,5 stronicach papieru formatu A4.

160 AFKDOPW, teczka: Spuścizna abp. Józefa Teodorowicza, bsygn., S. Dąbrowski, Paradoxer metabolismus im Falle der Therese Neumann von Konnersreuth, bmr, ss. 18, mps.
} 
Widzimy znaczne niebezpieczeństwo w rozwijającej się demagogii w sprawie agrarnej w sferach katolickich, a nawet wśród kleru ośmielonego do parcelowania większej własności w myśl wskazań „Rady Gospodarczo-Społecznej przy Prymasie Polskim”, artykułów „Kultury” i całej demagogii Ks. Brossa, Dyrektora Instytutu Akcji Katolickiej. Ostatnio umieścił on artykuł Ks. Piwowarczyka w „Kulturze” pt.: „Katolicym a sprawa agrarna". Już sam tytuł wskazuje na brak jakiejś równowagi i umiaru umysłu, jeśli zestawia się w tytule tak niewspółmierne pojęcia!

W gruncie rzeczy ci pisarze duchowni społeczno-chrześcijańscy są totalistami i wraz z Ks. Biskupem Kubiną nie szanują zasady własności prywatnej. Wobec tego w pierwszym artykule w „Myśli Narodowej” Zosia napisała „O manowcach katolickiej myśli społecznej”, uderzając w „Studium katolickie społeczne” z lata ub[iegłego] r[oku] i w zasadę ks. Madeya aprobowaną w druku przez Ks. Brossa, aby Akcja Katolicka zajmowała się parcelacją (sic). Otóż to! Na zjeździe Sodalicji pań wiejskich w grudniu ub[iegłego] r[oku] odbytym w Poznaniu, dzielono grunta zamiast myśleć o uświęcaniu dusz, ku zdumieniu wielu Pań z Kongresówki.

Dlatego Zosia - jak sama mówi, że jest potrzebna jako „Baba z miotłą” (w każdym razie Baba jest piękna) - pragnie w „Gregoriana” napisać rzecz o własności, by udając się pod opiekuńcze skrzydła Ekscelencji z tego lwowskiego [... $]^{\mathrm{b}}$ zrobić wypad na różnych katolickich demokratów. Czy można liczyć na łaskawe względy Ekscelencji i Ks. Redaktora? Mieszanie się Akcji katolickiej do czynnej polityki i powoływanie się wciąż na Ojca św. doprowadzi do niebywałego zamętu.

Niedawno dziekanowi Winiarskiemu na parę tygodni przed wybuchem powstania w Hiszpanii mówił w Madrycie jego Arcybiskup, że Hiszpania idzie do wojny domowej dlatego także, że Kościół poszedł na rękę katolicko-społecznemu ruchowi Sil Rublesa, zamiast oprzeć się na ruchu narodowym nie tak radykalnym.

Temuż koledze w Paryżu mówił Louis Marin, znany polityk i gorący przyjaciel Polski, że radykalizm społeczny w Hiszpanii duchowieństwa nie był hamowany z Rzymu i przyczynił się walnie do wybuchu rewolucji.

Jeżeli do reform Poniatowskiego pośrednio przyczyni się zarówno Rada Gospodarczo-Społeczna przy Prymasie Polski, wciągając w politykę społeczną autorytet Stolicy prymasowskiej, to jest jasnym, że za nią idzie demagogia kleru. Dokąd zajdziemy? Niebezpieczeństwo jest groźne. Dlatego „Baba z miotłą” prosi o gościnę w „Gregorianum".

Łączę wyrazy głębokiego szacunku, czci i synowskiego oddania

P.S. Proszę o wiadomości, jak zdrowie Ekscelencji?

Stefan Dąbrowski

b Wyraz nieczytelny. 


\section{Dokument 53}

Kopia: AFKDOPW, teczka 128 i 136: Spuścizna abp. Józefa Teodorowicza, sygn. 1295/365 [5] i 1292/365 [5], Kopia listu abp. Józefa Teodorowicza do prof. Stefana Dąbrowskiego, Lwów 6 II 1938 r.

Kochany ${ }^{a}$ Panie Profesorze!

Lwów, dnia 6 II 1938 r.

Przekazałem sprawę wiadomą Ks. Bogdanowiczowi, który jednak twierdzi, że artykułu obiecanego jeszcze na sierpień wcale nie otrzymał i już sądził, że Pani zrezygnowała $\mathrm{z}$ napisania. Musi być $\mathrm{w}$ tym jakieś nieporozumienie i on sam napisze do Pana Profesora.

Po wysłanym moim telegramie do Pana Profesora przesłał mi Dr Hynek z Pragi swoją odpowiedź Doktorowi Deutschowi, której fragment przesyłam Panu Profesorowib. Odpowiedź Hynka już się drukuje. Artykuł Hynka zrobił na mnie wprost wstrząsające wrażenie. Jest to odbicie i odzwierciedlenie zasadniczego stanowiska Kościoła, które rozróżnia pomiędzy nadzorem a badaniem klinicznym. Nikt nie ma prawa żądać od kogoś poddawania się zabiegom klinicznym. W sprawie głodu natomiast Kościół wyłącznie ograniczał się tylko do stwierdzenia faktu za pomocą nadzoru. Między cudami w Lourdes a tą kwestią nie ma analogii, bo za uzdrowienia w Lourdes Kościół nie bierze odpowiedzialności. Natomiast za stwierdzenie faktów niejedzenia, w bullach kanonizacyjnych Kościół jest odpowiedzialny. Zresztą wedle trafnego określenia Hynka komisja lekarska z Lourdes jest tylko potwierdzeniem stanowiska Kościoła.

To jasne, zdecydowane a tak uzasadnione rozróżnienie przez Hynka pomiędzy nadzorem a klinicznymi zabiegami, między zupełną wystarczalnością nadzoru zgodnie ze stanowiskiem ogółu lekarzy a czysto naukowym zaangażowaniem, pomiędzy tym czego można się spodziewać i domagać od badanego a czego się domagać nie wolno postawiło mnie wobec kwestii sumienia. Zadałem sobie pytanie: czy mi wolno jest przyczyniać się przez publikację choćby znakomitej rozprawy naukowej, choćby autora, dla którego jestem najbardziej oddany, która jednak w ostatecznej swej konkluzji jest przeciwna normie Kościoła i głosząc niezbędność klinicznych zabiegów podważa fakty uznane przez Kościół w bullach kanonizacyjnych za niezbite? I tu już nie chodzi o Konnersreuth, ani o Teresę, ani o trudności i przykrości moje osobiste, ale tu idzie mi wprost o kwestię sumienia zwłaszcza, że przez publikację Hynka kontrast zasadniczy stanie się jawny i publiczny.

Odpowiedziałem sobie, że mi tego uczynić nie wolno. Wolno mi ostatecznie przyjąć znakomitą pracę do stronicy 13 (do słów: „stoimy wobec jakiegoś paradoksu fizjologicznego") z zastrzeżeniem wyraźniejszego rozgraniczenia norm Kościoła od zainteresowań uczonych - mimo, że autor uchyla się od wszelkiej konkluzji, co jest niezawodnie stroną bardzo ujemną, ale do strawienia możliwą; natomiast poddawać

\footnotetext{
a Kopia maszynowa i rękopiśmienna na trzech stronicach papieru formatu A4. Brak zakończenia i autografu autora pisma. W lewym górnym rogu karty tytułowej nota czarnym atramentem: „Prof. Stefan Dąbrowski, Puszczykowo”.

b Brak owego dokumentu.
} 
warunki obserwacji, których ze stanowiska moralnego nie ma się prawa żądać i uzależniać stwierdzenia niejedzenia nie od obserwacji chociażby najdłuższej, ale od klinicznych zabiegów - tego chociażby pośrednio czynić mi nie wolno. Już nie mówię o tym, że ani Deutsch, ani Ewald, który zupełnie co innego twierdzi niż to, co Pan Profesor o nim mówi, ani Heermann, a więc cała opozycja przeciw Konnersreuth na tę drogę nie weszła. To już mnie nie obchodzi i do tej kwestii się nie mieszam, ale tamto ma dla mnie zasadnicze moralne znaczenie. Dlatego ze względu na ostatnią konkluzję Pana Profesora od str. 13 - którą mimo przedstawień moich i próśb Pan Profesor podtrzymuje - zmuszony jestem, choć $\mathrm{z}$ wielkim bólem a nawet zawodem zrezygnować $\mathrm{z}$ tego znakomitego zresztą artykułu. Mówię o zawodzie, bo chyba nie jestem winien temu, że książki mojej przed rokiem przysłanej Pan Profesor nie przejrzał zupełnie i dlatego jak sam mi pisze, nie wiedział, o co mi idzie. Gdyby Pan Profesor ustęp odnośny przed rokiem był przejrzał, nie miałbym i nie mógłbym mieć o to pretensji, iżby mi Pan Profesor na moją propozycję odpowiedział odmownie. Dziś nie mogę utaić poczucia zawodu po całorocznym zwlekaniu, gdy mi już trudno na to zaradzić. Dodatkowo już tylko zaznaczam, że gdyby przed rokiem Pan Profesor uważnie przeczytał cały mój ustęp o niejedzeniu („Die Nahrungslosigkeit”), nie byłby Pan Profesor czynił aluzji do mego - jak łaskawie Pan Profesor nazywa - „miłego salonu”, w którym padam ofiarą sugestii., bo byłby się Pan Profesor przekonał, że już przed dwoma laty opierając się o powagi lekarskie kwestię tę rozebrałem wszechstronnie. W chwili wydawania mej książki, gdy już wydawnictwa cofnąć nie mogę, daje mi Pan Profesor radę, że lepiej było tej książki nie pisać. Ale zanim się wziąłem do jej napisania, wiele przewalczyłem ze sobą, przemedytowałem i badałem sytuację. Zdecydowałem się na ten krok w tym przekonaniu, że piszę dla przyszłości, choćby mi przyszło przegrać, po ludzku mówiąc, w ostatniej chwili. Ale i dziś nie przegrywam. Przegrywa moralnie Biskup regensburski, który nie przyjął propozycji Teresy Neumann, by uciec z domu i poddać się obserwacji. Odnośny tekst Hynka w załączeniuc.

Prosząc Pana Profesora o współudział miałem oprócz rzeczy samej i to jeszcze na myśli, ażeby wynieść sprawę polskiego uczonego zagranicę. Stać się może, że jeżeli praca Pańska ukaże się w całości, zwróci się przeciwko mnie, a wesprze Deutscha, bo wprawdzie z jednej strony mu wskaże na jego fatalną i głupią metodę, ale zarazem wskaże, da mu zrozumieć, że do celu, do którego zmierzał, tj. zupełne unieważnienie pierwszej obserwacji, można iść inną drogą, tj. drogą nigdy niekończących się klinicznych zabiegów... Ale to już trudno, za to już nie odpowiadam. W każdym razie wszystko to już są względy uboczne wobec względu zasadniczego, który Panu Profesorowi wyłuszczyłem wyżej.

\footnotetext{
c Brak dokumentu.
} 


\section{Dokument 54}

Oryg.: APANP, sygn. P III - 116, teczka 86, List abp. Józefa Teodorowicza do prof. Stefana Dąbrowskiego, Lwów 24 II 1938 r. Kopia: AFKDOPW, teczka: 128, Spuścizna abp. Józefa Teodorowicza, sygn. 1290/365 [5].

Lwów, 24 II 1938 r.

Kochany ${ }^{a}$ Panie Profesorze,

Proszę darować, że dopiero teraz odsyłam tłumaczenie pracy Pana Profesora, ale było wiele utrudzenia $\mathrm{z}$ ustaleniem tłumaczenia zwrotów technicznych niemieckich, oparło się to ostatecznie o doktora tutejszego znającego doskonale język niemiecki, który jednak zawalony pracą nie mógł swych poprawek tekstu tak rychło uskutecznić jakbym tego pragnął.

Jak Panu Profesorowi zapowiadałem, rozmówiłem się z Prof. Koskowskim, który mi wprost powiedział, że miał wrażenie z Pańskiej pracy, że chodzi Mu głównie o zainteresowania naukowe. Powiedział $\mathrm{mi}$, że rozumie Pana Profesora doskonale jako badacza naukowego bo wiem, czym byłby dla Niego taki okaz jak Teresa Neumann i jak wielkie byłoby Jego zaciekawienie przemianami w jej organizmie. Z drugiej jednak strony zgodził się na to, że obserwacja sama bez klinicznych zabiegów przez czas odpowiedni przy nieutraceniu równoczesnym wagi jest czymś., co się wyjaśnić nie da.

Wobec tego zwracam się raz jeszcze z gorącą prośbą do Pana Profesora, ażeby chciał opuścić te ustępy, które badania kliniczne przedstawiają za niezbędne w obserwacji kościelnej. Proszę mi wierzyć, że istotnie wszelkie obserwacje Kościoła na które się powołują Bulle kanonizacyjne polegają jedynie na samej obserwacji, którą nazwałem za Dr. Hynkiem detektywistyczną. Nie ma tu żadnego zestawienia z cudami w Lourdes. Pominąwszy już, że te cuda odnoszą się do chorób a nie do głodu, to jednak za te badania Kościół nie bierze żadnej odpowiedzialności, podczas gdy za badania, które są podstawą Bull kanonizacyjnych - bierze odpowiedzialność. Przy tym Lourdes zajmuje się także konstatowaniem faktów uzdrowień na podstawie materiału dowodowego zebranego przez komisję w Lourdes. Klinicznych obserwacji z reguły w Lourdes nie przeprowadzają.

Ponieważ mam pełną nadzieję, że Pan Profesor zgodzi się na moją prośbę, nie przesyłam jeszcze końcowego zakończenia, jedynie tylko daję wzmiankę o domku szklanym, która w łączności z całą propozycją musiałaby być przystosowana właśnie do obserwacji klinicznych.

Przy tej sposobności nie chciałbym, ażeby Pan Profesor sądził, jakobym tylko pod wpływem niepowołanych głosów przedstawiał moją rację. Już ze stanowiska Prof. Koskowskiego wynika, że tak nie jest. Ale niezależnie od tego rozmawiałem z Dr. Kmietowiczem nie o Pańskiej pracy, którą bardzo pochwala, ale pytałem o zdanie, jak się ma urządzić obserwacja Teresy Neumann na podstawie listu Dr. Hynka, któremu musiałem dać odpowiedź.

\footnotetext{
a Tekst pisany na 3,5 stronicach maszynowo z wyjątkiem autografu, na papierze formatu A4.
} 
Udałem się zaś do innego lekarza, który się podjął bardzo trudnego zadania poprawienia (korekty) niemieckich zwrotów. Nie wiedziałem o tym, o czym mi później powiedział ów lekarz, że dobrał sobie dwóch lekarzy i we trójkę pracę Pana Profesora przeczytali. Wszyscy zgodzili się na to, że praca Pana Profesora jest znakomita, tylko końcowe ustępy są słabsze przez pewną chaotyczność, a nawet sprzeczność. Zresztą z nikim poza tym, prócz z p[anem] Koskowskim o Pracy Pańskiej nie mówiłem.

Jak Pan Profesor widzi, nie chciałem nawet Panu Profesorowi o tym pisać, ażeby Go nie martwić. Mnie nie obchodzi ani chaotyczność, ani sprzeczność, tylko to, o czym pisałem. A mianowicie:

- że nikt nie ma prawa wymagać od Teresy Neumann, aby się poddała klinicznym zabiegom;

- że zabiegi kliniczne są niczym wobec tego, co wykazała obserwacja, że Teresa Neumann przez dwa tygodnie i więcej nie pobierała żadnych pokarmów i napojów przy równoczesnym nieubywaniu na wadze;

- że tradycja Kościoła i argumenty Bull kanonizacyjnych Kościoła są oparte jedynie na obserwacji a nie na zabiegach klinicznych.

W umowie pomiędzy Biskupem Buchbergerem a Neumannem wyraźnie będą wykluczone zabiegi kliniczne.

Posyłam zresztą Panu Profesorowi odnośny ustęp pracy Dr. Hynka, na który się w mej pracy powołuję. Praca ta będzie wkrótce ogłoszona drukiem.

Jeżeli wolno mówić o nieporozumieniach między nami, wynikają one z tego, że listowne porozumienie się jest bardzo trudne, a nawet - proszę darować - wynikają z tego, o czym napomknąłem przed naszym wspólnym przyjacielem, że Pan Profesor mojej pracy nie czytał. Tam bowiem całe moje stanowisko jest wyjaśnione i uzasadnione. Ale nie mam najmniejszego żalu do Pana Profesora, chcę tylko stwierdzić, co stwierdzić należało.

Muszę odpowiedzieć też Panu Profesorowi na aluzję, że lepiej by było, gdybym książki tej nie pisał. Trudno - już ją napisałem. Ale gdybym jej nie pisał, to bym ją jednak napisał, gdyż uważam ją za konieczne dopełnienie mej pierwszej pracy i piszę ją dla przyszłości nie oglądając się na chwilowe i aktualne względy.

Co do uwag Pana Profesora o katolicyzmie - zupełnie je podzielam. Pański wychowanek i pupil nie zdał egzaminu. Niektórzy z tych katolików nie zdają sobie sprawy, że są tylko instrumentem do zalicytowania przez radykalizm, który przez nich rozgrzeszony, nie oglądając się na nich pójdzie poza prawo.

Jeżeli Pani napisze artykuł do „Gregoriany”, to musi wpierw przeczytać artykuł Turnau'a, który ukazał się w „Kulturze”, a jest skierowany przeciw ziemiaństwu ${ }^{161}$.

Łączę dla Pana Profesora i dla Pani moje wyrazy oddane czci głębokiej i szacunku

† Teodorowicz

${ }^{161}$ S. Turnau, Deklaracja Rady Społecznej a ziemianie, KTLAS, 3(1938), nr 8, s. 2-3. 


\section{Dokument 55}

Kopia: AFKDOPW, teczka 136: Spuścizna abp. Józefa Teodorowicza, sygn. 1289/365 [5], List abp. Józefa Teodorowicza do prof. Stefana Dąbrowskiego, Lwów 6 III 1938 r.

\section{Przezacny ${ }^{\mathrm{a}}$ Panie Profesorze,}

Muszę jeszcze w uzupełnieniu mojego listu napisać Panu Profesorowi, jak się przedstawia formalna sprawa $\mathrm{z}$ wydawnictwem. Otóż księgarnia wyznaczyła termin ukończenia pracy na listopad $u[$ biegłego] $r[o k u]$. Ponieważ praca nie była gotową, odwlokłem sprawę na koniec grudnia, ale był to warunek już sine qua non ${ }^{162}$, gdyż wraz z książką niemiecką miało się również ukazać i tłumaczenie francuskie, a wydawca francuski zastrzegł sobie, że poza ten termin już dalej nie pójdzie. Praca jednak do końca grudnia nie była gotową, ale następstwem tego jest, że praca francuska odpada i nie ukaże się wcale. Wprawdzie ogromnie mi tej pracy szkoda, ale sądziłem, że będę miał wolność co do czasu teraz. Tymczasem zaczynam otrzymywać nowe urgensa $^{163}$, już drugi list od wydawcy, by się już dłużej z pracą nie ociągać. Dlatego bardzo będę zobowiązany Panu Profesorowi, jeżeli mi zechce odesłać natychmiast odpowiedź, a zarazem stosownie do swej odpowiedzi zechce Pan Profesor przysłać mi przede wszystkim pracę Hohna i inne książki.

Bardzo przepraszam Pana Profesora i jest mi to niesłychanie przykro, że Pana Profesora tam nękam, ale niestety jestem w położeniu przymusowym. Mam wszelką nadzieję, że Pan Profesor moje stanowisko uzna i w oczekiwaniu tak cennej pracy Pana Profesora łączę wyrazy prawdziwie oddane mojego głębokiego poważania i przyjaźni.

\section{Dokument 56}

Oryg.: AFKDOPW, teczka 139: Spuścizna abp. Józefa Teodorowicza, sygn. 1287/365 [5], List prof. Stefana Dąbrowskiego do abp. Józefa Teodorowicza, Puszczykowo Stare 14 III 1938 r.

Puszczykowo k. Poznania 14 III 1938 r.

Ekscelencjo ${ }^{a}$, Najdostojniejszy Ks. Arcybiskupie,

Zupełnie niespodzianie, po ustaleniu tekstu polskiego mej rozprawki o metabolizmie u Teresy Neuman, otrzymałem od Ekscelencji tekst niemiecki bez zakończenia, w którym piszę, że nowe badania, zalecane ostatnio przez Episkopat bawarski i Święte Officium, winne być wykonane nie w zwykłej klinice, lecz wzorem amerykańskich badań w kalorymetrze respiracyjnym.

\footnotetext{
a Tekst pisany maszynowo i na jednej stronicy papieru formatu A4. Brak autografu autora tekstu.

${ }^{162}$ Łac.: warunek konieczny.

163 Z łac.: ponaglenia.

a Tekst pisany maszynowo na czterech stronicach papieru formatu zeszytowego. Autograf pisma sporządzony czarnym atramentem.
} 
Ograniczenie się do wyciągnięcia wniosków z badań Ewalda, które w każdym razie nie są wyczerpujące nawet $w$ tych warunkach, $w$ jakich były wykonywane, nie może stanowić ostatecznego programu w badaniu przemiany materii u T[eresy] N[eumann]. Skoro Episkopat bawarski powołując się na Święte Officium uważa, że dalsze badania są wskazane, to czyż mogę zająć inne stanowisko?

Zastanawiam się przeto, jak mamy postąpić, aby salwować obiektywizm naukowy i uczynić zadość życzeniom Ekscelencji. Najprostsze wyjście byłoby, aby pracę moją ogłosił pod swoim nazwiskiem dr Radło, który i tak podpisuje całą polemikę pióra Ekscelencji. Jeżeli zgodził się on podpisać traktat o mistycyzmie, to tym bardziej może on podpisać rozprawkę moją o metabolizmie.

To byłoby wyjście najprostsze. Drugi sposób polegałby na tym, abym w czasopiśmie lekarskim albo innym ogłosił tekst polski mej rozprawki, a dr Radło wziąłby z niej to, co najbardziej odpowiadałoby polemice z dr. Deutsche'em.

Czekałem na przyjazd prof. Jurasza, aby z nim odbyć naradę, ponieważ doskonale zdaję sobie sprawę, że bez uwzględnienia świeżo podanych życzeń Episkopatu bawarskiego mogę być posądzony, że Ewaldowskie badania są wystarczające i ostateczne, gdy dla Episkopatu i Świętego Officium są one niewystarczające, jeżeli po nich nastąpił okres dziesięciu lat nieprzyjmowania pokarmów i napojów przez T[eresę] N[eumann]. Przeciwnicy od razu podchwycą moje naukowe zacofanie, a konieczność dalszych rygorów obserwacyjnych wymaganych przez hierarchię kościelną. Dlatego też postanowiłem zarzut ten uprzedzić i nie bronić się przed możliwością i użytecznością dalszych badań.

Jego Eminencja Ks. Kardynał Prymas, który moją rozprawę czytał, podziela raczej mój pogląd i radzi nie bronić się przed możliwością dalszych badań, uważając, że punkt widzenia Episkopatu bawarskiego jest nakazany ostrożnością i przesądza do pewnego stopnia moje stanowisko, jako badacza naukowego.

Prof. Jurasz jutro względnie pojutrze da mi odpowiedź i wówczas będę mógł ostatecznie napisać Ekscelencji, jak myślę wybrnąć z nowych trudności.

W niedzielę razem z Zosią słuchaliśmy wspaniałego kazania Ks. Arcybiskupa. Dziękujemy za nie z głębi serca i prosimy przyjąć od nas obojga wyrazy najgłębszej czci i oddania

b-St [efan] Dąbrowski ${ }^{-b}$

P.S. W poniedziałkowym numerze „Warsz[awskiego] Dzien[nika] Narodowego”164 jest artykuł wstępny, tłumaczący Hitlera za zabór Austrii i krytykujący traktat Wersalski. Zapewne napisał go S[tanisław] Kozicki ${ }^{165}$. Jesteśmy nań oburzeni, jako na objaw nie

b-b Tekst sporządzony czarnym atramentem.

164 „Warszawski Dziennik Narodowy” - polskie czasopismo wydawane w latach 1935-1939 w Warszawie, jako kontynuacja „Gazety Warszawskiej” zamkniętej przez władze sanacyjne za skrajnie prawicowe poglądy.

${ }^{165}$ Kozicki Stanisław (1876-1958), dr filozofii, od 1902 r. należał do Stronictwa Narodowo-Demokratycznego, dziennikarz i redaktor czasopism endeckich „Gazety Warszawskiej” i „Gazety Polskiej” (Moskwa), sekretarz generalny delegacji polskiej na konferenecję pokojową w Paryżu po I wojnie światowej, od 1920 r. mieszkał w Poznaniu: redaktor „Przeglądu Wszechpolskiego” i „Kuriera Poznańskiego”, w 1922 r. wszedł do Sejmu RP, 1928-1935 senator, po 1945 r. drukował swe prace na łamach tygodnika „Kierunki”. Kozicki Stanistaw, w: Kto byt kim, s. 101. 
mniej pogańskiego nacjonalizmu, jak jest hitlerowski. Ci, którzy zwalczają masonerię, nie znaleźli słowa współczucia dla katolickiego kraju oddanego przez zdradzieckie Włochy, a zapewnie i masonerię świata na łup pogaństwa niemieckiego. Czy Ks. Arcybiskup nie zechciałby gwałtownie zaprotestować przeciwko takiemu stanowisku? Jest to bodaj ważniejsze, niż nasz spór o T[eresę] N[eumann].

\section{Dokument 57}

Oryg.: APANP, sygn. P III - 116, teczka 86, List abp. Józefa Teodorowicza do prof. Stefana Dąbrowskiego, Lwów 17 III 1938 r. Kopia: AFKDOPW, teczka 128: Spuścizna abp. Józefa Teodorowicza, sygn. 1285/365 [5].

Lwów, dnia 17 marca 1938 r.

Kochany ${ }^{\mathrm{a}}$ Panie Profesorze,

Bardzo dziękuję Panu Profesorowi za list Pański, który mi sprawił dużą pociechę. Bo nareszcie nie różnimy się właściwie w naszym stanowisku zasadniczym wcale.

Panu Profesorowi zależy całkiem słusznie na tym, aby Teresa Neumann była poddana obserwacji dlatego, że tego żądają Biskupi i domaga się Kongregacja.

Lecz ja w mej książce, a więc przed dwoma laty, pisałem to samo i robiłem starania, by druga obserwacja przyszła do skutku właśnie dlatego, że tego sobie życzyli XX. Biskupi. Takie samo stanowisko jest już zajęte przeze mnie w tej nowej pracy. W szczególności wspominam o projekcie Pana Profesora szklanego domu.

Tak samo nie będę o to kopii kruszył, jak długo ma trwać ta obserwacja - czy 2 tygodnie, czy jak tego żąda Deutsch - miesiąc. $Z$ tego względu nie mam nic przeciw, jeśli Pan Profesor wyrazi - jak Hohn to czyni - potrzebę nowej obserwacji.

Tak samo zaznaczył Pan Profesor w swej pracy różnicę zasadniczą pomiędzy samą obserwacją, która wystarczy dla stwierdzenia, iż nie ma oszustwa a klinicznymi zabiegami. Dzięki właśnie temu rozróżnieniu zgadzam się na to, aby prawie cała praca Pana Profesora była umieszczona. Prosiłem tylko o skreślenie ostatniego ustępu, który wywołuje u czytelnika wrażenie, że cały proces obserwacji polega na klinicznych zabiegach. Ten ustęp przyczynić by się mógł tylko do tego, że Neumann córki swej pod obserwację nie odda. Nikt bowiem nie ma prawa narzucać klinicznych zabiegów, a on się zastrzegł przeciw temu.

Już nie mówię o tym, o czym pisałem Panu Profesorowi poprzednio, tj. o zasadniczym stanowisku Kościoła w tym względzie zawartym w aktach i bullach kanonizacyjnych. Pomijając już inne względy, byłaby dla mnie ogromna szkoda, gdyby Pan Profesor sam swojej pracy nie podpisał, nie tylko ze względu na samą pracę i jej wartość, lecz zależało mi bardzo, by imię Pana Profesora w Niemczech jako uczonego zabłysło. Prosiłem Pana Profesora o udział i rzeczywiście praca Pana Profesora - według orzeczenia Prof. Koskowskiego - jest znakomitą.

\footnotetext{
a Tekst pisany maszynowo z wyjątkiem autografu, na 2,5 stronicach papieru formatu A4.
} 
Dodam tu jeszcze i to, że powoływanie się na Dr. Ewalda, iż ma słuszność, nie odpowiada stanowisku, jakie Dr Ewald zajął. Bo racje Dr. Ewalda są zupełnie inne niż racje Pana Profesora. Ewald nie apeluje do nowych klinicznych zabiegów, tylko do nowej „Überwachung”, czyli też do powtórzenia pierwszej Überwachung. Tymczasem Pan Profesor apeluje do nowych klinicznych zabiegów. Ale to już drobiazg, którego dotykam mimochodem. Dlatego sądziłem, że Pan Profesor może ogólnie zaznaczyć, bo tego domagają się Biskupi i żądać, by to Überwachung odbyło się w takich warunkach, jakie dzisiaj nauka za najlepsze przewiduje, tj. w szklanym domu.

O nowych zabiegach można by pisać z zastrzeżeniem, aby uchylić niejasność i nieścisłość, iż one dla samej obserwacji nie są konieczne, lecz mogą posłużyć dla zaspokojenia ciekawości lekarskiej. To zresztą wynika z założenia Pana Profesora.

Dziękuję Panu Profesorowi i Pani za słowa tak łaskawe, a dla mnie tak cenne, o moich przemówieniach $^{166}$. Zastosuję się też do życzenia Pana Profesora i w następnym przemówieniu, odpowiada mi to bardzo. A ta lekkomyślność, z jaką się u nas traktuje zabór Austrii ${ }^{167}$, a usadowienie się w środkowej Europie Niemiec, jest wprost nie do pojęcia! Trzeba istotnie zaślepienia takiego organu Związku Ludowo-Narodowego, ażeby Niemcom dostarczać materiału dla usprawiedliwienia ich gwałtu, który dziś spotyka Austrię, a jutro się na nas zamierzy. Polska staje się obecnie zupełnie osamotnioną: $\mathrm{z}$ jednej strony Niemcy, z drugiej strony przez nich popierana Ukraina, tam znów Litwa wroga, a w końcu Rosja. I w takich to warunkach obóz narodowy pieje prawie peany w cześć hitleryzmu.

Będę bardzo zobowiązany Panu Profesorowi, jeżeli zechce ostatecznie rozstrzygnąć całą sprawę z manuskryptem. Już trzeci urgens dostaję z Niemiec gdzie mi piszą, że dalej czekać nie mogą, gdyż sprawa przestanie być zupełnie aktualna.

Łączę dla Państwa moje bardzo serdeczne pozdrowienia i zawsze oddane wyrazy mej czci głębokiej

† Teodorowicz

J[aśnie] Wielmożny Pan Profesor

Stefan Dąbrowski

Puszczykowo

\section{Dokument 58}

Oryg.: AFKDOPW, teczka 139: Spuścizna abp. Józefa Teodorowicza, sygn. 1284/365 [5], List prof. Stefana Dąbrowskiego do abp. Józefa Teodorowicza, Puszczykowo Stare 24 III 1938 r.

Puszczykowo Stare, 24 III 1938

${ }^{166}$ Nawiązanie do transmitowanych przez Polskie Radio rekolekcji wielkopostnych głoszonych przez abp. Józefa Teodorowicza w dniach 6, 13, 20, 27 III, 3 IV i 10 IV 1938 r. we Lwowie. J. Teodorowicz, Kuszenie Chrystusa. Wielkopostne konferencje radiowe, Kraków 1938; M. Szczepaniak, Spirala pomówień czy walka o dusze? Wokót polityki w kazaniu radiowym abp. Teodorowicza, SSHT, 2013, t. 1, s. 129-146.

167 Aluzja do aneksji tzw. Anschlussu Austrii, dokonanego 12-13 III 1938 r. przez III Rzeszę. 


\section{Najprzewielebniejszy ${ }^{\mathrm{a}}$ Ks. Arcybiskupie!}

Jestem tak zajęty, że nie mogłem dotąd zająć się niemieckim tekstem mego artykułu o T[eresie] Neumann ${ }^{168}$. Odsyłam go z koniecznymi poprawkami bibliograficznymi oraz $\mathrm{z}[\ldots]^{\mathrm{b}}$ na str. 8 i 9. Co do spornego zakończenia to podaję projekt, który musi Ekscelencję zadowolić.

Właściwie po mojej stronie, tj. po stronie ostatniego [orzeczenia] Episkopatu Bawarskiego i Św[iętego] Officium domagających się jeszcze badania ponownego tego zjawiska są wszyscy moi koledzy specjaliści z prof. Juraszem ostatnio na czele, dalej Książę Metropolita Sapieha i Ks[iądz] Kardynał Prymas. Ks[iążę] Staś Czartoryski ${ }^{169}$, który tekst polski czytał i chciał go dać do przeczytania swej Matce księżnie Jadwidze ${ }^{170}$ naraził się tylko na burę. Księżna oświadczyła i bodaj słusznie, że tylko „męczymy biedną stygmatyczkę", czyniąc ją przedmiotem sporów teologicznych i lekarskich. Uważam, że księżna ma najzupełniejszą rację. Dlatego pragnąłbym rzecz tę zakończyć, bo doprawdy już nie mam czasu i ochoty więcej tą sprawą się zajmować, zwłaszcza, że osobiście nic nie mogę zrobić.

Czytałem rozprawę Ekscelencji tak polską, jak i niemiecką, po napisaniu już mej rzeczy. Nie mogła ona wpłynąć - rozdział o głodzie - na zmianę mej opinii. Np. nie mógłbym pójść tak daleko, jak prof. Dr Verweyen ${ }^{171}$, że skoro „Abnormität” ${ }^{7_{72}} \mathrm{u}$ „T[eresy] $\mathrm{N}$ [euman] możliwe jest w ciągu $15 \mathrm{dni}$, to tym samym ta rzeczywistość jest stwierdzoną i udowodnioną nie tylko $15 \mathrm{dni}$, lecz i 15 tygodni, i miesięcy, a nawet więcej możliwą była i jest".

Moje zakończenie jest dlatego potrzebne, aby nikt nie mógł wyciągnąć takiego wniosku, jak prof. Verweyen. Gdyby jednak taki wniosek był wyciągnięty, to rzeczywiście byłaby to największa krzywda wyrządzona mnie, jako badaczowi doświadczalnemu. Taki jest pogląd zarówno prof. Jurasza, jak i J[ego] E[minencji] Ks. Prymasa. Dlatego to właśnie dbam o to, aby pewnym koniecznym zastrzeżeniem z góry się zastrzec przed zbyt daleko idącymi wnioskami i ekstrapolacją 15 dni doświadczeń na lata całe.

Łączę wyrazy najgłębszej czci i oddania

Stefan Dąbrowski

PS. Dziękujemy wszyscy za wspaniałą naukę ${ }^{173}$. Niebywałe stanowisko Kozickiego zostało na [... $]^{\mathrm{c}}$ Głównym Str[onnictwa] Nar[odowego] ostro napiętnowane przez prof. [...].

a Tekst pisany czarnym atramentem na dwóch stronicach papieru formatu A4.

168 AFKDOPW, teczka: Spuścizna abp. Józefa Teodorowicza, bsygn., S. Dąbrowski, Paradoxer metabolismus im Falle der Therese Neumann von Konnersreuth, bmr, ss. 18, mps.

b Wyraz nieczytelny.

169 Czartoryski Stanisław Ignacy (1902-1982), syn Jadwigi i Witolda Czartoryskich, duchowny archidiec. krakowskiej, m.in. proboszcz par. Maków Podhalański oraz Katedry Wawelskiej.

${ }^{170}$ Czartoryska Jadwiga Helena Walentyna (1867-1941), z d. Dzieduszycka, żona Witolda Leona Czartoryskiego, księżna.

171 Osoba niezidentyfikowana

${ }^{172}$ Niem.: nieprawidłowość, nienormalność.

173 Aluzja do kolejnego kazania abp. Teodorowicza w ramach tzw. radiowych rekolekcji wielkopolskich $1938 \mathrm{r}$.

c Wyraz nieczytelny.

d Wyraz nieczytelny. 
Polska katolicka troszczy się tylko o stosunki handlowe z Austrią, które wbrew opinii p[ana] Becka ${ }^{174}$ będą głęboko wstrząśnięte.

\section{Dokument 59}

Oryg.: AFKDOPW, teczka 139: Spuścizna abp. Józefa Teodorowicza, sygn. 1283/365 [5], List prof. Stefana Dąbrowskiego do abp. Józefa Teodorowicza, Kraków 27 III 1938 r.

Kraków, 27 III 1938 r.

Najprzewielebniejszy ${ }^{\mathrm{a}}$ Ks. Arcybiskupie!

Byłem tutaj na posiedzeniu Akademii Umiejętności tzw. administracyjnym, które odbywa się corocznie w marcu.

Dziś przed wyjazdem słuchaliśmy w mieszkaniu Dra Mariana Godlewskiego ${ }^{175}$ wspaniałego kazania Ekscelencji.

Jakże są one ważne w tych chwilach tak rzeczywistego kuszenia szatana, który zbliża się teraz ponownie do kuszenia Narodu Polskiego!

Muszę wyznać Ekscelencji, żeśmy w Poznaniu mieli z młodzieżą dość kłopotu, na razie szczęśliwie załatwionego. Musiałem bądź jako Dziekan, bądź jako kurator przedstawić publicznie na walnych zgromadzeniach niektórych stowarzyszeń kandydatów, którzy muszą się wykazać, że krew żydowska jest dopiero w 3-cim pokoleniu wstecz.

Dowiedziałem się, że tego rodzaju nakaz został wydany przez środowisko lwowskie, zapewne przez „katolickiego hitlerowca”, jakim wydaje się być p[an] J. Bogdanowicz ${ }^{176}$.

Zapytywany przez Rektora Peretiatkowicza ${ }^{177}$ J[ego] Em[inencja] Ks. Prymas za pośrednictwem akad[emickiego] duszpasterza oświadczył, że takie uchwały są sprzeczne z dekretami I-go Synodu, potępiającymi rasizm pogański. Do tego polecenia zastosuje się Senat U[niwersytetu] Pozn[ańskiego] i nie zatwierdzi tych uchwał, jeśli będą powzięte.

Drugi kłopot był ze sprawą Kowna ${ }^{178}$. Również ze Lwowa przyszły bez uzgodnienia ze Str[onnictwem] Nar[odowym] dyrektywy, aby „maszerować na Kowno” i zgnębić „nikczemnego karła”, stwierdzając w uchwałach, że traktat Wersalski jest „świstkiem papieru” (sic!).

${ }^{174}$ Beck Józef (1894-1944), uczestnik wojny polsko-bolszewickiej 1920 r., 1922-1923 attaché wojskowy we Francji, 1926-1930 szef gabinetu ministra spraw wojskowych J. Piłsudskiego, 1932-1939 minister spraw zagranicznych, 1935-1939 senator RP, 1939-1940 internowany w Rumunii gdzie zmarł. Beck Józef, w: Kto byt kim, s. 90.

a Tekst pisany czarnym atramentem na dwóch stronicach papieru formatu A4.

175 Osoba niezidentyfikowana.

176 Osoba niezidentyfikowana.

177 Peretiatkowicz Antoni (1884-1956), dr nauk prawnych, habilitacja w 1914 r. na Uniwersytecie Jagiellońskim, 1914-1918 docent tamże, 1918-1919 prof. nadzwyczajny filozofii prawa i metodologii umiejętności prawniczych na Uniwersytecie Jana Kazimierza we Lwowie, 1919-1939 prof. zwyczajny nauki o państwie i prawie państwowym i 1945-1956 na Uniwersytecie Poznańskim, w roku akad. 1919/20 dziekan Wydziału Prawa tamże, w roku akad. 1920/21 prorektor, w 1936/37 rektor uczelni, 1930-1936 dyrektor Wyższej Szkoły Handlowej w Poznaniu, w roku akad. 1938/39 rektor Akademii Handlowej tamże, 1939-1947 sędzia Najwyższego Trybunału Administracyjnego, 1939-1944 prof. w Szkole Handlowej w Warszawie, po II wojnie światowej członek Stronnictwa Demokratycznego, autor publikacji z dziedziny historii doktryn państwowych, prawa międzynarodowego, publicznego i państwowego. Peretiatkowicz Antoni, w: WSB, red.

A. Gąsiorowski, J. Topolski, Warszawa-Poznań 1981, s. 561-562.

${ }^{178}$ Kowno - w okresie międzywojennym stolica państwa litewskiego. 
Na wiecu przeciwstawiłem się, jako delegat Senatu, tym pomysłom. Powiedziałem młodzieży:

1) że nie mają monopolu na patriotyzm i rozumienie zagadnień polit[yki] zagranicznej;

2) „nikczemny karzeł” - nie jest ze słownika narodowego (używał tego wyrażenia Piłsudski);

3) obalanie traktatu Wersalskiego młodzież polska winna pozostawić Hitlerowi, a nie pomagać mu w narzucaniu tej podstawy prawnej, którą podpisał wódz obozu nar[odowego] Roman Dmowski ${ }^{179}$ i razem z nim Paderewski ${ }^{180}$ i kilkanaście narodów;

4) Polska z r[oku] 1919 jest jedynym już, ale najważniejszym artykułem traktatu. Granice zachodnie $\mathrm{w}$ dużym niebezpieczeństwie.

5) marsz i zabór Kowna teraz nie jest w interesie Polski. Można to było zrobić w 1920, gdy na Kowno maszerował gen. Zagórski1 ${ }^{181}$, którego Piłsudski cofnął.

Ta polityka zaserwowana przez Lwów, w ostatniej chwili sprowadzona została na właściwe tory u nas. Ale podobno ta cała „dynamika” wychodzi od J. B[ogdanowicza]. Takie mamy wiadomości. [... $]^{\mathrm{b}}$

Łączę wyrazy głębokiej czci i oddania, z jakimi zawsze pozostaję dla Ekscelencji St[efan] Dąbrowski]

\section{Dokument 60}

Oryg.: AFKDOPW, teczka 139: Spuścizna abp. Józefa Teodorowicza, sygn. 1283/365 [5], List prof. Stefana Dąbrowskiego do abp. Józefa Teodorowicza, Puszczykowo Stare 3 IV 1938 r.

dnia 3 kwietnia 1938

Ekscelencjo ${ }^{\mathrm{a}}$, Najdostojniejszy Ks. Arcybiskupie!

Przed chwilą razem z Zosią wróciliśmy z plebanii, gdzie razem z naszym proboszczem słuchaliśmy przez radio, którego nie mamy, a raczej mieć nie chcemy - ostatniego kazania Ekscelencji! Mieliśmy wrażenie, że się ono nagle urwało. Czy dlatego, że Ks. Arcybiskup był już zmęczony, czy raczej dlatego, że piętnowani przez Ekscelencję „truciciele dusz”, zawiadujący w radio, nagle uważali za słuszne kazanie to przerwać. Będziemy bardzo Ekscelencji zobowiązani za słówko wiadomości, jaka była właściwa

179 Dmowski Roman (1864-1939), dr nauk przyrodniczych, 1907-1914 poseł do II Dumy rosyjskiej, w 1917 r. powołał do życia w Paryżu Komitet Narodowy Polski, reprezentował Polskę z I. Paderewskim na konferencji pokojowej w Paryżu, od 1920 r. przebywał w Polsce, w 1923 r. minister spraw zagranicznych, w 1928 r. założył Obóz Wielkiej Polski, uchodził za jednego z najwybitniejszych polityków obozu narodowego. Dmowski Roman, w: Kto byt kim, s. 93.

${ }_{180}$ Zob. w niniejszej publikacji: J. Wołczański, Listy abp. Józefa Teodorowicza do abp. Józefa Bilczewskiego, dokument 132.

181 Zagórski Włodzimierz (1882 - po 1927 r.), żołnierz armii Austro-Węgier, od 1918 r. służył w Wojsku Polskim, w 1924 r. mianowany generałem brygady, pracownik Ministerstwa Spraw Wojskowych - szef Departamentu Żeglugi Powietrznej, w 1926 r. więziony, rok później zaginął. P. Kowalski, Generał brygady Wtodzimierz Ostoja-Zagórski (1882-1927) - biografia, Toruń 2007, passim.

b Całe zdanie nieczytelne.

a Tekst pisany czarnym atramentem na dwóch stronicach papieru formatu A4. W lewym górnym rogu karty tytułowej nadruk firmowy: „Puszczykowo Stare k/Poznania. Tel. 26”. 
przyczyna nagłego urwania i niemożności dokończenia kazania, skoro niezakończone ono zostało słowem „Amen”, jak były wszystkie poprzednie?

W każdym razie, czy Ekscelencja świadom jest tego, że nagle słuchacze w całej Polsce przestali Go słyszeć?

Słyszelismy, jak ów turysta w turniach tatrzańskich poślizgnął się i stacza się w przepaść, zaczepiając się o lada wystający głaz. A potem było zdanie, że jedna jest tylko droga ratunku. I w chwili, kiedyśmy oczekiwali jakiegoś dłuższego zakończenia kazania, nagle audycję przerwano. Potem powiedział speaker, że nabożeństwo w kaplicy Matki Boskiej Ostrobramskiej jest skończone i kazanie również. To oświadczenie było zupełnie inne, niż zazwyczaj bywało przedtem, kiedy speaker uroczyście zapowiadał ukończoną audycję zarówno nabożeństwa, po którym „Kazanie wypowiedział: J[ego] Ekscelencja Ks. Arcybiskup Dr Józef Teodorowicz”. Tym razem widać było w „radio” dziwny pośpiech. Jeżeli może na przyszłą niedzielę doczekamy się nauki Ekscelencji, to prosilibyśmy o łaskawe powtórzenie w streszczeniu tego zakończenia, które do nas nie doszło.

Jako b[yły] polityk muszę zaznaczyć, że „interpelacja”, którą Ekscelencja skierował do Ministra Oświaty bez wymienienia adresata, z powodu trujących źródeł, które swój początek biorą w Uniw[ersytetach] ludowych, była bardzo mocna. W ogóle cała nauka była bardzo mocna, a i byli posłowie cieszyli się słuchając, jak dawny ich Dostojny kolega sejmowy - przed zamknięciem obecnej sesji - zdołał jeszcze zaatakować niebywały oportunizm prof. Świętosławskiego ${ }^{182}$ w stosunku do Zaw[odowego] Zw[iązku] Nauczycielskiego... W każdym razie rzeczą jest jasną, że polityki niepodobna się wyrzec w naszych czasach. Jesteśmy wszyscy przygnębieni zachowaniem się ks. kardynała I[n]nitzera ${ }^{183}$ i jego listem z owym zakończeniem: „Heil Hitler"184. Ks. Prymas uważał go za opokę katolicyzmu w Austrii. Jakże się zawiódł!

Łączymy wraz z żoną wyrazy najgłębszej czci i wdzięczności

St [efan] Dąbrowski

\section{Dokument 61}

Oryg.: APANP, sygn. P III - 116, teczka 86, List z Sekretariatu abp. Józefa Teodorowicza do prof. Stefana Dąbrowskiego, Lwów 18 XI 1938 r.

Wielce ${ }^{a}$ laskawy Panie Profesorze!

Lwów, dn[ia] 18 XI 1938 r.

182 Świętosławski Wojciech Alojzy (1881-1968), absolwent Wydziału Chemii Politechniki Kijowskiej, 1910-1917 docent Uniwersytetu Moskiewskiego, 1918-1939 prof. chemii fizycznej Politechniki Warszawskiej, dziekan, prorektor i rektor tejże uczelni, 1935-1939 minister Wyznań Religijnych i Oświecenia Publicznego oraz senator, 1940-1946 przebywał w USA jako profesor uniwersytecki, od 1947 r. ponownie prof. Politechniki Warszawskiej, 1955-1960 dyrektor Instytutu Chemii Fizycznej PAN. Świętosławski Wojciech Alojzy, w: Kto byt kim, s. 72.

${ }^{183}$ Zob. w niniejszej publikacji: J. Wołczański, Korespondencja abp. Józefa Teodorowicza z abp. Adamem Stefanem Sapieha, dokument 103.

${ }^{184}$ Niem.: chwała Hitlerowi.

a Tekst pisany maszynowo na dwóch stronicach papieru formatu A4. U dołu ostatniej stronicy odręczny nieczytelny autograf pisany czarnym atramentem. 
Otrzymawszy przed chwilą pocztą lotniczą cenne Jego pismo z dnia 17 b.m. odpisujemy o[d]wrotnie - a piszemy po prostu to co myślimy, bez oglądania się na jakiekolwiek względy uboczne. Gdyby Jego Ekscelencja ujrzał w obecnej chwili u boku swego Pana Profesora sądzimy, iż byłby naprawdę szczęśliwy - gdybyśmy się zaś zapytali J[ego] Ekscelencji co odpisać Panu Profesorowi na tak łaskawą gotowość Jego, kto wie, czy nie popadłby w skrupuły odnośnie do wielkiego trudu, dalekiej podróży, znacznych kosztów jakie by ten przyjazd za sobą pociągnął i czy w następstwie tego nie uczyniłby ofiary z tak ważnego dla siebie momentu jakim byłoby przybycie Pana Profesora. Dlatego odpisujemy na łaskawą propozycję Pana Profesora bez uprzedniego odniesienia się do J[ego] Ekscelencji po prostu tak, jak uważamy w sumieniu: proszę pójść za natchnieniem, które niezawodnie z góry przyszło Panu Profesorowi i proszę tu przybyć. Przyjazd Pana Profesora spieszącego sam od siebie jako przyjaciel do łoża chorego przyjaciela byłby niezawodnie momentem niezmiernego znaczenia i kto wie, czy by nie zaważył na szali.

J[ego] Ekscelencja choruje już siódmy tydzień. Choć serce się nieco poprawiło po 10-ciu iniekcjach Strophantiny, jednak dotychczas mięsień za słaby jeszcze by pompować wodę. Stosowano dotychczas Novurit dwukrotnie, Sarylgan trzykrotnie z małym stosunkowo rezultatem (odchodziło najwyżej 2 l[itry] moczu). Dziś na usilne żądanie chorego zrobiono punkcję trwającą około 30 minut. Płynu poszło 1080 gr. Drugie tyle jeszcze zalega. Wątroba znacznie powiększona (jakie[śs 5 palców). Na ogół organizm dotychczas słabo reaguje na stosowane środki.

Zdajemy sobie dokładnie $\mathrm{z}$ tego sprawę, jak w tym wypadku ważnym czynnikiem jest psychiczne nastawienie chorego. $\mathrm{Z}$ początku nie liczono się z tym dosyć. Odkąd jednak do ordynujących lekarzy wszedł jako naczelny kierownik Prof. Rencki ${ }^{185}$ (2 XI), samopoczucie chorego znacznie się poprawiło. Bywały bowiem czasy wielkiej depresji i całkowitej apatii, zwłaszcza gdy chory zażywał Digitalinę (3 razy dziennie po 5 kropel). Poza tym leczą J[ego] Ekscelencję Prof. Czernecki ${ }^{186}$, Dr Falkiewicz ${ }^{187}$, Dr Mądry ${ }^{188}$ (lekarz domowy) i Prof. Laskowicki ${ }^{189}$ (urolog).

${ }^{185}$ Rencki Roman (1867-1941), od 1905 r. pracował w Klinice Powszechnej we Lwowie, w 1920 r. mianowany prof. zwyczajnym patologii i terapii chorób wewnętrznych Wydziału Lekarskiego UJK i dyrektorem Kliniki Chorób Wewnętrznych UJK, w roku akad. 1924/25 i 1925/26 dziekan Wydziału Lekarskiego, kawaler krzyża komadorskiego orderu Odrodzenia Polski, odznaczony Złotym Krzyżem Zasługi, członek korespondencyjny PAU. W. Wojtkiewicz-Rok, Klinika Chorób Wewnętrznych Uniwersytetu Lwowskiego w latach 1897-1939: w setna rocznicę utworzenia Wydziatu Lekarskiego (1894-1994), MNo, 1994, nr 1/2, s. 69-89.

186 Zob. w niniejszej publikacji: J. Wołczański, Korespondencja abp. Józefa Teodorowicza z abp. Andrzejem Szeptyckim, dokument 24.

187 Falkiewicz Antoni (1901-1977), dr nauk medycznych, 1926-1930 młodszy asystent, 1930-1935 starszy asystent I i II Kliniki Chorób Wewnętrznych we Lwowie, 1935-1939 prymariusz Oddziału Wewnętrznego Państwowego Szpitala Powszechnego we Lwowie, w 1943 r. w ramach ekspatriacji osiadł na Rzeszowszczyźnie, w czasie II wojny światowej uzyskał habilitację w Lublinie, od 1945 r. ordynator II Kliniki Chorób Wewnętrznych we Wrocławiu, 1946-1971 prof. kardiologii Akademii Medycznej tamże, w roku akad. 1949/50 dziekan Wydziału Lekarskiego, 1954-1957 rektor uczelni tamże. W. Wojtkiewicz-Rok, Klinika Chorób Wewnętrznych Uniwersytetu Lwowskiego w latach 1897-1939: w setna roznicę utworzenia Wydziatu Lekarskiego (1894-1994), MNo, 1994, nr 1/2, s. 84.

${ }_{188}$ Osoba niezidentyfikowana.

189 Właściwie: Laskownicki Stanisław (1892-1978), absolwent studiów medycznych, uczestnik obrony Lwowa 1918/1919, 1920 r. - pracownik Kliniki Chirurgicznej Uniwersytetu Jana Kazimierza we Lwowie, w 1928 r. habilitacja, docent chirurgii dróg moczowych, prof. tytularny w 1938 r., 1928-1939 ordynator Oddziału 
Jesteśmy z całym uznaniem dla wiedzy, starań i umiejętności fachowych tylu lekarzy - mimo to jednak grono [osób] najbliższych J[ego] Ekscelencji pragnęło najgoręcej dla własnego spokoju i dobra chorego, by jakaś znamienita osobistość lekarska od zewnątrz, znająca bliżej osobę Jego Ekscelencji oraz Jego organizm zbadała stan chorego i wydała orzeczenie swoje. Nie było jednak możliwym przedsięwziąć jakikolwiek krok $\mathrm{w}$ tym kierunku z obawy, by nie urazić tutejszych lekarzy.

Przyjazd Pana Profesora jako przyjaciela do przyjaciela byłby najprostszym rozwiązaniem sprawy, przechodzącym to wszystko, o czym mogliśmy marzyć dla Jego Ekscelencji.

Kreślimy się z wyrazami głębokiego poważania i prawdziwej wdzięczności

Sekretariat Jego Ekscelencji

Najdostojniejszego Ks. Arcybiskupa

Dr. J[ózefa] Teodorowicza

Lwów

[ul.] Ormiańska 7

\section{Dokument 62}

Oryg.: APANP, sygn. P III - 116, teczka 86, Notatka abp. Józefa Teodorowicza dla prof. Stefana Dąbrowskiego, [Lwów br].

Ist ${ }^{\mathrm{a}}$ Konnersreuth Betrug? Antwort auf Dr. Deutschs offenen Brief "Wie steht's um Konnersreuth?" unter Mitwirkung von Theologen herausgegeben von Dr med. Peter Radlo.

${ }^{\mathrm{b}-\mathrm{Na}}$ ostatniej stronicy:-b II Teil. Paradoxer Metabolismus bearbeitet vom Direktor des chemiach-physiologischen Institutes der medizinischen Fakultät an der Universität Posen Professor Dr Stefan Dąbrowski.

\section{Dokument 63}

Oryg.: APANP, sygn. P III - 116, teczka 86, Notatka abp. Józefa Teodorowicza dla prof. Stefana Dąbrowskiego, [Lwów br].

In $^{\mathrm{a}}$ dieser meiner Begutachtung mőchte ich keineswegs schlecht verstanden warden. Ich mőchte nämlich nicht den Anschein erwecken, als ob meine Worte eine, wenn auch

Urologicznego Państwowego Szpitala Powszechnego we Lwowie; w ramach ekspatriacji osiadł w Warszawie: 1943-1944 ordynator oddziału urologicznego Szpitala Ubezpieczalni Społecznej w Warszawie, 1945-1948 przebywał w Krakowie, 1948-1950 kierownik Katedry i Kliniki Urologii Wydziału Lekarskiego Uniwersytetu Warszawskiego, 1950-1962 kierownik Katedry i Kliniki Urologii Akademii Medycznej w Krakowie. J. Leńko, Prof. dr wszechnauk lekarskich Stanisław Laskownicki - jeden z twórców urologii polskiej, UP, 1991, nr 44, s. 3.

a Tekst pisany maszynowo z wyjątkiem zaznaczonej noty. Brak autografu nadawcy.

b-b Nota ręką abp. J. Teodorowicza czarnym atramentem.

a Tekst pisany maszynowo z wyjątkiem zaznaczonej noty. Brak autografu nadawcy. 
verborgene Kritik der gegenwärtigen Stellungnahme des Ordinariates enthielten. Diese Stellungnahme ist nämlich von der durch mich so betonen früheren Stellungnahme in dieser Hinsicht verschieden, dass sich das Ordinariat später bereit erklärte, Therese wiederholten Beobachtungen zu unterziehen.

Die Kirche war stehts in solchen Fällen zu übertriebenes Vorsicht geneigt und ging im derselbeneher eher zu weit, als dass sie den Vorwurf der Leichtgläubichkeit auf sich ziehen mőchte. Als nun demnach Stimmen einiger Aerzte laut wurden, welche sich für die Wiederholung der Untersuchungen erklärten, war das Regensburger Ordinariat bereit, auf darauf einzugehen. Und dies ist verständlich und im Geiste der angenommenen Versichtsmassregeln ganz erklärbar. Aber anderseits dürfen aus dieser Stellungnahme des Ordinariats keine falschen Schlüsse gezogen warden, den diese Stellungnahme ist keineswegs durch des Ueberzeugung von der Irrtümlichkeit des früheren ärzlichen Parere diktiert worden, sie mőchte vielmehr jeder Forderung Genüge leisten. Was das Ordinariat jestzt fordert, das liegt nicht mehr im Bereich wissenschaftlicher Postulate, denen bereits Genüge geleistet wurde, vielmehr sind die neusen diesbezüglichen $\mathrm{Zu}$ geständnisse nu rein Ausdruck der Bereitwilligkeit der Kirche, sogar die Grenze und Rahmen der streng wissenschaflichen Postulate zu überschreiten, kurz und gut sogar viel weiter zu gehen, als die strengsten Forschungen es erfordern kőnnten.

In diesem Geiste wird auch meine gegenwärtige Untersuchung geführt ${ }^{\mathrm{b}}$.

\section{Dokument 64}

Oryg.: APANP, sygn. P III - 116, teczka 86, Notatka abp. Józefa Teodorowicza dla prof. Stefana Dąbrowskiego, [Lwów br].

$\mathrm{Co}^{\mathrm{a}}$ do kwestii dwóch tygodni, to ją najpierw poruszył Hohn - Der Gerade Weg, Das Parere des Dr. Hohn verőffentlicht v[on] Dr. Gerlich ${ }^{190}$, Dezember 1932: „Da Dr. Deutsch bei einer erneuten Beobachtung der Stigmatisierten eine Dauer von vier Wochen verlangt, so ware hier noch zunächst ein Wort am Plantz über die fünfzehntätige Dauer der Schwersternbeobachtung. Das Ordinariat von Regensburg ist nach Anhőrung von Sachverständigen mit dieser Zeit einverstanden gewesen. Hervorragende Aerzte mit hanz anderen Weltanschauung die in die Aufzeichnungen der Schwestern kritisch

b Przypis ręką abp. J. Teodorowicza: „Vide J. Teodorowicz, «Konnersreuth im Lichte der Mystik Und Psychologie», s. 343".

a Tekst pisany maszynowo z wyjątkiem zaznaczonej noty. Brak autografu nadawcy.

190 Gerlich Albert Fritz (1883-1934), urodzony w niemieckiej rodzinie kalwińskiej niemiecki dziennikarz i archiwista, opozycjonista względem III Rzeszy Niemieckiej, dr filozofii, 1920-1928 redaktor naczelny periodyku „Münchner Neuesten Nachrichten”, 1932-1933 redaktor naczelny pisma „Der gerade Weg”; w 1927 r. poznał niemiecką stygmatyczkę z Konnersreuth Teresę Neumann, po czym w 1931 r. dokonał konwersji na katolicyzm. Aresztowany w 1933 r. przez faszystów został osadzony w Dachau, gdzie 30 VI 1934 r. zamordowano go. Autor m.in.: Die stigmatisierte Therese Neumann von Konnersreuth (Bd. 1-2, München 1929), Der Kampf um die Glaubwürdigkeit der Therese Neumann. Eine Auseinandersetzung mit den Professoren Wunderle und Mager (München 1931). K. O. von Aretin, Gerlich Albert Fritz, w: NDB, Bd. 6, red. zbior., Berlin 1963, s. 307-308. 
Einblick nahmen, kommen za einem von Deutsch vőllig verschiedenen Ergebnis. Das Tegebuch der Schwestern war nach Ewald Gewissenhaftigkeit Genauigkeit mit Unvoreigenommenheit und nüchternem Urteil geführt"191.

Mimo to umieściłem w mej książce następujący ustęp: „Dessenungeachtet stelle ich mich in meinem Ausführungen theoretisch auf den Standpunkt, als ob diese zwei Wochen eine zu kurze und unenügende Frist bildeten und als ob eine Längere Untersuchung diesbezủglich angezeigt wäre. In diesem Geiste wird dieses Problem von mir noch einmal erwogen"192.

\section{Dokument 65}

Oryg.: APANP, sygn. P III - 116, teczka 86, Telegram abp. Józefa Teodorowicza do prof. Stefana Dąbrowskiego, Lwów [br.]

Telegram $^{\mathrm{a}}$ Nr 388

rp 10

poseł Dąbrowski Uniwersytet Poznań[ski]

Lwów 8+388 12513

Gorące modły we mszy (jaki stan) Teodorowicz.

\section{Dokument 66}

Oryg.: AFKDOPW, teczka 139: Spuścizna abp. Józefa Teodorowicza, sygn. 1308/365 [5], Telegram prof. Stefana Dąbrowskiego do abp. Józefa Teodorowicza, Poznań 10 V 193[...].

Telegram $^{\mathrm{a}} \mathrm{Nr} 62$

Przyjęto dn[ia] 10/5 193[... $]^{\mathrm{b}}$

Godz. 17 min[ut] 50

elt excelencja ks. arcybiskup teodorowicz lwow

poznan 3 , dworzec $109,-23,-10 / 5,-17,-20$

wysylam obszerniejsza odpowiedz na telegram goraco odradzam wszelki pospiech publikacji zwlaszcza wobec najnowszych prac francuskich angielskich = dabrowski.

191 Przypis ręką abp. J. Teodorowicza: „Vide J. Teodorowicz, «Konnersreuth im Lichte der Mystik Und Psychologie», s. 342".

192 Przypis ręką abp. J. Teodorowicza: „Vide J. Teodorowicz, «Konnersreuth im Lichte der Mystik Und Psychologie», s. 343-344".

a Tekst maszynowy na formularzu pocztowym.

a Tekst bez znaków diakrytycznych na formularzu telegramu pocztowego. Zachowano pisownię zgodną z oryginałem.

b Brak tekstu. 


\section{Dokument 67}

Oryg.: AFKDOPW, teczka 139: Spuścizna abp. Józefa Teodorowicza, sygn. 832/262 [7], List prof. Stefana Dąbrowskiego do abp. Józefa Teodorowicza, Poznań bd.

Ekscelencjo ${ }^{a}$, Ks. Arcybiskupie,

Poznań, środa

Pozwalam sobie przesłać recenzję Jego przemówienia, zamieszczoną w „Kur[ierze] Pozn[ańskim]”. Nadto miałem sposobność widzieć się z Ks. Senatorem Prądzyńskim ${ }^{193}$, a to w celu omówienia nowego sposobu wydawania „Żywota Chrystusa Pana”. Uprzedził mię, że p[an] Jeleński tylko wówczas zgodzi się na ten sposób, jeżeli każdy tomik będzie mógł stanowić całość w sobie i jeżeli rękopis takiej całości będzie w posiadaniu drukarni. Zdaje mi się, że jego żądania są słuszne i uzasadnione.

Dodaję, że paczkę podziękowań rozesłałem. Jednakże mam jeszcze 9 kopert bez niczego, bez podziękowań drukowanych. Może zatem Ks. Arcybiskup wyda polecenie, aby przysłano mi te podziękowania żądając, by na przyszłość nie popełniono konfuzji!

Łączę wyrazy głębokiej czci i synowskiego oddania

Stefan Dąbrowski

PS. Zaniepokojona i zdziwiona opinia Wielkopolski wizytą Ks. Metropolity Sapiehy w Belwederze i to wkrótce po obronie Ks. Kardynała Kakowskiego ${ }^{194}$ zaczyna się uspokajać wiadomością „Kur[iera] Pozn[ańskiego]”, że Książę Metropolita złożył wizytę Panu Prezydentowi Rz[ecz]p[ospoli]tej, a w Belwederze u p[ana] Prezesa Rady Ministrów był z jego inicjatywy.

S[tefan] D[ąbrowski]

a Tekst pisany czarnym atramentem na 2,5 stronicy papieru formatu A4.

193 Prądzyński Józef (1877-1942), święcenia kapłańskie w 1901 r. w Poznaniu, 1902-1912 wikariusz par. Strzelno na Kujawach, 1912-1917 proboszcz par. pw. św. Michała w Gnieźnie, działacz Stronnictwa Narodowego i Obozu Wielkiej Polski, 1926-1939 senator RP, działacz katolicko-społeczny, duszpasterz akademicki Uniwersytetu poznańskiego, podczas II wojny światowej działał w nurcie polskiego podziemia. G. M[azur], Prądzyński Józef, w: Kto byt kim, s. 540.

${ }_{194}$ Zob. w niniejszej publikacji: J. Wołczański, Listy abp. Józefa Teodorowicza do abp. Józefa Bilczewskiego, dokument 94. 